Florida International University FIU Digital Commons

3-30-2012

\title{
The Sacred Nature of the Akan Chief and its Implications for Tradition, Modernity and Religious Human Rights in Ghana
}

Seth Tweneboah

Florida International University, stwen001@fiu.edu

DOI: $10.25148 /$ etd.FI12050127

Follow this and additional works at: https://digitalcommons.fiu.edu/etd

\section{Recommended Citation}

Tweneboah, Seth, "The Sacred Nature of the Akan Chief and its Implications for Tradition, Modernity and Religious Human Rights in Ghana" (2012). FIU Electronic Theses and Dissertations. 590.

https://digitalcommons.fiu.edu/etd/590 


\title{
FLORIDA INTERNATIONAL UNIVERSITY
}

Miami, Florida

\section{THE SACRED NATURE OF THE AKAN CHIEF AND ITS IMPLICATIONS FOR TRADITION, MODERNITY AND RELIGIOUS HUMAN RIGHTS IN GHANA}

\author{
A thesis submitted in partial fulfillment of the \\ requirements for the degree of \\ MASTER OF ARTS \\ in \\ RELIGIOUS STUDIES
}

by

Seth Tweneboah 
To: Dean Kenneth G. Furton

College of Arts and Sciences

This thesis, written by Seth Tweneboah, and entitled The Sacred Nature of the Akan Chief and its Implications for Tradition, Modernity and Religious Human Rights in Ghana, having been approved in respect to style and intellectual content, is referred to you for judgment.

We have read this thesis and recommend that it be approved.

Whitney Bauman

Christine Gudorf

Albert Kafui Wuaku, Major Professor

Date of Defense: March 30, 2012

The thesis of Seth Tweneboah is approved.

Dean Kenneth G. Furton

College of Arts and Sciences

Dean Lakshmi N. Reddi

University Graduate School

Florida International University, 2012 
(C) Copyright 2012 by Seth Tweneboah All rights reserved. 


\section{DEDICATION}

This thesis is dedicated to the chiefs and peace loving people of "Akan Traditional Area." 


\section{ACKNOWLEDGMENTS}

I was first introduced to religious human rights as an overarching concept especially in contemporary international political discourse when, as part of my national service, I served as a teaching assistant under Rev. Dr. Abamfo Atiemo, at the Department for the study of Religions, University of Ghana, Legon. He was by then doing his $\mathrm{PhD}$ in this field. Since then, it has become customary for me to delineate the interface between religio-cultural practices and sociopolitical issues and how the former is implicated in the latter especially in traditional societies. The present work is part of this interest.

This interest could not have been pursued without the special interest shown by my supervisors: Dr. Albert Kafui Wuaku, Prof. Christine Gudorf and Dr. Whitney Bauman. I wish especially to thank Dr. Albert Wuaku who did not only serve as my major professor of this thesis but, before and throughout my studies in FIU, has been a brother, a friend and a mentor. He constantly pushed and pulled me towards the right academic path. His expertise in indigenous Ghanaian traditions made it possible to constantly help reshape some of my theories and supporting evidence.

Prof. Christine Gudorf, besides serving as my supervisor, has always made sure my stay here in the Miami becomes a memorable one. Her financial and motherly support cannot be adequately described in this work. She was always conscious of the ethical dimension of the work.

Dr. Whitney Bauman has been a friendly supervisor and a great source of encouragement and hope. His insistence on conceptual framework throughout his lectures and supervision of this thesis gave him the opportunity to drill me on my choice of theories and theorists. 
I am especially indebted to the staff and member of the Department of Religious Studies in the Florida International University, Miami, especially Professors Erik Larson and Oren Baruch Stier, for granting me the opportunity of studying in their department. Special thanks are especially due to Dr. Harrison Kimberly, Director of Undergraduate Writing Program, and her colleagues at the English Department of the same university who agreed not only to fund my sponsorship but to also give me the needed training necessary to be their graduate assistant. I truly enjoyed the good coaching given to me and the cordial relations that existed between me and Tania Lopez, Andrew Golden, Mike Creeden, Nicholas Vagnoni and Patricia Warman and the entire English Department faculty members at FIU. During those semesters that I served as their graduate assistant, they did not only serve as my supervisors but also motivated and mentored me towards the right path.

My debt of gratitude is due to Rev. Prof. Elom Dovlo, Director of Adult Education, University of Ghana, Legon, through whose contact I got to know Dr. Wuaku, who pitched me into the MA program at the Florida International University, Miami.

I am particularly grateful to Mrs. Alice Agyemang of Atlanta, Georgia, and her husband, Mr. Samuel Agyemang, who became my parents in the Diaspora. No amount of words will be enough than to say "May God bless their family."

I wish to pay my homage and show reverence to the sacred chiefs and elders of the indigenous Akan societies. This study would have been unthinkable but for their formidable resistance to the decadence of modernity and firm opposition to the fossilization of their sacred office. While the intention of this study was not to indict, implicate or treat their sacred office with disrespect, certain inevitable academic criticism and critique of some aspects (historical or contemporary) of the chief's office was essentially unavoidable. Similarly, analysis, opinions, 
and seeming defense of some aspects of the chieftaincy institution are purely academic and must not be read or interpreted as an apologetic treatment of the institution. While the thoughts in this study must reflect my belief in the chieftaincy institution, the genre - academic critique of human rights issues - required an unbiased revelation of the "truth." I was consciously aware that the office of the chief and his elders still receives the necessary reverence and obeisance due the ancestors. In view of this, certain choice of words that would otherwise have traditionally, attracted sanctions, emotive response or disapproval (scorn or looks of dissatisfaction) must be given only academic connotations.

Every knowledge and idea borrowed from various experts have been duly acknowledged especially in the footnotes and bibliography. This notwithstanding, I wish to extend my gratitude to all such pacesetters and experts for taking the lead for some of us to follow. 


\begin{abstract}
OF THE THESIS
THE SACRED NATURE OF THE AKAN CHIEF AND ITS IMPLICATIONS FOR TRADITION, MODERNITY AND RELIGIOUS HUMAN RIGHTS IN GHANA
\end{abstract}

by

\author{
Seth Tweneboah \\ Florida International University, 2012 \\ Miami, Florida \\ Professor Albert Wuaku, Major Professor
}

This study explored the interface between the abuses inherent in the sacred nature of the Akan (a Ghanaian ethnic group) Chief and international human rights laws. It argued that the sacred basis of Akan Chieftaincy, which empowers and legitimizes Akan Chiefs, also leads to them imposing restrictions on the rights of their subjects. The study examined the implications of these restrictions in the light of a rapidly modernizing, thoroughly globalizing, and a religiously pluralistic Ghana where the influence of western originated belief in individual rights is growing. The study also explored why, in spite of the many existing Constitutional and legal provisions in Ghana, breaches of religious freedom still occur. It shed considerable light on how agents of the modern state and the Chiefs, connive to sometimes suppress the rights of individuals. The study identified the implications of this development for policymaking in Ghanaian communities where modernity and tradition co-exist. 


\section{TABLE OF CONTENTS}

CHAPTER

PAGE

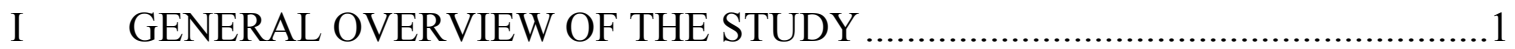

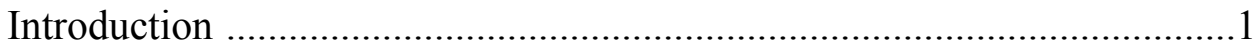

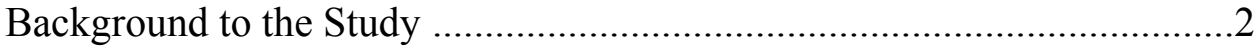

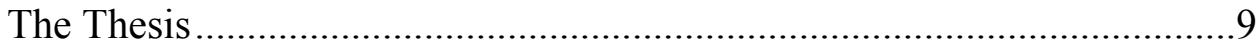

Frames of Conceptualization ................................................................10

Clarification of Terms .....................................................................14

Chief, King and Queenmother ...................................................14

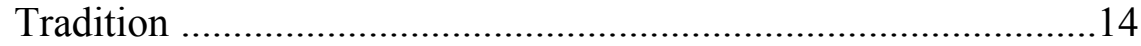

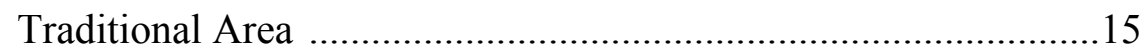

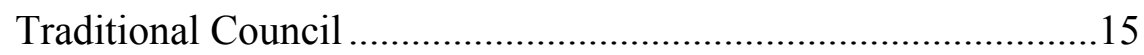

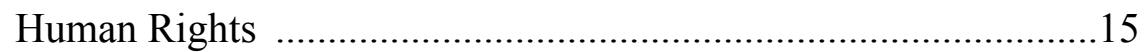

Religious Human Rights ............................................................16

Religious Pluralism ................................................................ 17

Design and Instrumentation .................................................................17

The Setting: Locating the Akan ..................................................................17

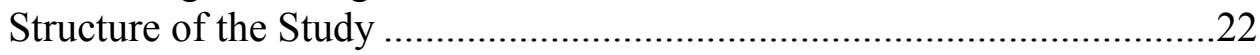

II EXPLORING THE CONCEPTUAL FRAMEWORK ……………………........25

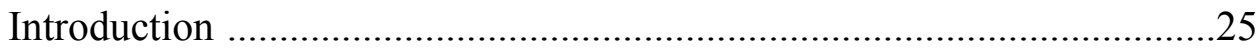

Chieftaincy and the Concept of the Sacred..............................................25

Chieftaincy as a Cultural Symbol ..........................................................29

Hegemony and Chieftaincy Institution ...................................................33

The Sacred, Hegemony and Human Rights .............................................39

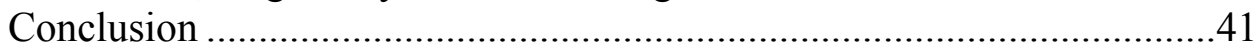

III THE RELIGIOUS FOUNDATION OF THE AKAN CHIEFTAINCY

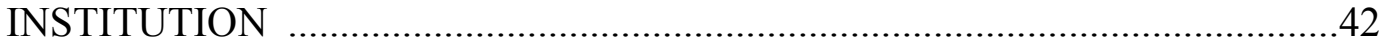

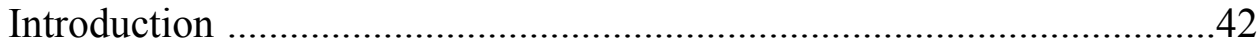

Indigenous Akan Religion .................................................................42

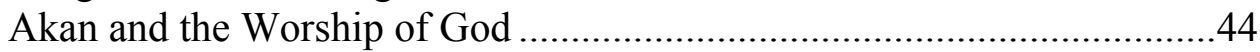

The Gods and the Moral Community …………………….......................46

The Place of the Ancestors …………………………...........................48

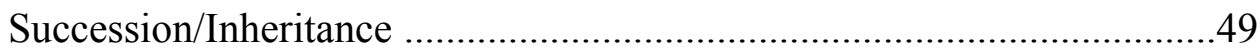

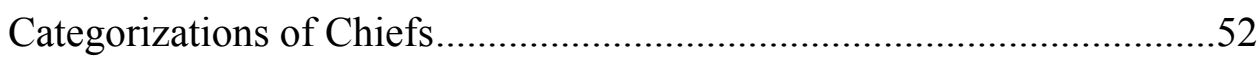

The Paramount Chief (Omanhene) ………………………...........52

The Queenmother and her Role .....................................................53

The Divisional Chiefs (Abrempong/Abremponfo) ..........................59

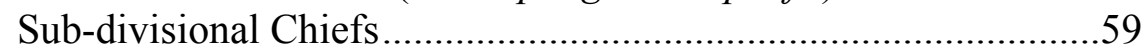

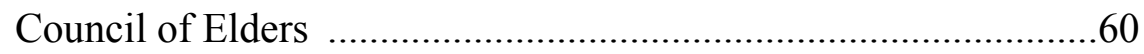

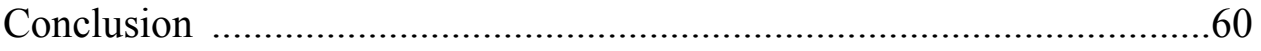


IV THE METAPHORS OF THE AKAN CHIEF ………...................................61

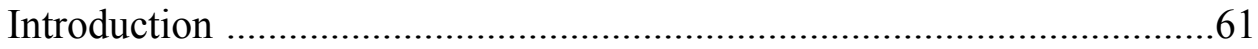

The Sacralization of the Akan Chief..........................................................61

Disability Taboos and Akan Chieftaincy Institution ..................................67

The Stool as a Symbol of the Chief's Authority..........................................72

The Nkonwafieso (Stool Room as a Sacred Space.....................................82

The Role of the Chief..............................................................................86

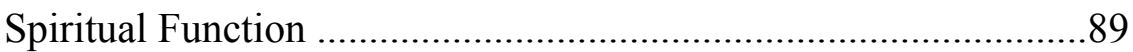

Destoolment of Akan Chief ....................................................................99

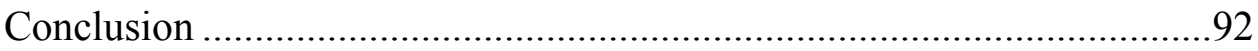

$\mathrm{V}$ CHIEFTAINCY AND THE IMPACT OF COLONIALISM AND

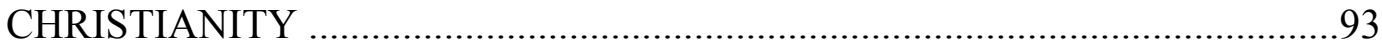

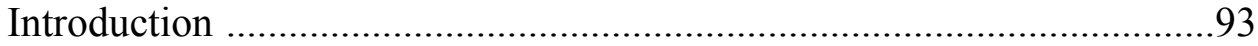

Akan Chieftaincy and the Colonial Administration ..................................94

Chieftaincy and Plurality of Religion .................................................102

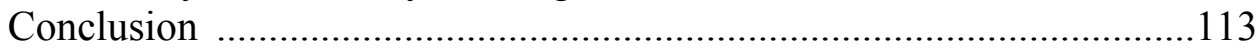

VI CHIEFTAINCY, MODERNIZATION AND GLOBALIZATION ....................114

Introduction ..................................................................................114

Modernization and its Effects on the Power of the Akan Chief ...............114

Western Education and the Sacred Authority of the Chief.......................125

Chieftaincy and Post-Independence Struggles .......................................128

Globalization and its Impact on Local Cultures ………….....................135

Detribalization of the Indigenous Societies .............................................136

Technological Advancement and Local Cultures ...................................137

Conclusion ...................................................................................140

VII CHIEFTAINCY AND HUMAN RIGHTS: ISSUES OF CONCERN ............141

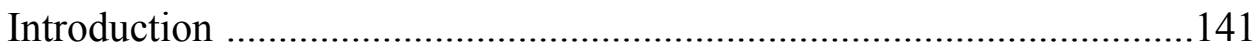

Desacralization of the Position of the Akan Chief ...................................141

The Chief as an Ally of the Government ..............................................143

Chieftaincy and Democratization of Tradition ……………………........148

The Chief as Official Representatives of the Land? .................................153

Issues of Concern for Policy Implication................................................156

Sale of Land Reforms ............................................................159

Program of Succession Plan.........................................................160

Education of Chiefs....................................................................163

Progressive Study of Chieftaincy Affairs …………………….....162

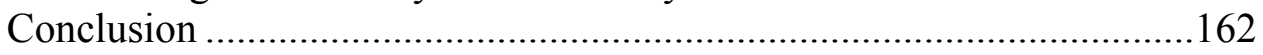

VIII SUMMARY, SIGNIFICANCE AND CONCLUSION ………………….........166

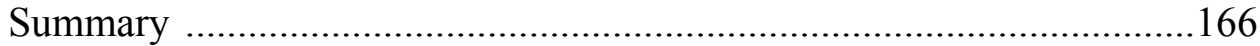

Significance of the Study ......................................................................167

Limitations and Suggestions for Future Research ……...........................170

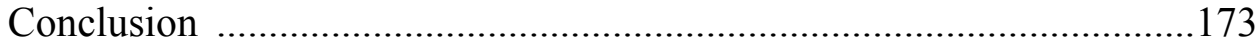

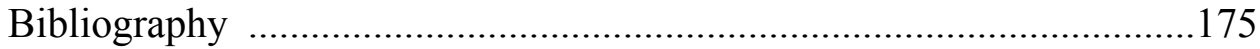




\section{CHAPTER I: GENERAL OVERVIEW OF THE STUDY}

\subsection{Introduction}

Traditionally, a chief in a Ghanaian community is the political leader of the ethno-tribal group. Because the political and the religious landscape are enmeshed in African indigenous cultures, the basis of the chief's political authority is religion. Among the Akan of Ghana, a chief is a sacred person. He sits on a throne or stool that has been used by previous chiefs. The stool links a chief with the spirits of the departed chiefs upon whom the welfare of the community depends. The Akan chief then is the intermediary between the material and spiritual universe. Traditionally, according to Rattray, ${ }^{1}$ Busia, ${ }^{2}$ Sarpong, ${ }^{3}$ Kwesi Yankah, ${ }^{4}$ etc, challenging the chief amounts to challenging the ancestors of the land. Challenging the chief has, over the years, been considered a treasonable offence. As such, in many Akan traditional societies, such challengers of the chief have been considered as deviants and have been subjected to a variety of sanctions. The study sought to argue that the sacredness associated with traditional Akan chief in Ghana has given them so much authority that, in most cases, they engage in actions that challenge the full realization of international human rights laws.

\footnotetext{
${ }^{1}$ R. S. Rattray, Ashanti Law and Constitution (Oxford: The Clarendon Press, 1929).

${ }^{2}$ K. A. Busia, The Position of the Chief in the Modern Political System of Ashanti: A Study of the Influence of Contemporary Social Changes on Ashanti Political Institutions. (London: Frank Cass and Co. Ltd., 1968).

${ }^{3}$ Peter Sarpong, The Sacred Stool of the Akan (Accra: Ghana Publishing Corporation, 1971).

${ }^{4}$ Kwesi Yankah, Speaking for the Chief: Okyeame and the Politics of Akan Royal Oratory (Bloomington \& Indianapolis: Indiana University Press, 1995).
} 


\subsection{Background to the Research}

The Akan chieftaincy institution has been a struggling institution since the advent of colonial invaders in the fifteenth century. Although the chieftaincy institution occupies an important religio-political place of the society, today, the office seems to be irrelevant to some people. From the period of colonialism to the present era, the institution has been battling with a host of factors - colonialism, modernity, globalization and religious pluralism, among others for its survival. These forces have undermined the basis of the sacrality and authority of the chief. The study explored the human rights implications of the chief's response to that predicament in relation to his treatment of his subjects.

It also equally interesting to add that the encounter between the people of Africa and the early European colonizers has been described by some observes as the cause of the black man's burden and a curse to the continent. ${ }^{5}$ The indigenous political institution, during colonial period was coerced into the dictates of the colonial administration. David Basil, for example, has

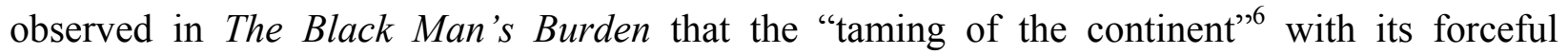
imposition of nation states (patterned in western models of governance) which hijacked the hitherto sacred traditional states, among other determinants, was a burden and a curse to traditional African societies. I must add that this encounter has been a double curse for the indigenous political structures and leaders of the continent. First, particularly in the context of British West Africa, the early colonizers who became fascinated by the unlimited control and influence of the chief, decided to make the institution as an essential part of their administration.

\footnotetext{
${ }^{5}$ Basil Davidson, The Black Man's Burden: Africa and the Curse of the Nation-State (New York: Times Books, 1992).

${ }^{6}$ Davidson, The Black Man's Burden, 78.
} 
According to Richard Rathbone, the colonial government, overwhelmed by the command and influence the chief wielded, "concluded that they could only rule the Gold Coast effectively with the assistance of the country's traditional rulers." ${ }^{, 7}$ In the political philosophy of the colonizers, Rathbone concluded, "chiefly power was the best and, almost certainly, the only guarantee of what the British deemed to be law and order." ${ }^{8}$ The idea behind all this incorporation was to also make sure that "native institutions and sensitivities were being respected and minimally interfered with." ${ }^{\prime 9}$ The said move introduced a dual system of authority under one political system - the authority of the colonial government on the one hand, and the authority of the chief and his elders, on the other. However, beneath this dual system of authority was an economic motif. The colonizers' recognition of the power of the chief was, to a larger extent, economically motivated. As Rathbone has again noted, the indigenous rulers of the society, especially in what was then called Gold Coast (now Ghana), were seen as "the centres of economic power controlling, as they claimed to do, access to land and the people who worked on that land." ${ }^{10}$ It is interesting to add that the use of the chief by the colonizers was motivated by the fact that he was seen as an effective means of tax and other revenue collection and exploitation by the colonizers.

The colonial encounter, however, brought about the limitation of the chief's power which resulted in constant confrontation with the local subjects and the colonial powers. The colonial intervention dispossessed the chief of some sanctions which hitherto had been his sole preserve.

\footnotetext{
${ }^{7}$ Richard Rathbone, Nkrumah \& Chiefs: Politics Of Chieftaincy In Ghana 1951-1960, First. (Athens: Ohio University Press, 2000), 10.

${ }^{8}$ Rathbone, Nkrumah \& Chiefs, 10.

${ }^{9}$ Rathbone, Nkrumah \& Chiefs, 11.

${ }^{10}$ Rathbone, Nkrumah \& Chiefs, 10.
} 
The limitation of such powers, to a larger extend, gave uncensored powers to the common people who were able to challenge the chief's authority. For example, according to Rathbone, within a period of twelve years, between 1904 and 1926, over 109 destoolment cases were recorded in Akanlands alone,${ }^{11}$ something that was less heard of previously.

Again, a defiant and anti-colonial chief was, on several occasions, humiliated before his subjects. The colonial rulers also extended their control over the judicial and other powers which the chief had previously enjoyed. The encounter opened new challenges to the power and the sacred nature of the chief. If the fascination with the tribal chief which led to the decision to rule through the indigenous is a curse, then the second most important curse brought about by the colonial intervention was the resulting challenges of chiefly power within the tribe. Much emphasis will be laid on this in subsequent discussions. However, it must be said that colonialism opened the indigenous society to a host of modernizing factors which, in turn, served as a challenge to the authority of the chief.

The chieftaincy institution has also been challenged by, and has reacted to the effects of globalization. With globalization came an increase in global economic, social, cultural, technological, political, ecological, etc, connectivity and integration. Societies, especially nationstates have become "progressively less sovereign than they used to be in terms of control over their own affairs." 12 The coming together of people from diverse cultures, societies, backgrounds, etc, brought about cultural differences which have challenged religious beliefs and traditions within religious practices. Thus, with the coming together of various societies into one global society, the authority of the chief became eroded. The traditional religion over which the

\footnotetext{
${ }^{11}$ Rathbone, Nkrumah \& Chiefs, 13.

${ }^{12}$ Anthony Giddens, "From the Consequences of Modernity," in Colonial Discourse and Post-Colonial Theory: A Reader, ed. Patrick Williams and Laura Chrisman (New York: Columbia University Press, 1994), 182.
} 
chief presides is no longer the official religion of the state. For instance, per the demands of the 1992 Constitution of Ghana, the modern secular state, which supersedes the hitherto sacred traditional state, does not give priority to any one particular religious tradition. All religions are given an equal amount of opportunity to operate. As Abdullahi An-Na'im has pointed out, the modern nation state must be committed to enshrining the religious "neutrality" in its constitution and legal system. ${ }^{13}$ With this in mind, the indigenous religion, which previously enjoyed the exclusive support of the traditional state, is therefore, regarded just like any other religion. ${ }^{14}$ Indeed, the adoption of the modern democratic form of governance, which paved way for religious pluralism, put considerable limitation not only on traditional religions but also on traditional chief's power and privilege. As An-Na'im has observed:

Prevailing conceptions of democracy stipulate that the state should foster religious pluralism without undue preference for a particular religion over others. These conceptions of democracy require religions to sustain themselves and thrive on the cogency and validity of their message to believers without coercion or undue advantage over unbelievers and their beliefs or lifestyles. ${ }^{15}$

Globalization with its attending effects of religious pluralism thus presents a confrontational relationship between the religio-cultural traditions of the society and the individual autonomy that finds expression in modern society. "Cultural-ethnic and religious communities have become acutely aware of the threat to their identities by an engulfing, mainly western driven,

\footnotetext{
${ }^{13}$ Abdullahi Ahmed An-Na'im, "Introduction: Competing Claims to Religious Freedom and Communal SelfDetermination in Africa," in Proselytisation and Communal Self-Determination in Africa, (Maryknoll and New York: Orbis Books, 1999), 4.

${ }^{14}$ Abamfo Ofori Atiemo, "International Human Rights, Religious Pluralism and the Future of Chieftaincy in Ghana," Exchange 35, no. 4 (2006): 372.

${ }^{15}$ An-Na'im, "Introduction," 3-4.
} 
economic globalisation." 16 The individual's concept of what is moral is no longer seen in the context of traditional customs. As Dohrnman W. Byers notes, "The current that is today undermining the theoretical foundations of human rights is not so much 'the growing marginalization of religious belief' as the evolution of secularism itself... They grounded morality not in religion, but in metaphysics." ${ }^{17}$

Part of the challenge is the ongoing confrontational relationship between religious and non-religious dimension of reality. The question that secularity poses to dominant values as Byers asks is "In a world without ultimate meaning, what sense does it make to say that a human being is 'sacred,' 'inviolable,' endowed with 'inherent dignity,' 'an end in himself'?"18 Assuming that those who think like Byers are wrong, ${ }^{19}$ and that all human beings, indeed, possess such supernatural qualities, this argument can then be reframed thus: what is it about other human beings that make them more sacred than others? Thus, contemporary awareness of diverse views about sacrality has paved way for the deconstruction of and a challenge to the sacred authorities of which the Akan chief is a clear example. In this context, the argument has been that the chief could be sacred but if this sacredness is not communicated to the people, he remains unseen and unacknowledged. Only him, the chief, will recognize this "fact." However, the Akan chief is not just a political leader. His presence and the office he occupies evoke

\footnotetext{
${ }^{16}$ Dani Wadada Nabudere "Human Rights and Cultural Diversity in Africa" Paper written for the Association of Law Reform Agencies of Eastern and Southern Africa-(ALRAESA) Conference on the Fusion of Legal Systems and Concepts in Africa, September 4-8th 2005, 1.

${ }^{17}$ Dohrman W. Byers, "The Morality of Human Rights: A Secular Ground” 26, no. 1, Journal of Law and Religion (2011 2010): 2-41.

${ }^{18}$ Byers, "The Morality of Human Rights," 5.

${ }^{19}$ The basis of this argument is found in Michael Perry's argument that human beings deserve rights by virtue of being sacred. See Michael Perry, The Idea of Human Rights: Four Inquiries (Oxford: Oxford University Press, 1998), 13.
} 
different symbols and meanings in the society. One who sees the Akan chief attaches some important symbols which have meaning in the context of the Akan tradition.

Against the background of this symbolic representation of the chief, the chieftaincy institution has been co-opted into modern political structures. In most cases, it has been used as a political springboard for purposes of mobilization of the people. The importance of the chieftaincy institution, among others, is seen in the light of the support they receive from the state and its agents. What makes this issue quite problematic is that the state institutions mandated to protect the rights of the individual in the context of international human rights have also been implicated in the abuses inherent in the sacred nature of the chief. The state agents the political leaders - have been accused of being covert allies of the chief in the perpetuation of dominance of the chief. In their attempt to win power, political parties - politicians in general, to a larger, - collaborate with the chief. Politicians, especially in times of election, try to appropriate and manipulate this powerbase of the chief. They do so because the chief is not only close to the masses but he also has a voice that is easily heard and understood by the people. Thus, the chief is considered as a player in the political game. So far as the modern state is not adequately equipped to satisfactorily deal with all its citizens, members of the traditional society will always be cut from Anthony Giddens' "time-space distanciation. ${ }^{, 20}$ Under such conditions, the power of the chief still becomes relevant in these societies.

Particularly in places that are disconnected from the presence of the central government societies distant from the reach of the agents of the modern nation-state - the chief controls a

\footnotetext{
${ }^{20}$ According to Anthony Giddens, social life consists of face-to-face or remote interactions. The concept of timespace distanciation is used to describe the process whereby this remote interaction has become an ever more significant feature of human life, and through which social systems that were previously distinctive have become connected and interdependent. For a good understanding of "time-space distanciation and the generation of power," see Anthony Giddens, A Contemporary Critique of Historical Materialism, vol. 1 (Berkeley and Los Angeles: University of California Press, 1981), 90-108.
} 
strong powerbase. In the same way, the chief taking advantage of this, also tries to assert his authority in these areas, thus presenting a dual source of authority. What is problematic about this is that though the chief wields power and influence in his territory, absolute control - the chief's sanctioning power in particular, which he hitherto wielded - has been taken over by the leaders of the modern nation state. The judicial powers of the chief, for example, have been taken over by the law courts. Oftentimes, in his attempt to regain and reassert their lost power and privilege, the chief engages in actions that, in the context of globalization and international human rights laws, violate the rights of the defenseless and powerless individuals within the territory of the chief. The violation of citizen's rights in the name of sacrality, indeed, was the concern of this research.

While globalization has led to the loss of sanctioning power of the chief to leaders of the modern nation-state institutions, religious pluralism has challenged the sacrality associated with the office of the chief. Plurality of religion has presented a challenge to traditional views regarding the sacred foundation of the chief's office and promoted the concept of living side by side with many religious traditions which had previously been foreign to the indigenous societies and their leader, the chief. Religious pluralism "in general and the negative evaluation of aspects of chieftaincy by Christian churches in particular, posed a formidable challenge to the institution, especially, in 19th century."21 The proliferation of Pentecostalism, especially in the 1980s, for example, dealt a big blow to the power of the chief. The chieftaincy institution with its ancestral foundation, has oftentimes, been demonized by the teachings of Pentecostals. Because the foundation of the institution is cast as demonic, a new set of chiefs, patterned in the authority of Christ, and not the ancestors, have been created. For some observers, this is the result of the

\footnotetext{
${ }^{21}$ Atiemo, "International Human Rights," 367.
} 
creation of Association of Christian Chiefs ${ }^{22}$ who would distinguish themselves as "the called out ones." This challenge and other activities of Christianity which will be discussed later in the work, have led to a host of reactionary responses from the chief which all have implications for the human rights of the individual.

The point of the discussion thus far, has been that the chief, conscious of the demise of his authority, and in an attempt to make the chieftaincy institution remain viable, often uses customary and religious sanctions, which, in most cases, offend some powerless individuals within his (the chief's) territories. The individual's freedom of speech and worship, in most cases, are affected as a result of the activities of the chief. The question that most people ask is "in the context of democratic and religiously pluralistic society such as Ghana, why should the individual be punished if he or she disregard or does not subscribe to the authority of the chief whose position is founded on traditional religious beliefs which the individual does not share?" This question, indeed, is a very problematic but equally significant concern that needs to be addressed for purposes of peaceful co-existence in a multicultural and transitional society such as Ghana. But others might debate: "Should the values of a society vanish in the name of human rights? "And whose human rights should these traditional values secede to?" These are some of the questions that this study picked up.

\subsection{The Thesis}

The study sought to argue that the sacred position of the Akan chief is a challenge to the full realization and implementation of international human rights laws in Ghana. It engaged some of the implications of the interface between the customs associated with the office and person of the chief and the human rights of the individuals to express themselves in the light of

\footnotetext{
${ }^{22}$ Atiemo, "International Human Rights," 367.
} 
international human rights. In arguing so the research will be guided by the questions: 1) How have the people of Akan traditional societies, over the years, reacted to the sacred position of the Akan chief? and 2) How has the religio-cultural worldview regarding the position of the Akan chief been used as a hegemonic tool and, in turn, affected the religious human rights of the people who live in Akan areas?

\subsection{Frames of Conceptualization}

Traditionally, the Akan chief is the political leader of the Akan group. Because the political and the religious realms are enmeshed in African indigenous cultures, the basis of the chief's political authority is religion. A chief is a sacred entity. He sits on a throne or stool that has been sat upon by chiefs who have passed away and this stool links him with the spirits of the departed upon whom the welfare of the community depends. A chief then is a mediating point of the material and spiritual universe. His office is a sacred one. One can thus, argue that in the sacred office of the chief, there is a fusion of ideology and practice - ideologically, the chief is believed to be the repository of the sacred values of the society. He is the representative of the ancestors of the land who are considered, among other spiritual forces, as the moral law-givers of the society. ${ }^{23}$ This ideology is translated into practice when an individual who challenges the chief's authority is made to face the customary sanctions of the society. In his Ashanti Law and Constitution, for example, R. S. Rattray posits the view that owing to his sacred position, to defame a chief by disrespecting him would be regarded as a tribal taboo. Rattray outlines certain forms of offenses that were considered as tribal taboos. Though such taboos were meant to protect the welfare of the general citizens, they were considered especially grievous when the

\footnotetext{
${ }^{23}$ Kofi Asare Opoku, West African Traditional Religion (Accra: FEP International Privite Limited 1, 1978), $152-$ 166.
} 
victim is the chief or a royal of the state. As such, death sentences were given to such offenders. According to Rattray, the reason for such a sentence was because failure to do so also offends the ancestors (nsamanfos) and "the Samanfo would say, 'Did we put you on this Stool that you should allow us to be spoken to thus?"” ${ }^{24}$ Offenses that attract traditional aso twe (punishment) include insulting the chief (atendidie), ${ }^{25}$ and impertinence (mpoatwa) ${ }^{26}$ refusing to heed to the call of the chief. ${ }^{27}$ An abuse of the chief or what Kwasi Yankah referred to as any "lack of verbal comportment" ${ }^{\text {" } 8}$ in the presence of the chief was "an insinuation against the good sense of his ancestors." ${ }^{29}$ The office of the chief has "an aura of mystical pre-eminence-of the majesty of supreme authority. ${ }^{30}$ As Rattray has observed, challenging the chief means that one has the capacity to challenge the ancestors of the land. In traditional societies, such challengers are considered as deviants. They are branded as amanbofos (from aman, traditional states, $b o$, break/collapse and fos, those/people who) or radical troublemakers of the traditional society and

${ }^{24}$ See Rattray, Ashanti Law and Constitution, 310.

${ }^{25}$ Even today the seriousness of this offense goes beyond traditional to cover a breach of the country's legal code. For example, section 63 (c) of the Chieftaincy Act 2008, (Act 759) makes it clear that a anyone who "knowingly uses disrespectful or insulting language or insults a chief by word or conduct commits an offence and is liable on summary conviction to a fine of not more than two hundred penalty units or to a term of imprisonment of not more than three months or to both and in the case of a continuing offence to a further fine of not more than twenty-five penalty units for each day on which the offence continues."

${ }^{26}$ See Seth Tweneboah, "Religious Human Rights in the Techiman Traditional Area of Modern Ghana" (MPhil Thesis, unpublished: University of Ghana, 2010).

${ }^{27}$ Over the years, this has been a very serious legal bane of contention. Not until September 2011 when the Supreme Court ruled expunging section 63 (d) of 2008 Act 759, it was an offense under the said act to deliberately refuse to honor a call from a chief to attend to an issue. What is interesting about this issue is that though the chiefs have vowed to challenge the ruling, this issue was taken to the court by an ex paramount chief (Nana Adjei Ampofo of Goaso traditional area).

${ }^{28}$ This is how Yankah has appropriately termed any uncensored language in the presence of the chief. See Kwesi Yankah, Free Speech in Traditional Society: The Cultural Foundations of Communication in Contemporary Ghana (Accra: Ghana Universities Press, 1998). In his Speaking for the Chief, Yankah again discussed the seriousness of talking directly to the chief without observing the traditional protocol that demands channeling of all such speeches through the chief's linguist (okyeame) whose duty it is to refine all words to and from the chief.

${ }^{29}$ Rattray, Ashanti Law and Constitution, 310.

${ }^{30}$ Fortes, Kinship and the Social Order, 142. 
are made to undergo the necessary traditional "ear pulling" (aso twe). ${ }^{31}$ What is worrying is that most of these sanctions, in the context of international human rights, are considered as torture ${ }^{32}$ and a limitation of the freedom of the individual within the modern nation state. This will later be addressed in detailed in subsequent discussions. However it must be said that to avoid these and other similar acts that attract sanctions, a conscious effort is made on the part of individuals to avoid these infringements and other related actions that can lead to direct confrontation with the chief.

What is problematic is that the Akan society is no longer "traditional." To a larger extent, people no longer attach the same amount of importance to traditional beliefs. As has already been indicated, contemporary changes resulting from socio-economic and political demands as well as changes in religio-cultural, mores, norms, beliefs, values and attitudes have called for the separation of the religious and political prestige and powers which Akan traditional authorities

${ }^{31}$ Asotwe ("ear pulling," from aso, ear and twe, pull) is the generic or umbrella word used for all forms of punishments. It is not quite clear how this word originated. However, my observation of how this punishment is meted out gives me a fair idea of its probable origin. Even to-day, most parents would pull and twist the ears of kids considered as stubborn or naughty. This punishment perhaps emanated from the belief that all instructions and advice pass through the ears into the head (brain). Refusal to do the right thing means one has a "hard ear" (asozden). This "pulling and twisting" of the ear sanction usually goes together with the words w'aso ye den paa (you have a very hard ear), that is, you are a very "bad" child. However, it is still not clear if asotwe is the corrupt form of asotwa ("ear cutting", aso, ear, and twa, cut), an olden form of criminal sanction. Though the later is not heard off or applied today, it was a very popular form of punishment in pre-colonial Akanland. Traditionally, especially in those days, "cutting off the ear" or a piece of the ear was usually used to as a sanction against certain serious crimes. Under this form of punishment, the right ear (or a piece of it depending on one's "sins") was cut. The basis of cutting the right ear, as Rattray has explained, was to prevent the offender from hiding his deformed ear from the public especially using the traditional cloth to cover it. The Akan traditional cloths are usually worn bunched up on the left side of the shoulder. See Rattray, Ashanti Law and Constitution, 376. With these two probable explanations, this paper uses the word in the context of the first explanation.

32 For example, the UN "Convention against Torture and Other Cruel, Inhuman or Degrading Treatment or Punishment," defines torture as "any act by which severe pain or suffering, whether physical or mental, is intentionally inflicted on a person for such purposes as obtaining from him or a third person information or a confession, punishing him for an act he or a third person has committed or is suspected of having committed, or intimidating or coercing him or a third person, or for any reason based on discrimination of any kind..." 
hitherto enjoyed. ${ }^{33}$ The awareness of citizen's constitutional rights, for example, has brought about a host of legal challenges against the Akan traditional leaders, something which was rarely heard in the past. ${ }^{34}$ Contemporary human rights laws have created and promoted, as Sally Engel Merry tells us:

ideas of individual autonomy, equality, choice, and secularism even when these ideas differ from prevailing cultural norms and practices. Human rights ideas displace alternative visions of social justice that are less individualistic and more focused on communities and responsibilities, possibly contributing to the cultural homogenization of local communities. ${ }^{35}$

The changes in people's religious awareness and the dynamism of the society have presented the traditional society with new ethical and moral challenges. Although the chief still wields considerable power in his territory, the traditional and customary institutions of governance which are based on the customs and religious beliefs of the society have been losing much of their powers to the modern nation-state. Traditional and customary values, as Mbiti has noted, are "constantly being smashed, undermined and in some respects destroyed. Emphasis is shifting from the 'we' of traditional corporate life to the 'I' of modern individualism." ${ }^{, 36}$ Against the background of these contemporary changes this research sought to address the challenges that the sacred nature of the chief poses to the full enjoyment of citizens' human rights in the society.

\footnotetext{
${ }^{33}$ Meyer Fortes, Kinship and the Social Order: The Legacy of Lewis Henry Morgan (Chicago: Aldine Publishing Company, 1963), 151.

${ }^{34}$ Fortes, Kinship and the Social Order, 151.

${ }^{35}$ Sally Engle Merry, Human Rights and Gender Violence: Translating International Law into Local Justice (Chicago and London: The University of Chicago Press, 2006), 4.

${ }^{36}$ John S. Mbiti, African Religions and Philosophy, 2nd ed. (Oxford: Heinemann, 1969), 219.
} 


\subsection{Clarification of Terms}

\subsubsection{Chief, King and Queenmother}

In Ghana, the Chieftaincy Act, 2008 Act 759 defines a chief as "a person who, hailing from the appropriate family and lineage, has been validly nominated, elected or selected and enstooled, enskinned or installed as a chief or queenmother in accordance with the relevant customary law and usage." This definition is also reinforced by Article 277 of the 1992 Constitution. Throughout this work, especially in reference to the Akan, a chief, king or queenmother refers to the religio-political leader of an ethno-tribal group of people. Although there has been intense scholarly disaffection about the use of the term "king" in reference to the chief, at the popular level, the people's understanding of the term does not significantly differ. ${ }^{37}$

\subsubsection{Tradition}

Tradition, in this context, refers to the collective religious and legal teachings and practices of a people. It involves the aggregation of the people's customary beliefs and practices that have endured for a very long time in the history of a people. Tradition, throughout this research, will be used interchangeably with religion and beliefs since indigenous African concept of religion goes deeper than the western notion to encompass the people's social, political economic and other institutions of life.

\subsubsection{Traditional Area}

In this study, "traditional area" refers to a geopolitical area under a paramount chief and his officers (the council of elders). In Ghana, a "traditional area" is mostly (though there are few several exceptions) covered by people of the same ethno-tribal, cultural, and socio-linguistic

\footnotetext{
${ }^{37}$ A Kodjo Paaku Kludje, Chieftaincy in Ghana (Lanham: Austin \& Winfiled, Publishers, 2000); E. G. Parrinder, "Divine Kingship in West Africa," Numen 3, no. Fasc. 2 (111AD): Apr., 1956.
} 
background. The territorial integrity and autonomy of a traditional area is given recognition in the country's Constitution and other legislative and statutory instruments.

\subsubsection{Traditional Council}

At the local level, the traditional council is the highest decision making body in a traditional area. ${ }^{38}$ Article 12 (1) of the Chieftaincy Act 2008, Act 759 recommends that "there shall be a Traditional Council in each traditional area." In Ghana, at the traditional council, the paramount chief of the traditional area, except in the case of the Kumasi traditional area, normally is the president of the council. ${ }^{39}$

\subsubsection{Human Rights}

Finding a coherent and non contestable definition of human rights, has, over the years, been a subject of intense scholarly debate especially by international human rights law experts. ${ }^{40}$ Although the concept of human rights goes beyond antiquity, its modern foundation is arguably established in the coming into force of the Universal Declaration of Human Rights. The declaration laid not only "the cornerstone for the consent of human rights but also established the manner in which the whole structure of human rights law is being built." ${ }^{, 41}$

\footnotetext{
${ }^{38}$ Per the article 271 of 1992 Constitution, as well as the Chieftaincy Act 2008, Act 759 and other legislative instruments, the National House of Chiefs, consisting of five paramount chiefs from each region in the country, is the highest decision making body of chiefs. This is followed by the Regional House of Chiefs which is established in accordance with article 274 of the 1992 Constitution.

${ }^{39}$ Article 13 (1) of the Chieftaincy Act 2008, Act 759, for example, states that the "The Paramount Chief of the area or in the case of the Kumasi traditional area, the Asantehene, shall be the President of the Traditional Council." Exception is, however, made in cases where there may be more than one paramount chief in the traditional area. In clause 2 of the just quoted article it is stated that: "In any other case, the Presidency shall be held by the paramount chiefs in the traditional area on a two yearly rotational basis in alphabetical order of stool or skin name.

${ }^{40}$ Robert Traer, Faith in Human Rights: Support in Religious Traditions for a Global Struggle (Washington, D.C: Georgetown University Press, 1991), 2-3.

${ }^{41}$ Traer, Faith in Human Rights, 2.
} 
In his The Idea of Human Rights: Four Inquiries, Michael Perry defined human rights to mean that "there is something about each and every human being, simply as a human being, such that certain choices should be made and certain other choices rejected; in particular, certain things ought not to be done to any human being and certain other things ought to be done for every human being. ${ }^{, 2}$ The study employs Robert Traer's understandings of human rights as the welfare of the individual human beings which has received universal interest. ${ }^{43}$ Thus, although various forms of traditional human rights exist, this study mostly anticipates, and makes reference to the Universal Declaration of Human Rights.

\subsubsection{Religious Human Rights}

To date, no lasting consensus has been reached on the subject of the religious foundation of human rights. For several decades now, this issue has been a subject of strong and intense scholarly debate. The debate between Jack Donnelly and Michael Perry is a well known one. Religious human rights in its simple terms, is defined as the human rights that are associated with religion and beliefs. For purposes of this research, religious human rights, religious freedom and religious liberties will be used interchangeably. It will be used to refer the one and same concept of the freedom that an individual or a community enjoys to (or not to) manifest any religious belief in practice, teaching, worship, and observance and customs of their choice and to (or not) promote such religion without any individual or institutional restrictions, interference, limitation or any other consequences. The said freedom is enjoyed in as much as such religious beliefs do not violate the laws of that particular society. Such violations include the encouragement of fraudulent engagements, evasion of tax, killings, terrorist operations,

\footnotetext{
${ }^{42}$ Perry, The Idea of Human Rights, 13.

${ }^{43}$ Traer, Faith in Human Rights, 2.
} 
subversion of the governments or the laws of the land, the use of "unethical persuasion tactics." Religious human rights also include "cultural rights involving the right to cultural identity and continuity and the right to participate in the cultural life of society and to enjoy the benefits of that activity." 44

\subsubsection{Religious Pluralism}

In the present work, religious pluralism would be used to refer to religious inclusivism. By this is meant the acknowledgement of or the existence of more than one or various types of religious traditions and the peaceful interplay between such traditions.

\subsection{Design and Instrumentation}

Data for this work were derived mainly from secondary sources. The secondary sources used included books, journals, magazines and newspapers as well as legal and statutory documents that touch on chieftaincy institutions especially among the Akan and religious rights and liberties in Ghana. This was accomplished through library research.

\subsection{The Setting: Locating the Akan}

The context of this analysis was the Akan traditional areas of south-western Ghana. However, the research did not cover all of these areas because of the broad nature of the Akan chieftaincy institution and the time frame within which research is carried. Thus even though the context was the Akan area, some of my cases and examples were taken from other areas.

The Akan are found mainly in Ghana and parts of the present day Cote de Ivoire. The exact origin and the meaning of the term "Akan" are quite uncertain and are mixed with a host of

\footnotetext{
${ }^{44}$ Asbjorn Eide, "Dynamics of Human Rights and the Role of the Educator," in Frontiers of Human Rights Education, ed. Asbjorn Eide and Marek Thee (New York: Columbia University Press, 1983), 105.
} 
interesting legends. It is believed that the term might have etymologically originated from the word kan, which could appropriately be interpreted as first, foremost, beginnings, to lead, genuine, pure, light, count or reckon, to read, to cry or wail (especially during funeral dirges). ${ }^{45}$ When the word is interpreted as first or foremost, it is used to designate the Akan as pioneers, the first group of people to have settled in what is now known as the modern Ghana. Other traditional myths extend it to be the first group of people ever to have walked on the face of the earth. For example, the history of the Bono (also an Akan group) people is filled with mythical past. They are believed to be the first to have been created hence their name, Bono (from $b o$, create and $n o$, him, her, it). ${ }^{46}$

When the word is interpreted as "to read," the Akan see themselves as the first to have been given the gift of oratory and public speech. ${ }^{47}$ Interpreted as light, the Akan are conceived as "the first to have seen light and would therefore, as leaders, have a message to impact to others. ${ }^{48}$ The Akan traditionally believe themselves to be the first in everything and also view themselves as culturally superior; an assertion which has, at the popular level, attracted a host of traditional enemies even to date.

The historical origin of the Akan, as has been observed, is mixed with a host of legends. Common descent, however, is an essential key to one's Akaness. For early scholars like J.B. Danquah, the origin of the word, Akan, can be traced back to the ancient Akkad/Akana city of

\footnotetext{
${ }^{45}$ Anthony Ephraim-Donkor, African Spirituality: On Becoming Ancestor (Trenton \& Asmara:: African World Press, 1997), 3.

${ }^{46}$ Other historians and mythologists also opine that the name might have originated from bono, (the Bono word for hole) as the people are said to have originated from a mythical hole near Yefiri in the Nkoranza North District of modern Ghana. See also Osman B. Bari, A Comparative History of Muslims and Religion in Ghana, vol. 1 (Accra: Dezine Focus, 2009), 213.

${ }^{47}$ Ephraim-Donkor, African Spirituality, 3-4.

${ }^{48}$ Ephraim-Donkor, African Spirituality, 4.
} 
ancient Babylon. This idea has further been developed by subsequent writers. For example, in Revelation: The Movement of the Akan People from Kanaan to Ghana, the author attempted to trace the movement of the Akan people from as far as ancient Mesopotamia. He blamed both western and local scholars for concealing the real identity of the Akan by not revealing what he considered to be the "facts" about the origin of the Akan people. ${ }^{49}$ It is not clear what the motivation for such a project was but the author described part of his purpose thusly:

After the western religious and scientific researchers have failed to perform their duties right, trying to blind other people, finding ways to deny the AkAn and GuAn people from their origin as founders of Chaldear (Babylon), Aramaic Kingdoms, Edom, Kanaan, Israel, Carthage, Carthage Nova, RaSena (Etrusker), Kapua, KreTa, Kibi, BilMa, GaNa and SonGhaye; we the AkAn and GuAn folk of today have taken up our tools and have gone beyond our ancient GaNa and SonGhaye Empires until we could break down that untouchable Bible into pieces."

For AkanBa, the migration took several centuries and moved in such different directions and areas that a lot of important facts and memories have been lost. It takes revelation to unravel it. "We have moved further towards Edom; we went over Israel, and made a stop-over at Syria, we cruised on, until we could penetrate through two rivers in Babylon, the land of Koa, the land of $\mathrm{KaSi}$, the land of $\mathrm{KeSe}, \ldots$ to bring out our gracious blessed AkAn and GuAn religious history." ${ }^{, 51}$ Other versions of the origin of the Akan exist in the literatures. Historically, the Akan are believed to have originated from a common mythic female progenitor. According to Meyerowitz and J.B. Danquah, the Akan belong to the falcon clan of people who once ruled the kingdom of Diadom (Djadum) in the western region of Tibesti mountain; between the Sahara and the

\footnotetext{
${ }^{49}$ AkanBa, Revelation: The Movement from Kanaan to Ghana (Central Milton Keynes: AuthorHouse, 2010).

${ }^{50}$ AkanBa, Revelation, 8.

${ }^{51}$ AkanBa, Revelation, 8.
} 
Nubia. ${ }^{52}$ It is said that following the unrest that came with the Arab invasion of North Africa in the seventh and eighth centuries, the royal people of the Dia dynasty, ${ }^{53}$ accompanied by a large number of followers, decided to emigrate southwards. They first settled along the Niger bend between Djenne and Timbuktu.

At the region south of the Volta River, the Bono people established their kingdom. According to Meyerowitz, the "Bono Kingdom became the wealthiest and most civilised among all the Akan states, including Asante. ${ }^{, 54}$ Some Akan states, during this period came under the control of the Bonohene (king of the Bono). According to the British historian and Africanist writer, Basil Davidson, the king of Bono-Manso became "a king of kings. He became even if in a small way, an emperor. ${ }^{, 5}$ Meyerowitz described the link between the kingship system of the time and the ancient Egyptians as:

The more I became acquainted with the Akan beliefs and customs, the more I realised that they were not isolated phenomena. It became clear to me that they were ultimately based upon those of Ancient Egypt. Time and place and historical change had so much modified these religious forms as to produce effects which made them not indeed repetitions of the Egyptian example but obvious derivations from it. ${ }^{56}$

It must however be said that the notion of divine kinship in the context of Africa, along with those of the views of Frazer has been challenged by scholars like Luc de Heusch. According to Heusch, the concept of divine kingship is a mistaken notion. Particularly in black Africa, there is no credible evidence to suggest that the king is assimilated with divinity as was the case in

\footnotetext{
${ }^{52}$ Eva L. R. Meyerowitz, The Divine Kingship in Ghana and Ancient Egypt (London: Faber and Faber Limited, 1960), 23.

${ }^{53}$ It is not clear the exact location and founder of the dynasty. However, some scholars believe that the Dia dynasty might have been founded by the hero, Dia, who is believed to have migrated from Yemen. See Dierk Lange, AfricaCentred and Canaanite-Israelite Perspectives (Dettelbach: Verlag J.H. Röll, 2004), 463-66.

${ }^{54}$ Meyerowitz, The Divine Kingship, 16.

${ }_{55}^{55}$ Basil Davidson, A History of West Africa 1000-1800, New Ed. (London: Longman Group Ltd, 1977), 90.

${ }^{56}$ Meyerowitz, The Divine Kingship, 16.
} 
ancient Egyptian civilization. ${ }^{57}$ What really was, (and still is) the case, according to Luc de Heusch, is that "in black Africa, it would be truer to say that through a special ritual of investiture, a particular person, whose political power varies enormously, is endowed with a unique property, best understood by considering that the holder is transformed into a 'freshbody." ${ }^{58}$ Through the ritual of coronation, the person of the chief is symbolically transformed into a sacralized body. He assumed the position of the dead ancestors whose seat he is placed on. ${ }^{59}$

It is believed that at the beginning of the eleventh century, the falcon clan people emigrated further southward to avoid embracing Islam when Islamized Tuaregs from the Sahara conquered the kingdom. They finally founded the Bono, and subsequently, other kingdoms of pre-colonial Ghana.

Statistically, the Akan constitute about $49.1 \%$ of the population of Ghana ${ }^{60}$ The Akan sub-group of people in Ghana include: Adansi, Agona, Ahafo, Ahanta, Akwamu, Akwapim, Akyem, Asante, Assin, Bono, Denkyira, Fante, Kwahu, Nzema, Sefwi, Twi, and Wassa. Linguistically, the Akan belong to the Kwa group of languages ${ }^{61}$ Notwithstanding the dialectical difference between the various generic Akan languages, Twi and Fante, there is a seeming

\footnotetext{
${ }^{57}$ Luc de Heusch, "Forms of Sacralized Power in Africa," in The Character of Kingship, ed. Declan Quigley (Oxford and New York: Berg Publishers, 2005), 25.

${ }^{58}$ Heusch, "Forms of Sacralized Power in Africa," 25.

${ }^{59}$ See Heusch, "Forms of Sacralized Power in Africa," 28. See also Audrey I. Richards, "Keeping the King Divine," Proceedings of the Royal Anthropological Institute 6, no. 2 (1968): 23-35.

${ }^{60}$ This is based on the 2000 Population and Housing Census results. Current results for the 2010 census are still not out.

${ }^{61}$ See David Kimble, A Political History of Ghana: The Rise of Gold Coast Nationalism 1850-1928 (Oxford: The Clarendon Press, 1963), 509; Kofi Agyekum, "Ntam 'Reminiscential Oath' Taboo in Akan," Languages in Society 33, no. 3 (June 2004): 317-342. http://www.jstor.org/stable/4169351. [Accessed: February 11, 2011].
} 
intelligibility between these dialects. There is virtual consensus that the Twi language is spoken and understood by about $80 \%$ of the Ghanaian populace.

\subsection{Structure of the Study}

The various chapters in this research were all designed to center around the question of how the sacred nature and office of the Akan chief undercut the full enjoyment of the human rights of people living under the jurisdiction of the chief. For easy analysis, this research was divided into eight main chapters. These are:

Chapter I: General Overview of the Study

Chapter one gave a general overview of the research. This included the introduction, background to the study, thesis, a brief conceptual framework, classification of terms, design and instrumentation, the setting and structure of the study.

Chapter II: Exploring the Conceptual Underpinnings

Chapter two laid the theoretical foundation upon which the central and sub-arguments of this thesis depended. Drawing on the arguments presented by scholars such as Merci Eliade, Clifford Geertz, and Antonio Gramsci (and not only these scholars), I attempted to show what the sacred in the Akan chieftaincy institution is and how it conveys meaning within Akan societies. That notwithstanding, the ideological rhetoric associated with this institution can (and has mostly been) deconstructed as hegemonic and abusive which must be resisted.

Chapter III: The Religious Foundation of the Akan Chieftaincy Institution

Chapter three gave a review of the religious field upon which the powers and authority of the chief operate in the Akan society. It also gave an assessment of the religious views of the Akan people and the sources of moral laws in the community upon which the authority of the chief resides. 


\section{Chapter IV: The Metaphors of the Akan Sacred Chief}

What is it about the Akan chief that make his subjects see him with a different eye in the society? Why must the chief be seen as over and above his people? Chapter four attempted a detailed exploration of the sacrality associated with the person and office of the Akan chief. It explored how religion has been used as the basis for the legitimization of the position of the Akan chief. Attempt was made to examine the sacred nature of the Akan chief as well as the symbols and beliefs associated with his office that make the person and the office of the chief sacred.

Chapter V: Chieftaincy and the Impact of Colonialism and Christianity

In the fifth chapter, I made an effort to analyze the position of the chief in the face of the changing society. The chapter took a brief historical survey of how colonialism and the introduction of Christianity in particular became essential forces which served as a challenge to the chieftaincy institution.

Chapter VI: Chieftaincy, Modernization and Globalization

Modernization and globalization, which followed the contact with European imperialists, opened the indigenous societies to a lot of changes which impacted dramatically on the indigenous societies. However, the disadvantaged position of the indigenous societies did not promote level play ground to compete with these external forces and allow the ethno-political leaders from getting the full benefit of these changes. In chapter six, I continued the exploration with the impact of the "twin evils" of modernization and globalization and how these forces have challenged and affected the position and office of the Akan chief and the response the chief has given to these forces. 
Chapter VII: Chieftaincy and Human Rights: Issues of Concern

The clash between the forces of modernization and the traditionalism always presents certain challenges. In such a clash, what are the human rights implications for the individual who adheres (or otherwise, does not adhere) to the authority of the chief? How does the chief respond to such a clash? What innovative options lie ahead for the parties involved in such a clash? These were the concerns of the seventh chapter. The chapter discussed how the chief has expressed his frustration and his shock over the impact these external forces. It also argued that the forces of change bedeviling the institution are not only external but also certain internal activities such as the excessive exercise of chiefly powers have called for desacrailization of the authority of the chief.

Chapter VIII: Summary, Significance and Conclusion

The eighth chapter brought the reader to a sense of completeness and closure to the various discussion made in this study. It gave a brief recap of the whole discussion and, at the same time, gave a summary of the findings, significance of the research and policymaking recommendations. 


\section{CHAPTER II: EXPLORING THE CONCEPTUAL UNDERPINNINGS}

\section{$2.1 \quad$ Introduction}

This chapter conceptualizes how religio-cultural beliefs and practices associated with the sacred nature and office of the Akan chief help people to understand and to respond to the world around them. Drawing on relevant theoretical frames of some selected scholars, the chapter explores the foundational basis of the prominence of the sacred nature of the Akan chieftaincy institution and how this becomes meaningful in the daily socio-political constellation of people within Akan traditional areas.

\subsection{Chieftaincy and the Concept of the Sacred}

In his Patterns in Comparative Religion, Mircea Eliade explored the significant role that religious symbols play in the life of the religious adherents. He observed that a religious phenomenon:

will only be recognized as such if it is grasped at its own level, that is to say, if it is studied as something religious. To try to grasp the essence of such a phenomenon by means of physiology, psychology, sociology, economics, linguistics, art or any other study is false, it misses the one unique and irreducible element in it- the element of the sacred. ${ }^{62}$

Similarly, in The Sacred and the Profane, Eliade forcefully argued that the first attempt that historians of religion who try to understand religion makes is a very significant one. In doing so the historian, he advised, must go beyond the borders of modern civilization. ${ }^{63}$ Modern civilization, he said, only accounts for a small and current portion of the whole story of the people who ever lived. The historian of religion must therefore enter into the world of what he

\footnotetext{
${ }^{62}$ Mircea Eliade, Patterns in Comparative Religion, trans. Rosemary Sheed (New York: Meridian Books, 1949), xiii..

${ }^{63}$ Daniel L. Pals, Eight Theories of Religion, Second ed. (New York and Oxford: Oxford University Press, 2006), 196.
} 
referred to as "archaic man." The lifestyle of the archaic man, he said, is a life within tribal societies and of practiced folk cultures. This lifestyle, Eliade explained, is a life based on two distinctly diverse modes or realms; the realm of the sacred and that of the profane ${ }^{64}$ Daniel Pals succinctly summaries Eliade's argument thus:

the profane is the realm of the everyday business- of things ordinary, random, and largely unimportant. The sacred is just the opposite. It is the sphere of the supernatural, of things extraordinary, memorable, and momentous. While the profane is vanishing and fragile, full of shadows, the sacred is eternal, full of substance and reality. The profane is the arena of human affairs, which are changeable and often chaotic; the sacred is the sphere of order and perfection, the home of ancestors, heroes, and gods. ${ }^{65}$

It is interesting to note that although Eliade used this concept to refer to the archaic people, it is not limited and applied to them alone. The notion can be extended to the Akan of Ghana. For Akan people, while the position of the chief and other symbols and rituals associated with the office may seem so ordinary to the outsider, such beliefs occupy an essential space in their religio-cultural ethos. The stool, the seat of chiefly governance, for example, might be an ordinary chair in the eyes of the ordinary man rather than a chiefly or religious symbol. However, when a profane object is transformed into a sacred object, it does not lose its profane essence. As Eliade himself elucidates, in matters of sacrality, a sacred stone, for example, may still retain its stoneness; and it may, in fact, remain essentially so from the profane point of view. Such a stone is not distinguishable from all other stones. ${ }^{66}$ The situation is, however, not the same for those to whom a stone manifests itself as sacred. This is because, in this case, "its immediate reality is transmuted into a supernatural reality. In other words, for those who have a

\footnotetext{
${ }^{64}$ See Mircea Eliade, The Sacred and The Profane: The Nature of Religion, trans. William R. Trask (Orlando: Harcourt, Inc., 1957), 12-13; Pals, Eight Theories of Religion, 199.

${ }^{65}$ Pals, Eight Theories of Religion, 199.

${ }^{66}$ Eliade, The Sacred and The Profane, 12.
} 
religious experience all nature is capable of revealing itself as cosmic sacrality. The cosmos in its entirety can become a hierography."67

The Akan stool, the seat of power and authority, carved from an ordinary wood does not remain a mere wooden stool. Once it is attached to a religious signification, its reality is transformed or to borrow Eliade's word, transmuted into a mystical reality. Indeed, the "manifestation of the sacred in an object does not constitute idolatry. It is not the sacred object per se but rather the object points to a reality beyond itself." 68 Similarly, among the Akan, the chief is not only a sacred person of his own. His sacred nature, in the minds of the Akan, goes beyond simply being the political leader of the community. Such notion is similar to and reflective of what Eliade observed when he said: "A thing becomes sacred insofar as it embodies (that is, reveals) something other than itself." ${ }^{69}$ According to Eliade, the king, because of his sacred office, is "an absolute powerhouse of forces simply because he $i$ s a king, and one must take certain precautions before approaching him; he must not be directly looked at or touched; nor must he be directly spoken to, and so on. In some areas the ruler must not touch the ground, for he has enough power in him to destroy it completely; he has to be carried, or to walk on carpets all the time." 70

The concept of the sacred is not limited to the person of the chief alone but also the symbols and metaphors associated with his office. According to Eliade, religious people do not experience the same standardized form of space. Some spaces are "qualitatively different from

\footnotetext{
${ }^{67}$ Eliade, The Sacred and the Profane, 12.

${ }^{68}$ John D. Dadosky, The Structure of Religious Knowing: Encountering the Sacred in Eliade and Lonergan, (Albany: State University of New York Press, 2004), 67.

${ }^{69}$ Eliade, Patterns in Comparative Religion, 13.

${ }^{70}$ Eliade, The Sacred and The Profane, 16-17.
} 
others." ${ }^{, 71}$ For Eliade, "When an object becomes a hierophany, it is separated from, cut off from the rest of the "profane" world and becomes a locus of valorization.",72 Eliade points out that the sacred manifests itself not only in natural objects but also in artificial objects. The manifestation of the sacred, hierophany, also takes place in sacred spaces, "a place where communication with sacred power is made possible." ${ }^{, 73}$ Such a sacred place, according to Eliade is the axis mundi, the center of the world. He offered some characteristics features of the sacred space as:

(a) a sacred place constitutes a break in the homogeneity of space; (b) this break is symbolized by an opening by which passage from one cosmic region to another is made possible (from heaven to earth and vice versa; from earth to the underworld); (c) communication with heaven is expressed by one or another of certain images, all of which refer to the axis mundi. ${ }^{74}$

The entrance of the sacred spaces serves as a boundary between the profane on the outside and the sacred objects and nature within those spaces. The sacred space serves as a hedge around the holy entities and communications that goes on between the mundane creatures and the sacred forces of the society. Eliade's concept of the sacred is still useful in our analysis of the significance of the stool and the stool-house of the Akan. Later in the chapter four, using this same concepts, I will demonstrated how the stool-house, royal store house of keeping chiefly stools of the ancestors, for example, also assumes a transcendent nature. The stool-house no longer becomes a sheer royal furniture house but rather a symbol of the sacred abode of the ancestors.

\footnotetext{
${ }^{71}$ Elaide, The Sacred and the Profane, 20.

72 John D. Dadosky, The Structure of Religious Knowing: Encountering the Sacred in Eliade and Lonergan (Albany: State Univ of New York Press, 2004), 68.

${ }^{73}$ James C. Livingston, Anatomy of the Sacred: An Introduction to Religion, 6th ed. (Upper Saddle River: Prentice Hall, 2009), 43.

${ }^{74}$ Elaide, The Sacred and the Profane, 37.
} 
In his The Myth of Eternal Return, Eliade, again, observed the close relationship between symbolism and psychoanalysis. According to him:

[T] he symbol reveals certain aspects of reality-the deepest aspects- which defy any other means of knowledge. Images, symbols, and myths are not irresponsible creations of the psyche; they respond to a need and fulfill a function, that of bringing to light the most hidden modalities of being. Consequently, the study of them enables us to reach a better understanding of man- of man "as he is," before he has come to terms with the conditions of History. ${ }^{75}$

Indeed, traditional Akan attach so much importance to the symbol of the stool. The stool is a traditional symbol of honor and recognition. In the olden days, people (especially sub-chiefs) whose devotion and activities are considered as meritorious were given stools as a symbol of their recognition. ${ }^{76}$

In Patterns in Comparative Religion, Eliade observed that the wall or the boundaries around sacred places "does not only imply and indeed signify the continued presence of a kratophany or hierophany within its bounds; it also serves the purpose of preserving profane man from the danger to which he would expose himself by entering it without due care."77 Thus as a sacred institution within a "profane" space - secular society - care must be taken in dealing with the office of the chief and its associated symbols. The institution evokes ambivalence.

\subsection{Chieftaincy as a Cultural Symbol}

The above analysis, however, presents a lot of challenges in contemporary society. As already been indicated, the chief might be sacred alright but if this sacrality is not meaningful in the society, it will remain unacknowledged and only him, the chief, and people close to him will

\footnotetext{
${ }^{75}$ Mircea Eliade, The Myth of Eternal Return, trans. W.R. Trask (Princeton, NJ: Princeton University Press, 1991), 18.

${ }^{76}$ Sarpong, The Sacred Stool of the Akan, 19.

${ }^{77}$ Eliade, Patterns in Comparative Religion, 370.
} 
make sense out of it. Thus, the sacred nature of the chief must be meaningful in the ethos of the people. It must present some compelling and persuasive meanings in the minds and lives of the people in the society. It is for this reason that the work of the American anthropologist, Clifford Geertz, on The Interpretation of Cultures becomes significant to this research. According to Geertz, the motivation of human actions must be analyzed on the basis of the meaning attached to it. For him, culture is part of the symbols human create and these symbols are anything that human beings attach meaning to. He used the term culture to mean "a pattern of meanings," or ideas carried in symbols, by which people pass along their knowledge of life and express their attitudes toward it. ${ }^{78}$ Everything, he said, has meaning to a particular people. By symbols one can talk about any object, action, event, relationship, or anything else that conveys some meaning to someone. These symbols all have meanings: they convey some message to the believers about the nature of their world. Symbols teach believers to see or understand their world in a particular way. Symbols, thus, shape the believers' experience. In other words, symbols transmit or communicate something about the worldview of adherents - a picture of how things are in the world. According to Geertz, "sacred symbols function to synthesize a people's ethos- the lone, character and quality of their life, its moral and aesthetic style and mood - and their world viewthe picture they have of the way things in sheer actuality are, their most comprehensive ideas of order.",79

Using Geertz's analysis, this study argues that religious symbols such as the symbol of the stool among the Akan motivate - signal or help people - to react to certain socio-political and religious situations in the society. Geertz's analysis will be used to argue that contrary to the

\footnotetext{
${ }^{78}$ Pals, Eight Theories of Religion, 270.

${ }^{79}$ Clifford Geertz, The Interpretation of Cultures (New York: Basic Books, 1973), 89.
} 
attacks against religious symbols such as the stool - the symbol of tribal identity of the Akan of Ghana - the stool still has a lot of relevance in the contemporary socio-political world. For Geertz, religion itself is a system of symbols, creeds, rituals etc. Thus, religion and its symbols must not be studied as one would study, say economics or psychology, as an academic subject. An attempt must be made to tease out the meaning of what are involved in particular religious traditions. Supporting my argument with Geertz's ideas of religion as a cultural symbol system, the beliefs and values behind the symbols of the Akan people will be elaborated.

With Geertz's analysis, one finds that religious symbols work to persuade adherents that there is a good relation between the nature of reality and the way human beings live. These symbols give the adherents the hope that both reality and their lives make sense- that there is some meaningful order rather than mere chaos in their lives. Among the Akan, the concept of the tripartite nature of power of governance in the society gives one a sense of socio-political and religious meaning in life. The belief is that the society is ruled by the spiritual forces (the ancestors who are also the owners of the land), the chief (the tribal leader, the earthly representative of the ancestors) and the people (the tribal members of the society). Though each of these agents of authority is important, the ancestors are said to be the most significant power among the three arms of authority. They are the "life giving" principle of the society. The success and blessings of the land depend on their approval. No one has dominion over the ancestors. Despising the authority of the chief, the representative of the ancestors, therefore, destroys the harmony that exists between the people and the spiritual forces whose wrath can bring anomie in the society. To the traditional Akan mind, this belief cannot be said to be irrational as Sigmund Freud, for instance might assume or as a tool of social oppression as Karl Marx and his followers would argue. For the traditional Akan, fear of chaos in the society 
associated with flouting the rules of the ancestors, trumps fears of both illusion and exploitation inherent in the belief in the power of the stool.

Equally important in Geertz's analysis about culture and its symbols is that "religion clothes its conceptions of order with an aura of factuality." ${ }^{\circledR 0}$ This is especially the case in the context of the Akan concept of belongingness. Among the Asante, for example, to refer to someone as ote kokooso nana (the grandchild of him who sits on the golden stool), is a sense of greater pride. The golden stool is the symbol of solidarity among the Ashanti. Its totem, the porcupine, has as its slogan, kum-apem-a-apem-bebe (if you kill thousand, thousand more will fight back). Like the proverbial porcupine, the more the quills or the sharp spines which the porcupine uses to defend or camouflage its predators are removed, the more they are mystically replaced. For the Asante, the belief is that it is only futile and a waste of effort to dare such mystical animal (totem). Thus, the golden stool is not only the seat of the Asantehene (king of the Asante) but also the rallying point of the people. This has meaning for its people.

Geertz observed that religious adherents have always relied on ritual as an important avenue of coping with the struggles of daily life. They are convinced that their worldview and way of life are indeed "true, good, and ultimately fulfilling." The adherents use religious symbols and rituals which together reinforce the commitment of their worldview and ethos in life which is the way that our society teaches its people to live and to experience life. Thus, from Geertz's analysis, it can be said that belief in such religious symbols is not unreasonable. Such belief still evokes new types of awareness and different modes of belongingness. The basic argument against the sacrality of the stool and hence the extension of such sacrality to the chief is that the chief's socio-political functions have been taken over by the political leaders of the

${ }^{80}$ Geertz, The Interpretation of Cultures, 109. 
new nation-state. The religious powers associated with the stool have been taken over by the emergence of other religious traditions in the society. Of what use then is the religio-political office of the chief in the context of this religiously pluralistic and democratic society?

That notwithstanding, events in the society which will be discussed throughout this study reveals that the institution is still meaningful and relevant. The stool, the office of the chief, as a religious symbol, represents the ethnic communities. In Ghana, as in other indigenous African societies, the tendency to assert ones ethnic identity in the face of nation political crisis has been a frequent phenomenon. In times of national confusion, people's sense of solidarity, what Albert Awedoba refers to as "wee-feeling," - apathetic sense of belongingness- takes a different dimension. Ethno-tribal solidarity and oneness rather becomes stronger than before. Although most people are not prepared to partake in the traditional rituals associated with the stool, many feel proud of their ethnic background and its proverbial rich culture. Their dilemma arises from the demands of their new-found religious traditions which prevent them from participating in such traditional rituals associated with the stool. For such people they have often changed their religious affiliation but their ethnic background cannot be altered. What needs to be done about it is the reformation of the customs and traditions associated with the stool that seeks to be problematic.

\subsection{Hegemony and Chieftaincy Institution}

Contemporary events in the society, has however, challenged the perception and meaning people give to the sacredness of the chief. Religious pluralism, for example, has presented alternative forms of reality in the society such that the symbols and meanings associated with the chief have been challenged. The chieftaincy institution, conscious of this event, attempts to rally all resources available to translate to people that the office of the chief is still viable. In 
collaboration with the new nation state - conscious of the mutual interdependence of each other - attempts have been made, over the years, to make the institution remain viable, through the creation of National House of Chiefs and other Acts and legal instruments aimed at enhancing the institution. Traditional festivals have also been important avenues to project not only the cultures of the people but also enhance the image of the chieftaincy institution. Using the state powers and the little power available to the chief, they attempt to desperately wield their control and influence. In most cases, innocent and powerless individuals are affected. This study explores the human rights implications of what is seen by many as the hegemonic domination of the chief in the modern society.

In order to understand how hegemonic ideas operate within the context of the chieftaincy institution, it is important to briefly understand Gramsci's concept of hegemony and how it is used to dominate the ruled of society. The Italian political theorist and philosopher, Antonio Gramsci, used the concept of hegemony to refer to the type of cultural leadership exercised by the dominating group of society. Gramsci, though a Marxist theoretician, rejected Marx's laws of history and rather developed his concept of the cause of class struggle in society or what he referred to as the superstructures of capitalism. Gramsci's interest in domination and reproduction in society served as the fertile ground for the production of his idea of hegemony which he distinguished from hegemony and coercion. He rather focused on the role of "cultural and intellectual factors" in the reproduction of domination and class control in the society. ${ }^{81}$

In accounting for domination and inequalities in the society, Gramsci opined that attention must be paid to the daily routine structures and "common sense" values propagated by

${ }^{81}$ Joseph V. Femia, Gramsci's Political Thought: Hegemony, Consciousness, and the Revolutionary Process (Oxford: Clarendon Press, 1981), 3. 
"intellectuals". His concept of "intellectual" did not involve the elitist's sense of the word. ${ }^{82}$ According to him, intellectuals are a group of people whose activities elicit consent in the society. For Gramsci, hegemony is distinct from coercion, which mostly employs the use of the state apparatus and the security forces to maintain dominant position. Intellectuals, he said, rather create and fashion an ideology that seeks to perpetuate their dominant position in society. They provide the justificatory basis upon which the dominant ideas of the society prevail. This ideology assures the subordinating groups- those without "the philosophy of the philosophers" that their position is natural, proper, expected and fair. As a result, the dominated group of the society come to the appreciation that their situation in life is both ration and inevitable and must be accepted.

The Gramscian theory of hegemony evokes some significant concepts which can be applied to how religious institutions and symbols such as the Akan chieftaincy institution and the stool become detrimental to the enjoyment of people's human rights. Notwithstanding the earlier claims that the chieftaincy institution, symbolized by the stool, is the unifying factor in the traditional society, it must also be added that the strongest adherents of the stool and its influential powers in society are mainly the direct beneficiaries of this stool and as such may be the tools of oppression for others. For, as the Marxists argue, if someone seemingly who has no benefit and is not linked to the stool nevertheless supports the stool, the objection will still be that, it is because of the powerlessness of such as a person. A Marxist would say this would be because of false consciousness - this person has not understood his or her own best interests, but has been taken in by the ideology supporting the stool. Such a person has been made to believe

\footnotetext{
${ }^{82}$ Antonio Gramsci, Selections from the Prison Notebooks of Antonio Gramsci, trans. Quintin Hoare and Geoffrey Nowell Smith (London: Lawrence and Wishart, 1971), 5-23.
} 
in the prevailing and overarching "verbal trick ${ }^{83}$ that religious statements entail and so has mistakenly given consent to his own oppression." ${ }^{\circledR 4}$ Thus, the verbal trick inherent in the power of the stool has been used as a form of social control and domination of the many who have to submit to the power of the stool. It must be said, however, that just as likely, though, and often part of the trick is that powerless people support power institutions in hopes of gaining some advantage from their support.

These concepts are relevant to a Gramscian notion of "spontaneous consent." Gramsci defined "hegemony as a cultural and ideological means whereby the dominant groups in society, including fundamentally but not exclusively the ruling class, maintain their dominance by securing the 'spontaneous consent' of subordinate groups, including the working class." tendency to defend chiefly hegemony in the context of culture, which of course must be upheld, is always high. It is therefore important to distinguish between the two. By culture we are referring to what Christopher Dawson defined as "an organized way of life which is based on a common tradition and conditioned by a common environment." ${ }^{, 86}$ As Williams puts it:

'Hegemony' goes beyond 'culture', as previously defined, in its insistence on relating the 'whole social process' to specific distributions of power and influence. To say that 'men' define and shape their whole lives is true only in abstraction. In any actual society there are specific inequalities in means and therefore in capacity to realize this process. In a class society these are primarily inequalities between classes. Gramsci therefore introduced the necessary recognition of dominance and subordination in what has still, however, to be recognized as a whole process. ${ }^{87}$

\footnotetext{
${ }^{83}$ Emphasis is mine.

${ }^{84}$ Meic Pearse, The Gods of War: Is Religion the Primary Cause of Violent? (Nottingham: IVP Books, 2007), 136.

${ }^{85}$ Dominic Strinati, An Introduction to Theories of Popular Culture, 2nd ed. (London: Routledge, 2004), 147.

${ }^{86}$ Christopher Dawson, Religion and Culture, First ed. (New York: Sheed \& Ward, 1948), 47.

${ }^{87}$ Raymond Williams, Marxism and Literature (New York: Oxford U.P., 1977), 108.
} 
It is then far fair to say that hegemony, over time, becomes the core basis of culture. Williams' observation, therefore provides an insightful basis for understanding how hegemony is developed in the society. With this in mind, the argument can be formulated that the ruling class, in an attempt to dominate and preserve their influence and interests in the society constructs such ideologies meant to dominate the rest of the societal members. With time, these sets of ideologies become hegemonic and, subsequently, the justificatory basis of culture. With this assumption in view, one therefore sees similar patterns in the discourse of the Akan chieftaincy institution.

The seemingly shaken foundation of what used to be the impenetrable or unchallenged basis of the sacrosanct office of the chief, I argue is part of a counter-hegemonic discourse. I argue that sacrality is not only the hegemonic foundation that perpetuates the dominion by the traditional authority, but it is also a conceptual basis for disaffection and rebellion against the status quo which can lead to violence and conflict in the society. The concept of sacrality associated with the chief's office and personality, in most cases, induces both overt and covert submission and allegiance to the power of the chief. The concept of sacrality, in a Gramscian sense, provides an ideological fusion of consent and coercion not only for outsiders but even for members of the same ethnic group. ${ }^{88}$ Gramsci, for instance, opines that cultural hegemony is not imposed on the subordinated group through the use of force and violence but rather through selfwilling acquisition of the values of the dominating group. According to him, social groups achieve their supremacy not by brute physical force and violence, what he referred to as domination or command, but rather through mutual consent from the dominated to willingly submit themselves to the powerful. The powerful who take up political leadership positions in

\footnotetext{
${ }^{88}$ David D. Laitin, Hegemony and Culture: Politics and Religious Change among the Yoruba (Chicago and London: The University of Chicago Press, 1986), 105.
} 
the society "became merely an aspect of the function of domination." 89 With time, the subordinate class acknowledge their helplessness and vulnerability, and come to accept it as natural and part of their existing order. Their situation comes to be seen as "natural" and "inevitable." According to Gramsci, with time, these subordinate groups come to appreciate norms and cultural values of the ruling class as pure, uncontaminated and worth emulating while rejecting their own as obsolete, superseded and out-of-date. The rulers, taking advantage of the helplessness of the ruled, tend to oppress them. According to Gramsci:

Since the division between the rulers and the ruled exists even in within the same group, certain principles have to be fixed upon and strictly observed. For it is in this area that the most serious "errors" take place, and that the most criminal weakness and the hardest to correct are revealed. For the belief is common that obedience must be automatic, once it is a question of the same group; and that not only must it come about without any demonstration of necessity or rationality being needed, but it must be unquestioning. ${ }^{90}$

Historical and contemporary events within the Akan societies of Ghana have proved Gramsci's observation to be quite significant in the context of the chieftaincy system. The domination associated with the institution cannot be adequately stressed.

Hegemony, though subtle and dangerous occurs by "co-opting dissenting voices through subtle dissemination of the dominant group's perspective as universal and natural, to the point where the dominant beliefs and practices become an intractable component of common sense."91 Gramsci's perspective on hegemony helps us to understand that the Akan chieftaincy institution which is based on the sacrality of the stool is not merely a product of hegemony but, also through misuse of the power it confers can become an avenue for violence and abuse of people's religious rights, producing conflict and resistance. Some instances of conflict between the chief

\footnotetext{
${ }^{89}$ Gramsci, Selections from the Prison Notebooks, 59.

${ }^{90}$ Gramsci, Selections from the Prison Notebooks, 145.

91 Douglas Litowitz, "Gramsci, Hegemony and the Law," Brimham Young University Law Review (January 1, 2000): 515-551.
} 
and citizens especially in the early period of the country's modernization process will be dealt with in details later in subsequent chapters.

\subsection{The Sacred, Hegemony and Human Rights}

With the acceptance of modernization and its associated democratic or modern forms of governance and plurality of religion, must the stool still be seen as the symbol of authority in the society? Are there any sanctions for people who knowingly or unknowingly flout the beliefs and practices associated with the chieftaincy institution? In this section, I explore how despite the changing times and plurality of lifestyle in many tribal societies, any attempt to trivialize religious symbols as irrelevant in contemporary society posses some contradictory challenges to individual, the chief, the modern nation-state and international human rights. As a symbol of the ethno-tribal state, the stool is shrouded in codes of behavior and morals that keep members of the society from many forms of anti-social life. The stool, it has already been argued, serving as a symbol of the ancestral abode, also reminds members of the community of the do's and the don'ts of the society.

An important "common sense" associated with the belief in the stool as a religious symbol among the Akan of Ghana is its transformative possibilities ${ }^{92}$ in the societies. Assessing how it has been able to go through the challenges of the time, the "ongoing experiences and in the process confirm, or modify, the body of ideas and institutions prevailing in that society" ${ }^{93}$ will help us understand this better. The stool as the symbol of authority of the chief has already been said to be the legitimization force for social order. Seen as the principal rallying point for

\footnotetext{
${ }^{92}$ This term was borrowed from Abdullahi A. An-Na'im in Abdullahi A. An-Na'im, "The Politics of Religion and the Morality of Globalization," in Religion in Global Civil Society, ed. Peter Juergensemyer (Oxford and New York: Oxford University Press, 2005), 25.

${ }^{93}$ Satish Sabrewal and Supriya Varma, introduction in Satish Sabrewal and Supriya Varma (eds;) Traditions in Motion: Religion and Society in History (New York, Oxford: Oxford University Press, 2005), p. 1-2.
} 
mobilizing the tribal and ethnic people who pay allegiance to it, the stool also serves as the direct legitimation force for ethno-tribal solidarity. However, what is worrying is that the changing dynamics of the time makes a second look at the stool quite significant. It must be noted that the stool as a symbol can be very useful in guiding people through the necessary choices and changes that come with late modernity, by keeping them united and reminding them of traditional ethical values of the society. But it can only do those things as long as the stool itself is relatively unchallenged. This indeed is the challenge this study seeks to address. In the eyes of many anti-traditionalists, the stool and its associated symbols have been rendered as oppressive and hegemonic in contemporary era. Corrupt and other scandalous activities of some of the chiefs which are at odds with the religious and spiritual position of their office make people wonder if indeed the position is as sacrosanct and unchallenged as it has been presented over the years.

In most cases, the religious field becomes the battlefield. It is here the sacred nature and position of the chief is constantly employed in the deployment of the authority of the chief. Subjects are compelled, covertly or overtly, to acknowledge the sacred position of the chief. Traditionally, the sacred office of the chief is institutionalized and internalized as a desirable and essential part of the social hierarchy. There is no need for resistance and subversion and it is, indeed, socially and religiously unacceptable to defile the chief by openly confronting his authority. Social sanctions associated with desecrating the authority of the chief are purely religiously motivated. Particularly in the societies far away from the reach the central governments, and even in centralized cities, the aggression with which agents of the chief carry out offensive defense of the sacred institution gives credence to the important role of religion in 
the dissemination of the sacralized concept of the office of the chief. This will be discussed in details later in chapter seven.

\subsection{Conclusion}

The Akan sacred chieftaincy institution evokes a compellingly ambivalent concept in contemporary society. This chapter has taken an overview of the importance and challenges associated with the symbol of the stool. I have established that the stool, the symbol of the chieftaincy institution, occupies an important place in the socio-political and religious ethos of the Akan. The chapter has demonstrated how ideas of important theorists such as Mircea Eliade and Clifford Geertz would engage the understanding of the sacred metaphors of the Akan stool that have been used as the basis of legitimacy of the chief. However, it was established that within virtually any society whose religious system the ideas of Eliade or Geertz can be used to construct, a further deconstruction of the elements of economic or class exploitation, using the theories of Antonio Gramsci can be used to deconstruct. In the chapter that follows, I address the sacred metaphors of the chieftaincy institution as is perceived by the Akan. 
CHAPTER III: THE RELIGIOUS FOUNDATION OF THE AKAN CHIEFTAINCY INSTITUTION

\subsection{Introduction}

This chapter gives a general synopsis of the traditional Akan chieftaincy institution and the religious foundations that seek to make the institution a sacred and formidable one. I will assess the various categories of chiefs, the criteria of nominating, selecting and enstooling chief, and, once enstooled, the role assigned to each categories.

\subsection{Indigenous Akan Religion}

Traditionally, the Akan society is religiously inclined. That religion is intricately intertwined with the socio-economic and political life of the Akan is not an exaggerated assertion. The very basis of the existence of the society is religious. As such, religion becomes an indispensable part of the traditional Akan's daily routine. In order to understand the nature of the indigenous Akan religious tradition, it is important, first, to understand the Akan notion of what religion is. It must be said that the Akan concept of religion does not, in the strict sense of the word, conform to the general western intellectual concept of faith in which one may decide to or not to be a part of the religious tradition. The Akan sense of religion goes deeper than that to encompass one's identity with, participation in, and self-fulfillment in the traditional system of thought. Several scholars of African society have already placed much emphasis on this claim. According to Sidney George Williamson, the traditional Akan religion "can be studied by means of an investigation into their religious institutions and the religious implications of their social structure. The result of such inquiry is not a theology or a philosophy, but an undifferentiated number of rites and practices, enunciating beliefs which are statements and not creedal 
formulae. ${ }^{94}$ It is therefore fruitless to subject the Akan religion to any theological enquiry since, as Williamson indicated, the religion itself is not so much concerned with offering a thoroughly expounded theological doctrine. ${ }^{95}$ Thus, unlike the western religion, the Akan religion is a religion of institutions and practice with low or no emphasis on creed, if any. As Peter Sarpong has observed, in Ghanaian communities, of which the Akan are a greater majority, religion is everything. ${ }^{96}$ The Ghanaian, he noted, makes no distinction between his religion and his politics or administration of justice. Religion, Sarpong added, encompasses all aspects of the Ghanaian life, from cradle to the grave. ${ }^{97}$ As such there are certain religious rituals that are performed during every stage of life to mark such a transition in life. This belief forms part of the larger traditional African notion of religion and society which Mbiti persuasively wrote about. Mbiti claimed that the African is notoriously religious. ${ }^{98}$ Traditionally, he observed, religion entirely permeates into all the sectors of African life so that it becomes a difficult or an almost impossible task to separate the two. It can therefore be argued that no forceful amount of internal or external influence can alter such a worldview. As such, any discussion or "study of these religious systems is, therefore, ultimately a study of the people themselves in all the complexities of both traditional and modern life." ${ }^{99}$

\footnotetext{
${ }^{94}$ Sidney George Williamson, Akan Religion and the Christian Faith: A Comparative study of the Impact of Two Religions (Accra: Ghana Universities Press, 1959), 85.

${ }^{95}$ Williamson, Akan Religion and the Christian Faith, 86.

${ }^{96}$ Peter Sarpong, Ghana in Retrospect: Some Aspects of Ghanaian Culture (Tema: Ghana Publishing Corporation, 1974), 133.

${ }^{97}$ Sarpong, Ghana in Retrospect, 133.

${ }^{98}$ Mbiti, African Religions and Philosophy, 1.

${ }^{99}$ Mbiti, African Religions and Philosophy, 1.
} 
Religion is also essential in the formation of the Akan community. It is the basis of the moral community, "serving as a deterrent against aberrant behavior and an incentive to good conduct. ${ }^{, 100}$ Indeed, as J.B. Danquah compellingly argues:

the Akan cannot justify his religion as perfect or complete until he includes the whole of that which could claim ancestry from Odomankoma as also of the unified perfection. Akan religion therefore strives for its fulfillment upon the discovery by man, by all men, that they are made of one blood, are of the race of God, the Supreme Creator and final Ancestor. ${ }^{101}$

Thus, belief in one God, the supreme head of the society is essential, central and common to all indigenous Akan believers.

\subsection{Akan and the Worship of God}

Without a doubt, I cannot but agree with Williamson that linguistically speaking, the Akan has no particular word in their vocabulary for religions. ${ }^{102}$ Be it as it may, religion, to the Akan is loosely translated as som, a service or worship of a higher spiritual force. Som is the payment of allegiance, worship, service or commitment to a higher being, authority or force. The concept of som can be aptly typologized into the worship of God, deities, ancestors, and chiefs or any superior person. The Akan generally confirm an attitude of unconditional reverence for Onyankopon (literally, The Being that is Alone Great), the Supreme Being. ${ }^{103}$ Traditional Akan religion pays special attention to service (som) of God (Onyame) which is called Onyamesom. Although Onyamesom is today associated, quite erroneously, with only Christianity, it is a generic term used for any worship of God or the Supreme Being. The word changes a bit when

\footnotetext{
100 Sarpong, Ghana in Retrospect, 133.

${ }^{101}$ J.B. Danquah, The Akan Doctrine of God: A Fragment of Gold Coast Ethics and Religion, 2nd ed. (London and New York: Routledge, 1968), 169.

${ }^{102}$ Williamson, Akan Religion and the Christian Faith, 86.

${ }^{103}$ Kwasi Wiredu, Cultural Universals and Particulars: An African Perspective (Bloomington and Indianapolis: Indiana University Press, 1996), 46.
} 
dealing with Islam. The traditional Akan word for the worship of God in relation to Islam is Nyamefre, (Nyame, God and fre, call) and the practitioners are referred to as Nyamefrefor (literary, those who, foo + call, fre + God, Nyame). It must be pointed out that although Rattray claimed to have found a temple in honor of Onyame, the Akan, technically speaking, do not worship God in any specially designated temples or shrines. What Rattray found in the Asante compound of his day, and even some places today, was the Onyame dua, "a triple-forked branch set upright in the ground, serving as an altar."104 On this is a bowl that usually contains some concoction $^{105}$ or herbal medicine believed to protect every member of the family that uses it (especially in the morning to wash the face as a means of protection.

Because of the pervasive nature of religion in indigenous Akan societies, Sarpong observes that formal religious instruction, for example, is not traditional to the Ghanaian society. This observation finds its expression in the Akan proverbs that says obi nkyere abofra Nyame ("no one teaches the child about God or to know God"). The concept of God is taken for granted in the traditional ethos of the Akan. It is innate and obvious to everyone. According to Sarpong, "[A]s a child, his mother or father may reprimand him when he goes against what is thought to be the religious law of the land, especially taboos; but for the rest, he picks up imperceptibly the current religious ideas and practices from conversations, observations and active participation in religious activities." "106 Thus the concept of God is a very pervasive one and is fundamental to the religious beliefs of the Akan people of Ghana. As Asare Opoku puts it "God is generally regarded as the Overlord of Society and the Final Authority in all matters. He has power over life

\footnotetext{
${ }^{104}$ Williamson, Akan Religion and the Christian Faith, 87.

${ }^{105}$ Rattray, Ashanti Law and Constitution, 139-42.

${ }^{106}$ Sarpong, Ghana in Retrospect, 133.
} 
and death. ${ }^{, 107} \mathrm{He}$ is the just judge of the society. The helpless and defenseless Akan is usually found of saying mede m'asem ama Nyame (I have handed my case to God). He is all knowing and sees the secret deeds of the members of the community. He judges fairly and His power to judge and His interest in the moral affairs of the people goes beyond the grave. Indeed, God is said to be the source of all morality and it is the responsibility of the spiritual forces, especially the gods, who act as God's representatives, to make sure that these laws are enforced. ${ }^{108}$ It is for this and other reasons that the worship (som) of God is usually done through the gods.

\subsection{The Gods and the Moral Community}

The Akan concept of som is also extended to the worship of the deities. Indigenous Akan religious tradition believes that Onyame manifests himself through his agents or messengers, the deities, Abosom. The worship (som) of the deities (abosom) is called abosomsom. Abosomsom is the rituals and practices conducted in honor of the deities according to custom, either in private or in communion. The etymological meaning of the word is not definite within the academic circle. Some of the interpretations have been pejorative while others are still filled with a lot of intellectual uncertainty. According to A.B. Ellis, for example, abosom (singular, bosom) are originally malignant spirits, the producers of calamities. The term is derived from two Akan words bo (to form, create or make) and esum (misfortune, disaster, catastrophe). ${ }^{109}$ Ellis observed that the abosom can be good especially when "bribed by a valuable offering,... when propitiated by sacrifice and flattery." ${ }^{110}$ Ellis' notion has been rejected by some scholars as quite

\footnotetext{
${ }^{107}$ Opoku, West African Traditional Religion, 153.

${ }^{108}$ Opoku, West African Traditional Religion, 156.

109 A. B. Ellis, The Tshi-Speaking Peoples of Gold Coast of West Africa (Oosterhout N.B: Anthropological Publications, 1970), 12-13.

${ }^{110}$ Ellis, The Tshi-Speaking People, 10-12.
} 
spurious and overly exaggerated. According to Warren Dennis, who conducted extensive ethnographic studies on the abosom of the Bono of Techiman, for example, the notion that bosom is stone worship must be rejected. The word, he said, comes from Akan words som bo, that is, an object of valuable essence. ${ }^{111}$ That is, the Akan deities occupy a special space in the religious ethos of the people. Indeed, the Akan gods, like the deities of the then Gold Coast which Ellis observed, "are jealous gods, jealous of their dignity, jealous of the adulation and offerings paid to them, and there is nothing they resent so much as any slight, whether intentional or accidental, which may be offered them...there is nothing that offends them so deeply as to ignore them, or question their power, or laugh at them" ${ }^{, 12}$ Thus as moral givers and sustainers of the community there are certain behaviors that deities prohibit. As Opoku has observed, the Akan gods do not sit unconcerned about the most atrocious crimes for they punish offenders. ${ }^{113}$ Wrongdoings are said to frustrate the good relation and the harmony that must exist between the gods and the people. Busia for, example, enumerated some of the prohibitions which the deities abhor greatly and the reasons for reasons behind them. ${ }^{114}$ Members of the community who flout the instructions of the gods are believed to be swiftly punished while those who adhere to their code of behavior receive blessings of good life, the gift of children, good harvest, etc.

\footnotetext{
${ }^{111}$ Warren M. Dennis, “Bono Art Shrine,” African Arts 9, no. 2 (January 1976): 28-34.

${ }^{112}$ Ellis, The Tshi-Speaking People, 11.

${ }^{113}$ Opoku, West African Traditional Religion, 157.

${ }^{114}$ K. A. Busia, The Position of the Chief in the Modern Political System of Ashanti: A Study of the Influence of Contemporary Social Changes on Ashanti Political Institutions. (London: Frank Cass and Co. Ltd., 1968), chapters $4 \& 7$.
} 


\subsection{The Place of the Ancestors}

The specific role of the ancestors in relation to som has been a subject of intense scholarly debate. For most scholars, the concept of ancestor worship in the context of Africa is erroneous because the ancestors are only revered and not worshipped in the strict sense of the word. In his discussion on the various kinds of veneration accorded the ancestors, Sarpong argued that he does not believe that the ancestors of Africa are worshiped and rather prefers to use the term veneration. He argued that in the context of Africa, the Ghanaian, for example, "does not worship his ancestor as Christians worship God or Moslems Alla. He venerates them, honours them and respects them, and this deferential attitude occupies a big part of his religious life." 115 While this section does not seek to engage in this debate, it is important to mention that throughout this paper, I argue that, depending on whatever motive the believer has, the ancestors are both worshipped and venerated in every sense and meaning that the rituals of the believer evoke. As important spiritual forces who also serve as moral lawgivers of the community, there is nothing offensive in receiving the worship of their adherents. Again, it is not clear if any convincing data exist to demonstrate that, at the popular level (an important determining factor in making religious claims) when believers meet alone or in private to offer sacrifice or perform the occasional rituals and ceremonies to the ancestors, they make any conscious distinction between what is worshipped and what is venerated.

Whatever the correct terminology is, it must be said that Akan traditional society is also highly characterized by a profound reverence for ancestors and tradition. Respect for tradition, mostly to be associated with ancestral heritage, is an essential part of the traditional Akan. In most cases, reasons for not breaching a particular social norm is because $\varepsilon$ firi tete (it's been there

\footnotetext{
${ }^{115}$ Sarpong, Ghana in Retrospect, 42.
} 
since time immemorial) - since the era of the ancestors. Traditionally, the Akan ancestors can be grouped into three categories. The first categories are the family ancestors. The second group are the town or village ancestors and the third and most important group of ancestors are the state or ethno-tribal ancestors. ${ }^{116}$ The third group of ancestors is the royal ancestors who occupied the highest position in the state before their departure from the land of the living. The ancestors are said to be in constant touch with members of the community. They continue to take interest in the affairs of the living. ${ }^{117}$ Owing to their important position, frequent and occasional rituals are performed in their honor. Much emphasis will be placed on the ancestors throughout this study.

\subsection{Succession/Inheritance}

Among the Akan, descent is traced through the matrilineal line. A chief is chosen from the royal family of the mother's side. Thus, a son, for example, cannot succeed his father to the throne. Only his sister's son can succeed him. To become a chief requires certain traditional processes that one needs to undergo.

The first most important constitutional recognition of the chief is the acceptance and recognition of the custom of the area where the person is a chief. Under the laws of the country, a person is considered a legitimate chief if there is a clear evidence of proper establishment of his customary position. By this, the person is so considered if he was validly nominated, selected and installed as a chief in accordance with the customary laws of the land. The 1992 Constitution demands that in addition to these customs, the name of the chief has to be gazetted, that is, his name must be entered into the National Register of Chiefs. Indeed, no one can validly function as

\footnotetext{
${ }^{116}$ For a good understanding of this typology, see Patrick Ryan, "Is it Possible to Construct a Unified History of Religion in West Africa?," Universitas 8 (1984): 98-110.

${ }^{117}$ K. A. Busia, "The Ashanti of the Gold Coast," in African Worlds: Studies in the Cosmological Ideas and Social Values of African Peoples, ed. Daryll Forde, Reprint. (Munster-Hamburg: International African Institute, 1999), 207.
} 
a chief unless his name has been entered in the said register. It is constitutionally mandated that the status of the new chief must be recognized by the government or be published in the Local Government Bulletin or the Chieftaincy Bulletin before he can so function as such. Act 759, s57 (5) spells this out clearly. "A person shall not be considered to be a chief for the performance of a function under this Act or any other enactment, unless that person has been registered for the performance of that function in the National Register of Chiefs and that person's name has been published in the Chieftaincy Bulletin." Over the years, this has been a subject of dispute. This will be explored in chapter seven.

Traditionally, the Akan method of succession to the stool is not done arbitrarily. It is by "selective democratic procedure." 118 It is carried out by kingmakers of the society after a careful consultation with the spirits of the departed rulers. ${ }^{119}$ Both tradition and even the 1992 Constitution recognize four most relevant procedures in this process. The first procedure is the qualification of the candidate, that is, he or she must hail from the appropriate royal family within the ruling lineage. It must be reemphasized that Akan traditional societies, like most ethnic groups in Ghana, are such that in most communities, there may be two or several family groups all of whom trace descent from a common ancestry. Where there is more than one qualifying royal family, the method of succession is usually rotated.

The second most important procedure is the nomination of the chief. Once it is properly determined, out of a list of royal candidates, who might all be qualified the right to nominate the appropriate person to be chief lies in the power of the queenmother. ${ }^{120}$ The queenmother must

\footnotetext{
${ }^{118}$ Brobbey, The Laws of Chieftaincy in Ghana, 143.

${ }^{119}$ Mbiti, African Religion and Philosophy, 179.

${ }^{120}$ Literally, the female king/chief.
} 
satisfy herself with the conviction that her eligible candidate is without any questionable character qualities discussed earlier. Once she is satisfied, an official announcement is made to the kingmakers.

Third, after the queenmother's nomination, the suitability of the candidate is determined. This suitability is determined through election. The election is made by the kingmakers of the land. Just as the queenmother reserves the right to nominate a candidate, so also the kingmakers have the right to accept or reject such a candidate. After a thorough background check and scrutiny, the kingmakers accept or reject such a person. This process, in most cases, presents an odious task to the elders. Conflict and disagreement, corruption and dissatisfaction usually erupt at this stage. Depending on the area, such selection is done either publicly or privately. As Brobbey has observed, the public selection has the potential of increasing corrupt practices in the process. According to him, while such a forum allows transparence, and obviously democracy, it is replete with increasing chieftaincy expenditure considering the number of people who have to be influenced by the candidate in order to win their support. ${ }^{121}$ It must be said that once the candidate has successfully undergone the scrutiny and has been agreed upon by the elder he is "arrested" and installed as a chief.

The fourth procedure is the installation. During this period the general public is given the opportunity to be an essential part of the process. It is the period in that the new chief swears to his people and the ancestors of the land. In the case of a divisional chief, he or she (the role of the female chief will be discussed shortly) swears an oath of allegiance to the Omanhene (paramount chief) after swearing to elders and the people.

${ }^{121}$ Brobbey, The Laws of Chieftaincy in Ghana, 148. 
It must be pointed out that an act short of these procedures is the basis for animosity and disaffection which usually calls for charges of destoolment and chieftaincy disputes in the society many of which turn violent even deadly.

\subsection{Categorizations of Chiefs}

Among the Akan, the belief is that no one person can form a nation and one man does not rule a nation (obaako mmu oman). The Akan also believe that one head does not go into council ( $t i$ koro nko agina). The formation of the state and the governance of it is a shared responsibility. The chief, as leader of the society is supported by other sub-chiefs whose role in the administration of the society cannot be taken for granted. Per the custom of the Akan, the categories of chiefs are the paramount chief, divisional chiefs, sub-divisional chiefs, adikrofo.

\subsubsection{The Paramount Chief (Omanhene)}

The paramount chief occupies the highest position in every traditional area. Among the Akan, with the exception of the Asante, the paramount chief ranks over and above all other chiefs and he is the leader and head of the traditional state. ${ }^{122}$ As per the 1992 Constitution and section 58 of Act 759 the Asantehene ranks above the paramount chiefs. He is the president of the Ashanti Regional House of Chiefs and the head of all the paramount chiefs in within the Asante "state."

Traditionally, the paramount chief is considered as the owner of the traditional area. Among the Akan, the paramount chief is often times addressed as asase wura. ${ }^{123}$ The common title "Omanhene" (oman, traditional state, and hene, chief, king) is indicative of this claim. The oman of the Akan is composed of several individual chieftaincy authorities in a particular

\footnotetext{
122 S. A. Brobbey, The Law of Chieftaincy in Ghana: Incorporating Customary Arbitration, Contempt of Court, Judicial Review (Accra: Advanced Legal Publications, 2008), 49.

${ }^{123}$ Asase wura (asase, land, earth, soil, planet and wura, owner).
} 
area. ${ }^{124}$ All divisional chiefs swear oath of allegiance to the paramount chief. The position of the paramount chief has constitutional and legal support. Per custom and articles 271 and 273 of the 1992 Constitution, the position of the membership of the National House of Chief, the highest decision making body of the chiefs in the country, the paramount chief is ranked as over and above the rest of the chief. This is also supported by section 49 of Act 370 and sections 13 (1) and 58 of Chieftaincy Act (759) of 2008.

\subsubsection{The Queenmother and her Role}

In order of importance, in the Akan political hierarchical order, the next most important person after the paramount chief is the queenmother. She is the Ohemaa (female chief/king) of the area. Her status as the Obaapanyin (from obaa, female, woman, and panyin, elder) puts her in a glorified position of not only the female members of the ruling class but also all members.

125 The term queenmother has, over the years, generated a lot of the academic disagreement. For some scholars, the term especially as used by early writers such as Rattray is misleading. According to Arhin Brempong (a professor and a chief), for example,: "The ohemaa of the state or division is wrongly translated, since Rattray as the 'queenmother' an importation from European monarchical institutions wherein a queenmother is either the mother or wife of a monarch."126 I personally find this debate over the correct terminology of the "queenmother" quite interesting. Though the queenmother occupies a particularly important religio-political role in Akan society little attention has been paid to it.

\footnotetext{
${ }^{124}$ Brobbey The Laws of Chieftaincy, 50.

${ }^{125}$ Brobbey, The Law of Chieftaincy in Ghana, 67.

${ }^{126}$ Arhin Brempong, Transformations in the Traditional Rule in Ghana (1951-1996), 1st ed. (Sedco Pub Ltd, 2001), 121-2. See also Brobbey, The Law of Chieftaincy in Ghana, 68.
} 
Owing to the special role of women in the religio-social history of the Akan, some have argued that the Akan political system better fits the description of covert gynocracy. ${ }^{127}$ According to the theory of gynocracy, despite the crucial role played by women in the religiopolitical setup of Akan society, little attention, over the years, has been paid to them in both popular and academic discourse. Even at the traditional political level, female leaders are given a backstage position. As Lynne Brydon has pointed out, "In spite of this pivotal genealogical role for women, however, women were historically only the conduits as sisters and mothers of brothers and sons through which entitlement to office holding and property passed. Men held the offices and managed the property, whether land or other forms of wealth." ${ }^{128}$ Historically, the office of the queenmother was ignored by the British colonizers, and generally bypassed by both early and present nationalist leaders. ${ }^{129}$ Odotei, for instance, has outlined some compelling reasons for the subordination of women in the society in spite of women have been found to have occupied various positions as queenmothers, priestesses, and even warriors. She established the relationship between the contact with Europeans and the erosion of the power of women. She argued that the power and authority of pre-colonial women were given the recognition they deserved until the ear of colonialism. Colonialism and its western fundamental norms of male supremacy, she argued, undermined the indigenous system and robbed women of much of what they had. ${ }^{130}$ Trade relations established between the pre-colonial Europeans and the indigenous

\footnotetext{
${ }^{127}$ Fiona Araba Gibson, "The Akan Queen Mothers in Ghana and the Implications of Covert Gynocracy" (PhD Thesis, unpublished: University of Wales, 2010), v.

${ }^{128}$ Lynne Brydon, "Women Chiefs and Power in the Volta Region of Ghana.," Journal of Legal Pluralism and Unofficial Law, no. 37-38 (1996): 227-247.

${ }^{129}$ Beverly J. Stoeltje, “Asante Queenmothers: Precolonial Authority in a Postcolonial Society,” Research Review 19, no. 2 (2005): 1-19.

${ }^{130}$ Irene K. Odotei, "Women in Male Corridors of Power," in Chieftaincy in Ghana: Culture, Governance and Development, ed. Irene K. Odotei and Albert K. Awedoba (Accra: Sub-Saharan Publishers, 2006), 82.
} 
people, according to Odotei, was another contributory factor for the erosion of the power of women leaders. The trans-Atlantic slave trade, for example, created fear and instability as well as wars. The insecurity and wars generated by the slave trade necessitated the restructuring and realignment and expansion of existing political entities which subsequently led to the erosion of the authority of women leaders. "As states became more militarised, power tilted in favour of men."131

Notwithstanding this, colonial ethnographers such as R. S. Rattray, who became interested in the role of women in the Akan political system gave, detailed accounts of the significant place of women in the society. In his Ashanti, Rattray brought to light the prominent place of women in the society. ${ }^{132}$ In all these accounts, however, much attention was not placed on the political office of the female leader. The role of these prominent women was treated only in the light of the "pivotal genealogical role of women." For example, according Rattray, owing to the matrilineal, - "the mother right" system of descent, female king occupies a significant office in the society. Thus, the status of women is enhanced only in relation to men. They do not, as Lynne has argued, automatically, have status in their own right as persons. Commenting on Rattray's analysis of the role of women, Lynne observed that the parameters of women's importance in Asante society and their 'importance' as discussed by Rattray is given only a passing comment without any in-depth discussion on it. Women, according to Lynne, "are mentioned only as consorts or mothers or the participants or officiants in life-crisis rituals: they are not the policy makers, diplomats or generals of Asante society."133

\footnotetext{
${ }^{131}$ Odotei, "Women in Male Corridors of Power," 82.

${ }^{132}$ R. S. Rattray, Ashanti (Oxford: Clarendon Press, 1923), 78-9.

${ }^{133}$ Brydon, "Women Chiefs and Power in the Volta Region of Ghana.," 229.
} 
What is fascinating about this is that while globalization, modernity, international human rights, religious pluralism and other factors, as will be argued later, have challenged the chieftaincy institution in general, it rather has enhanced the position of the "female chief" "More recently, however, globalization has discovered them, and external sources are beginning to seek them out for local projects. Yet, queenmothers continue to face serious obstacles as a precolonial female authority in a postcolonial society.," $" 134$ Stoeltje writes. Contemporary queenmothers have been conscious of their role in bringing to life images that express key concepts in the culture. They are conscious of their significance as female leaders. ${ }^{135}$

A cursory look at the office indicated that the Akan queenmother, indeed, is an important feminine figure in the society. As has been indicated in chapter two, in traditional Akan cosmogony, each clan was founded by a common putative ancestress. ${ }^{136}$ The matrilineal system of the Akan is such that women have, for a very long time, been recognized as leaders of the society. Busia, for instance, has opined in ancient times the queenmother was the overall leader of the community but delegated powers to the male chief who acted on her behalf. ${ }^{137}$ The queenmother, according to Danquah, is seen not only as a mother of the state but also as an aunt, sister etc. As Danquah observed:

The queenmother or ohemaa in the Akan system is either a mother, aunt, sister or cousin to the reigning Omanhene or Ohene, who has been duly elected to and installed in that office by the same people who elect and install the Omanhene or Ohene. She is a recognized head of the Royal family, she owns a stool herself. She is the nominal chief of all women in the state. She sits in council on the immediate left of the Omanhene... ${ }^{138}$

\footnotetext{
${ }^{134}$ Stoeltje, "Asante Queenmothers," 1.

${ }^{135}$ Stoeltje, "Asante Queenmothers," 1; Odotei, "Women in Male Corridors of Power," 83.

${ }^{136}$ Nana Abayie Boaten I, "The Changing Role of Queenmothers in the Akan Polity," Research Review 8, no. 1\&2 (1992): 90-100; Odotei, "Women in Male Corridors of Power," 82.

${ }^{137}$ Busia, The Position of the Chief.

${ }^{138}$ J.B. Danquah, Akan Laws and Customs, 27, quoted in Brobbey The Laws of Chieftaincy, 67-68.
} 
Danquah's view has been carried out and developed by Meyerowitz. In both her The Akan of Ghana: Their Ancient Beliefs and The Sacred State of the Akan, Meyerowitz argued that ancient Akan regarded their queenmothers not only as important socio-political leaders, but also as sacred feminine figures, Mother-Moon goddess - the daughters of the Moon - symbolizing the female aspect of Nyame, the Supreme Being. According to Meyerowitz, in those days and time, the Akan, especially the ancient Bono of Techiman, were ruled by queenmothers. As such "the queen-mother was once the supreme war-leader" 139 and had a moon cult dedicated to her. Meyerowitz made similar compelling argument in her Divine Kingship in Ghana and Ancient Egypt. However, these claims have been challenged as overly exaggerated. Warren Dennis, who did similar ethnographic work among the people of Techiman, observed that nowhere in his extensive fieldwork did he come across any proof of Meyerowitz's claim; not even among "the fourteen outstanding historians nor the queen-mother, Afua Abrafi, nor a large number of priests has ever heard of a time when women in general ruled...Nor does anyone realize that the queenmother's soul (kra) comes from or ever came from the moon, nor that Nyame (God) has ever been connected with the moon."140

Be it as it may, it must be pointed out, however, that as daughters of the gods, they were seen as the repository of traditional wisdom and the secrets of the society. Due to the matrilineal nature of the Akan lineage, queenmothers have, over the years, been crucial in the running of the society. Traditionally, because of their experience and wisdom of the secretes of the society, problematic and delicate decisions are taken only in consultation with the aberewa ${ }^{141}$ to seek

\footnotetext{
${ }^{139}$ Eva L. R. Meyerowitz, The Akan of Ghana: Their Ancient Beliefs (London: Faber and Faber Limited,, 1958), 31.

${ }^{140}$ Dennis M. Warren, A Re-appraisal of Mrs. Eva Meyerowitz's Work on the Brong, Research Reports, n.d., 56.

${ }^{141}$ In chapter three it was indicated that owing to their old age and experience, these elderly are too experienced to be ignored. Aberewa, the famine form of akokora discussed earlier, is consulted in times of tougher decisions.
} 
their counsel. The traditional expression, yenko hunu abrewaa (let us consult the old lady) explains this. "The word Abrewa did not just mean an old lady, in this context it meant the Good Old Lady. She was referred to as 'good' because she was always able to give very good counseling leading to amicable settlement of issues for which men counsellors alone often messed up, sometimes leading to unrest and wars in the olden days." ${ }^{\prime 142}$ What is interesting even in contemporary times is that though, in most cases, the symbolic practice of asking the old lady is usually done by men without consulting any old woman, the name and the concept still remains unchanged. This and other events in the traditional society provide evidence of the fact that as Odotei has rightly argued "the corridors of power cannot be seen as exclusive male preserves. They are open to both men and women."143

It is most significant to mention that both the 1992 Constitution and other supporting legal documents put the queenmother at par with the chief. In view of the interpretation of section 48(1) of Act 370, the queenmother is regarded as a chief. ${ }^{144}$ This view is also supported by article 277 of the 1992 Constitution. The queenmother presides over the tribe in case the stool becomes vacant (following the death, destoolment, or retirement of a chief until a new one is selected). As has been indicated earlier, the queenmother names a new chief also, in consultation if her elders, has the power to dismiss the chief, as well. As a result of her important role, the criteria for the qualification of a queenmother are the same as that of the chief. These criteria will be discussed in subsequent discussion.

\footnotetext{
${ }^{142}$ Nana Abayie Boaten I, "The Changing Role of Queenmothers in the Akan Polity," 90.

${ }^{143}$ Odotei, "Women in Male Corridors of Power," 81.

${ }^{144}$ Brobbey, The Law of Chieftaincy in Ghana, 69.
} 


\subsubsection{The Divisional Chiefs (Abrempong/Abremponfo)}

Next to the paramount chief are the divisional chiefs, known as the abrempong. It is not quite clear how the word originated. However, I do agree with Rattray that: "It may be derived from 'barima (a man), and pon (big), or its root may possibly be bremo (backbone) and pon." assumptions make sense in the light of their position and function in the society. From the first assumption, it is clear that as "big men," the abrempon wield considerable power and influence in the society. Secondly, seen as "backbones" the abrempon function as the main pillars - the foundational agents and elders who support the paramount chief of the area. They are, in turn, assisted by the sub-divisional chiefs.

\subsubsection{Sub-divisional Chiefs}

Below the divisional chiefs are the sub-divisional chiefs. They are:

The Adikrofos (Headmen)

The adikrofos follow the sub-divisional chiefs in rank. The origin of the word is quite easy to locate. They are believed to be the leaders of the various towns and villages ( $d i$, to lead $+k r o$, town village, foo, those who). They are the various representatives of the abrempon. As such, as Brobbey observes, they are seen as the supervisors or caretakers of the various villages and towns they represent. ${ }^{146}$

\subsubsection{Council of Elders}

A good majority of the people of Akan, traditionally, live in the family villages. Such villages are mainly ruled by what Field referred to as "a democratic gerontology governed by a council of

\footnotetext{
${ }^{145}$ Rattray, Ashanti Law and Constitution, 94.

${ }^{146}$ Brobbey The Laws of Chieftaincy, 51.
} 
elders. ${ }^{\prime 147}$ These rulers are mainly composed of head elders (abusua panin) of various kingship groups of the society. The head of the council of elders presides over the meeting of such group.

\subsection{Conclusion}

This chapter has attempted to instill an understanding of Akan traditional society, its historical, geo-political and religious systems and how these have relevance for the chieftaincy institution. In the chapter that follows, an attempt will be made to delve into the sacred nature of the Akan chieftaincy institution and how this belief has come to be historically dominant within the religio-political ontology of the Akan people.

${ }^{147}$ M.J. Filed, Search for Security: An Ethno-Psychiatric Study of Rural Ghana, (New York: The Norton Library, 1960), 23. 


\section{CHAPTER IV: THE METAPHORS OF THE AKAN SACRED CHIEF}

\subsection{Introduction}

This research is particularly concerned with how images of the sacred and the profane are translated in the office of the Akan chief and its implication for religious human rights of the individuals. In this chapter, I concentrate particularly on the visions of sacred metaphoric representation of Akan chief from historical and ideological points of view. With this, two important issues will be dealt with: the mythic historicity of the sacred nature of the Akan chief and the ideological foundation of this concept. The chapter demonstrates that while the mythic historicity of the concept of sacrality gives the chieftaincy institution a divine and spiritual basis, the ideological justification is used as symbolic mechanism of not only seeking to subordinate all to the position of the chief but also rallying all ethnic members together around the personality of the chief.

\subsection{The Sacralization of the Akan Chief}

It has already been established in chapter two that the Akan traditional cosmology believes in three major interrelated arms of authority or power of governance in society: the spiritual forces, the religio-political leaders or rulers, and the citizens. It was indicated that although each of these power structures of society is independent, they also overlap for the smooth functioning of day-to-day governance. This notwithstanding, I indicated that the Akan chief is politically the single most important of the three sources of power. In the personality of the chief is found union of the powers of both the spiritual and the physical forces of the Akan society. The chief is therefore a sacred person. His sacrality is masked in the mythic history of the community. 
The aura of sacrality associated with the chief is embedded in the historicity of the chiefly office which is linked to the ancestors of the land whose stool the chief occupies. Traditional Akan chieftaincy institution is mostly based on the kingship system. Under this, the head of the family who is also the leader of the community is said to have derived his position from the link between the living and the departed ancestors who are also themselves the founders of the kingship group. ${ }^{148}$ As has been argued earlier, though briefly, the Akan chief is held in high esteem not because he is a chief but because the position he occupies is a sacred position. He is the glue that attaches the people to the ancestral traditions of the land. Hence, his office is a combination of the mystical and religious position. The office is the sacred repository of several centuries of Akan philosophical wisdom, religious values and socio-political worldview. It is the embodiment of prosaic and sacred activities of the society. The metaphoric representation of the chief's personality has been likened to some of the mystical titles within world religions. Nana Kobina Nketsia V, a traditional ruler and professor of history, has observed that even the common title, Nana, associated with the Akan chief, is a religious one that is comparable to the Buddhist concept of the Bodhisattva. ${ }^{149}$ The concept of Nana, he said, is similarly connected to "the purity of saints and also refers to a God-like existence. Nananom emanate a positive flow of energy from their space to the space of manifest existence in the perduring now." ${ }^{" 150}$ Nana is a symbolic representation of the sacred personality that the chief, by virtue of his enstoolment, has

\footnotetext{
148 Abraham Akrong, "Religion and Traditional Leadership in Ghana," in Chieftaincy in Ghana: Culture, Governance and Development, ed. Irene K. Odotei and Albert K. Awedoba (Accra: Sub-Saharan Publishers, 2006), 197.

${ }^{149}$ Especially in Tibetan Buddhism, a Bodhisattva is the one who after striving to achieve nirvana (enlightenment), which is the ultimate goal of the believer, decides to help others attain same out of pure compassion and love.
}

See Nana Kobina Nketsia V, "The Ancestor and Nation-Building: Aluta Continua," http://www.kasbenin.de/ghana/Nana Nketsia Ref-Ancestors and Nation.pdf; [accessed December 4, 2009].

${ }^{150}$ Nketsia V, "The Ancestor and Nation-Building," 
assumed. It is a title that "legitimizes his status as a de jure ancestor, who has the mandate of the ancestors to rule the people on their behalf..."151 The chief, therefore, is the central figure within the traditional society of the Akan religio-political and social system. The sacrosanct position of the chief evokes a sense of awe. Since the ancestors occupy a very special place within the religious ontology of the Akan, the position of the chief, by extension is a very crucial and significant one. According to the Catholic Archbishop (emeritus) and anthropologist, Peter Sarpong, the ancestors of the Akan are quite synonymous with the Christian saints. As such “[W]hen Christians call their dead saints and refer to those of pagans as ancestors, they are not expressing different ideas. Both words express ideas about people who once belonged to their religious groups, are now dead, and are supposed to be in a position of influence over the living." $" 152$ The sacrality of the chief, as Apter has shown, makes him have:

a monopoly of age; that is to say, in a system where age provides certain prerogatives, the chief is called nana or grandfather. This is both a token of his family-inspired role and a symbol by which the equation between age and wisdom can be conferred on him, regardless of his actual age. The patriarchic title is thus conferred even though the chief may be a young man. ${ }^{153}$

Apter's account thus reveals how traditionally old age is associated with wisdom. One therefore sees a metaphoric representation of the chief as the wise one. The old person, by virtue of his or her age, is considered more experienced in life. He or she has more knowledge of the culture, values, philosophy, mores, norms and above all the traditional history of their people. Theoretically, the old do not err. Whatever they say is the truth. ${ }^{154}$ It is traditionally unethical to

\footnotetext{
${ }^{151}$ Akrong, "Religion and Traditional Leadership in Ghana," 198.

${ }^{152}$ Sarpong, Ghana in Retrospect, 33.

${ }^{153}$ David E. Apter, Ghana in Transition (Princeton \& New Jersey: Princeton University Press, 1972), 106.

${ }^{154}$ See Sjaak van der Geest, "Opanyin: The Ideal of Elder in the Akan Culture of Ghana," Canadian Journal of African Studies 32, no. 3 (1998): 449-493.
} 
challenge or openly confront the old. In most cases, it is not uncommon to find older people whose words and actions are challenged but are later proved to be right usually retorting "when your grandparents tell you something do you need to go and confirm it from your parents?" This observation is an obvious indication that by virtue of their age, they are too experienced to be challenged. Their old age gives them the privilege of being closer to the ancestors, whose actions and activities are unchallengeable. The best, and perhaps the clearest explanation of this is given by van der Geest. Akan elderly people, according to Geest, "are ancestors in spe. They hope to be remembered as honorable ancestors after their death and therefore attempt to behave accordingly during their old age." ${ }^{155}$ Geest described the Akan etymological stages in life as:

Abarima-wa is a small man. He grows to become aberantee, young man. Wobra a onte ("when you stop him, he won't listen"). It is the age when men feel that what they are doing is right and therefore refuse to take the advice of elders. The young man grows to become an old man, akwakora. It is the time he is near his grave. He can be buried at any moment. To bury someone is kora or sie, which means "to hide." skokora means: he is going to hide. So after the akwakora stage in life follows the burial. ${ }^{156}$

The concept of akwakora (old man) or aberewa (old woman) is sharply comparable and also contrasted with opanyin. While akwakora/aberewa and opanin are used to address old people, the former is more of an achieved title ${ }^{157}$ rather than honorific one. Thus old age is the deciding factor in the case of the former. As Geest explained, while both are usually used interchangeably, the "only exception is when someone is given a stool in the chief's palace such a person will be called opanyin, even when he is still very young. ${ }^{158}$ Thus though the title, opanyin, can be

\footnotetext{
${ }^{155}$ Geest, “Opanyin,” 452.

${ }^{156}$ Geest, “Opanyin,” 454.

${ }^{157}$ I do not intend to engage in the sociological controversies regarding the thin line between what is achieved and what is ascribed especially in traditional societies. For a good understanding of the difference between the two and the controversy these terms have generated over the years, see Irving S. Foladare, "A Clarification of "Ascribed Status' and 'Achieved Status',” The Sociological Quarterly 10, no. 1 (Winter 1969): 53-61.

${ }^{158}$ Geest, “Opanyin,” 455.
} 
achieved, in the context of the one enstooled as a chief, it is more ascribed, and as the American anthropologist, Ralph Linton, says, without reference to their innate differences or abilities. ${ }^{159}$ The source of power the chief wields in the society, I have already indicated, is derived from the tradition "coursed through the blood of his veins and was made manifest by election to office."160 Through "accident of birth"161 and by virtue of becoming a member of the ruling class or council of elders he or she is given an elevated title. Here age is not a deciding factor in eldership. For some observers like Ephraim-Donkor, this title, contrary to the claim made above, is rather achieved than ascribed. "Eldership therefore is a qualitative state of ethical existence and generativity. It is the ideal state of being, achieved after successfully integrating all successive periods of existence. It entails having lived an altruistically ethical life, and bequeathed to the matrikin folks a name that is worthy of remembrance and evocation." 162 The Akan use the maxim "the child who learns how to wash his or her hands well eats with the elderly" to support this claim. Traditionally, children and the elderly do not eat together. To be "privileged" to eat with the elders means that one has really learned how to wash one's hands well after soiling the hands with childhood dirt from playing on the ground. Similarly, the youth who has been elevated to the position of leadership in the society is considered as an elder hence the title opanyin. This title is based on the sacredness of his position. It is an elderly position. Thus opanyin, just as nana, is both a social and a sacred metaphoric title.

In the context of the title, Nana, nearly always, the prefix, nom, is added to it, so that one hears of Nananom (plural of Nana). Similarly, mpanyinfos is used to address more than one

\footnotetext{
${ }^{159}$ Ralph Linton, The Study of Man (New York: Appleton-Century-Crofts, Inc., 1936), 115-31.

${ }^{160}$ Apter, Ghana in Transition, 108.

${ }^{161}$ Foladare, "A Clarification of 'Ascribed Status' and 'Achieved Status'," 1.

${ }^{162}$ Ephraim-Donkor, African Spirituality, 127.
} 
elder. Traditionally, the two designations, Nananom and Mpaninfos, are combined to give a perfect title for the chief and his elders- Nananom Mpanyinfos. Nananon Mpanyinfos are the council of elders and, in the opinion of Ephraim-Donkor, are the enlightened ones who await transformation into ancestorship. ${ }^{163}$ Since the ancestors were once elders of the community, there is a close spiritual bond between them and the living elders. ${ }^{164}$ Thus, a similar pattern of sacred metaphoric representation of the chief is found in this designation. As already been indicated throughout this discussion, the office and person of the chief, among the Akan, represents a very central political unit. His personality has been consecrated to be the nerve of his society. ${ }^{165}$ As such nothing unclean must touch it. As sacred personalities of the traditional state, his office must be protected with sacred prohibitions. ${ }^{166}$ The chief must not only be protected by societal taboos, but must also posses certain qualities befitting his status. Potential heirs or candidates have to be physically perfect. ${ }^{167}$ Failure to meet these criteria has been the basis of most chieftaincy disputes in Ghana. The next section discusses some of the sacred prohibitions associated with the office of the chief.

\footnotetext{
${ }^{163}$ Ephraim-Donkor, African Spirituality, 129.

${ }^{164}$ For a good understanding of the criteria of becoming an ancestor among the Akan, see Sarpong, Ghana in Retrospect, 33-44; Ephraim-Donkor, African Spirituality; Busia, "The Ashanti of the Gold Coast"; Busia, The Position of the Chief.

${ }^{165}$ Apter, Ghana in Transition, p. 108.

166 Owusu Brempong, "Chieftaincy and Traditional Taboos: An Empirical approach," in Chieftaincy in Ghana: Culture, Governance and Development, ed. Irene K. Odotei and Albert K. Awedoba (Accra: Sub-Saharan Publishers, 2006), 213-30.

${ }^{167}$ Parrinder, "Divine Kingship in West Africa," 111.
} 


\subsection{Disability Taboos and Akan Chieftaincy Institution}

Traditionally the position of the Akan chief is the conglomerate of traditional law, philosophical values, religious beliefs and cultural practices of the Akan, among others. The sacred position of the chief demands that it must be free of contamination- nothing despicable come into contact with it. Among the Asante, for example, Thomas Lewin summaries the standard qualification to ascend the golden stool as:

An Oyoko shedye or royal, from Kumasi must be known for his ahoofe, or handsomeness, his anumuonyam, or personality, and his sbrapa, or good character. Esese obi a sbedi Asantehene ye obi a sw ahofe ne sbrapa. An Asantehene must be handsome, must have personality and must have a good character. No Asantehene may ever be touched by the knife. ${ }^{168}$

Among the ancient Bono of Techiman, Meyerowitz wrote that the kings were 'the mystical and religious heads, the divine symbol of their people's health and welfare. ${ }^{169}$ Their sacred body must be without any blemish and spotless. Meyerowitz recounted that owing to the blamelessness with which one must occupy the stool of the ancestors, during the ancient times, for example, any child who wounded a potential heir to the throne, even unintentionally, was condemned to death. ${ }^{170}$ Parrinder, following Meyerowitz's observation, wrote that: "Noble children have their heads massaged, a baby's bones being kept soft with hot towels, so as to produce a wide skull which is supposed to give greater dignity. The king's body is supposed to be soft and rounded like a woman's, and a rich velvety skin is produced by specially fattening food." 171

\footnotetext{
168 Thomas J. Lewin, Asante before the British: The Prempean Years, 1975-1900 (Lawrence: The Regent Press of Kansas, 1978), 115.

${ }^{169}$ Eva L. R. Meyerowitz, The Sacred State of the Akan (London: Faber and Faber Limited,, 1951), 28.

${ }^{170}$ Meyerowitz, The Sacred State of the Akan; See also Seth Tweneboah, "Religious Human Rights," 55.

${ }^{171}$ Parrinder, “Divine Kingship in West Africa," 112-113.
} 
In the olden days, disqualification based on physical disability was not subject to negotiation. The sacred office of the chief must not be contaminated with any physical impairment. To help understand this, I have chosen to single out the reign of Agyemang Prempeh I for analysis. The choice of his reign is quite purposive. His elicits some basic insights necessary for the understanding of the uniqueness and ambivalence of the Akan chieftaincy institution.

Among the Asante, the controversy surrounding the reign of Agyemang Prempeh I gives us a vivid picture of the physical taboo surrounding the throne. It is said that the death of Kwaku Dua II (who is believed to have died of smallpox after six weeks of enstoolment) in June 1884, created a power vacuum. His death threw the Asante nation into a four year civil war (18841888). Two eligible candidates, Yaw Atwenenboanna and Agyemang Prempeh, emerged. According to Lewin, notwithstanding the youthful inexperience of Agyeman Prempeh, the kingmakers found him to be an attractive candidate for the highest office. ${ }^{172}$ His closest rival, Atweneboanna, had carved for himself a life of "inquiring mind and a reputation for his distinguished oratory abilities which had been displaced before the Asantehene Mensa Bonsu's court." ${ }^{, 173}$ Atweneboanna was noted for his strong political astuteness, a quality several Asante politicians and kingmakers had noticed especially in village gatherings. ${ }^{174}$ Lewin gave a startling account of Atweneboanna's own family members. According this account, in the ensuing conflict that followed the power vacuum, Atweneboanna's own members showed complete lack of interest in supporting their royal. Lewin observed that "in spite of belonging to the royal group

\footnotetext{
${ }^{172}$ Lewin, Asante before the British, 113.

${ }^{173}$ Lewin, Asante before the British, 114.

${ }^{174}$ Lewin, Asante before the British, 114.
} 
of Kumasi, his family kept in the background throughout the election. They seem from the start to have had considerable misgiving about his candidacy." 175 With all these qualities why would the kingmakers and members of Atweneboanna's own family opt for an inexperienced youth, Agyemang Prempeh? On March 26, 1888, Prempeh was esntooled as the Asantehene.

An essential element in this whole decision was that Atweneboanna's own relatives were ready to abandon family allegiance and support a good course for the unification of the Asanteman (Asante nation). It must be noted that the people were increasingly aware of the catastrophic consequences of selecting an unfit candidate to occupy the golden stool, the throne of the ancestors and the soul of the nation. Notwithstanding Atweneboanna's experience and good sense of judgment in matters of tradition and custom, he was found to be morally weak. He was said to be "a womanizer and profligate." ${ }^{176} \mathrm{He}$ could not be trusted in matters of finance. "In 1883-84 he squandered a great deal of family and private investors' money in wild-eyed rubber trade and gold-lending schemes."

To prove to the ancestors and the people that they had not treated Atweneboanna unfairly, the supporters of Prempeh "generally made known Atweneboanna's physical defect which, by custom, prevents him from becoming an occupant of the golden stool. ${ }^{178}$ It is believed that the wise and experienced Atweneboanna, from childhood suffered from a neck disease. Though he no longer suffered it in his old age, the eye-catching and impossible to hide scar left

\footnotetext{
${ }^{175}$ Lewin, Asante before the British, 114.

${ }^{176}$ Emmanuel Akyeampong, "Christianity, Modernity and the Weight of Tradition in the Life of 'Asantehene' Agyeman Prempeh I, c. 1888-1931," Africa: Journal of the International African Institute, 69, no. 2 (1999): 279311. [Accessed: January 20, 2011]. http//: www.jstor.org/stable/1161026.

${ }^{177}$ Lewin, Asante before the British, 114.

${ }^{178}$ Lewin, Asante before the British, 115.
} 
on his neck was sufficient to disqualify him. ${ }^{179}$ It does not, therefore, come as a surprise that after the public announcement of this deformity most of his secret supporters and undecided politicians openly threw their support to the "blameless" and spotless Agyemang Premeph.

It is interesting to mention that Prempeh himself was not spared the issue of "disability" taboo. A major negative aspect to his candidature was that he was a light-skinned person. According to tradition, Okomfo ${ }^{180}$ Anokye, the spiritual architect of the Asante state, "had warned no 'light-skinned' royal should be appointed Asantehene, for that would lead to the collapse of the Asante. Insider and outsider accounts testify to the fact that Prempeh was lightskinned by Asante standards. ${ }^{" 181}$ This observation is a very significant and problematic one. Traditionally, light-skinned could mean either a person with fair color, a white person or an albino with the later being a quite probable impairment to ascend the throne of the ancestors. ${ }^{182}$ The question, of course, is not which of these descriptions fits Prempeh, or whether or not he was any of these. Whichever description is quite (in)accurate, Prempeh's ascension to the throne, if Emmanuel Akyeampong is to be understood, was a bad omen for the state. In the ensuing power struggle between Prempeh and Atweneboanna, as described earlier, many of the kingmakers (particularly from Mampong, Nsuta, Agona and Kokofu) had opposed his (Prempeh) candidature for the fear of the "demise of the nation because of a prediction by Okomfo (priest) Anokye."183 After an ensuing civil strife, Prempeh was crowned king of the Asante. Prempeh I,

\footnotetext{
179 Lewin, Asante before the British, 115. See also Akyeampong, "Christianity, Modernity and the Weight of Tradition," 283.

${ }^{180}$ Okomfo is the traditional priest of the society.

${ }^{181}$ Akyeampong, "Christianity, Modernity and the Weight of Tradition," 279.

${ }^{182}$ Albinos are considered as a disability that prevents one from leading the people. The recent killings of albinos in Ghana and parts of Rwanda for ritual purposes explains this better.

${ }^{183}$ Akyeampong, “Christianity, Modernity and the Weight of Tradition," 279.
} 
notwithstanding the initial fear surrounding his candidature, was able to turn this "disability" into a powerful strength for the unification of the Asante state. ${ }^{184}$ But was it to be a lasting success?

If indeed Okomfo Anokye's model was to be followed, then Prempeh's enstoolment, as already indicated, was, obviously, a departure from the prophetic oracle. It was against the will of the ancestors as it had the potential of ruining the Asante nation. On January 20, 1896, Okomfo Akokye's prophecy neared its fulfillment when, in the words of Kimble, "to the horror of the assembled Ashantis," under the pressure of the British forces, the occupant of the golden stool, the Asantehene, was taken prisoner, together with his relatives and some key members of his sacred office. ${ }^{185}$ Although the 1874 Treaty of Fomena ${ }^{186}$ had been in existence for over two decades, and had never been enforced by the British, the king and his elders were accused of breaching its tenets. Could this be a sheer coincidence that it happened during the reign of Prempeh I who was "red" and therefore "disabled" to occupy the stool? According to Tordoff, commenting on the candidature of Prempeh,

a great drawback to his candidature was the fair colour of his skin, since the election of a fair-skinned ruler would break one of the taboos said to have been imposed by Okomfo Anokye. This taboo had, however, been broken a number of times in the past-for example, by the succession to the Golden Stool in 1720 of Opoku Ware, one of the greatest of Ashanti kings, who had been popularly known as Opoku Korkor, 'the red.' 187

\footnotetext{
${ }^{184}$ Akyeampong, "Christianity, Modernity and the Weight of Tradition," 284.

${ }^{185}$ Under Governor Maxwell William, the king was taken together with his mother, the Asantehemaa, Yaa Akyaa, his father, brother, "two other close relatives, two linguists, the chiefs of Bantama and Asafu, and the Kings of Mampong, Offinsu, and Ejiso." See Kimbe, A Political History of Ghana, 296.

${ }^{186}$ The treaty signed between the Asante and the British government required the Ashanti, among other conditions, to recognize the independence of the southern states, pay an indemnity of 50,000 ounces of gold, to surrender control over Elmina and to all payments from the British for the use of forts. It also required the Asante to abrogate every alliance with neighboring states such as the Denkyera and Akyem. In addition, the asantehene agreed to withdraw his troops from the coast, to keep the trade routes open, and to halt the practice of human sacrifice.

${ }^{187}$ W. Tordorff, Ashanti under the Prempehs, $1888-1935$ (London: Oxford University Press, 1965), 26; See also Akyeampong, "Christianity, Modernity and the Weight of Tradition," 283.
} 
Whatever the case, "Agyemang Prempeh was bent on defying the prophecy that Asante would collapse under his reign, and he advocated non-resistance. He sacrificed himself to maintain the integrity of his nation."188

Related to the issue of disability regarding the stool is menstrual disability. Due to the sacred nature of the chief's office, it must not come into contact with things that are considered as "unclean." This form of disability will be discussed in the next section that deals with the stool as the symbol of the chief and the taboos associated with it.

\subsection{The Stool as a Symbol of the Chief's Authority}

Traditionally, among the Akan, the stool represents an important socio-political and spiritual symbol of chiefly authority. Any discussion on the Akan chieftaincy institution without reference to the stool and the taboos associated with it, according to Owusu Brempong, "is tantamount to breaking not only the spiritual reinforcement of the society, but also the total religious and moral fabric woven by the creator, the ancestors, deities and the supernatural beings." 189 The stool, in fact, is the summation and symbolic representation of the office and power of the chief. It does not, therefore, come as surprise that the office itself is metonymously referred to as the "stool." ${ }^{\prime 90}$ As Sarpong has noted, traditionally, the expression "to sit on the stool is used in reference to the chieftaincy institution, and it is only by sitting on the stool that the chief assumes sacred and priestly personality. ${ }^{191}$

\footnotetext{
${ }^{188}$ Akyeampong, "Christianity, Modernity and the Weight of Tradition," 287.

${ }^{189}$ Brempong, "Chieftaincy and Traditional Taboos," 213.

${ }^{190}$ Fortes, Kinship and the Social Order, 138; Sarpong, The Sacred Stool of the Akan, 26.

${ }^{191}$ Sarpong, The Sacred Stool of the Akan, 26.
} 


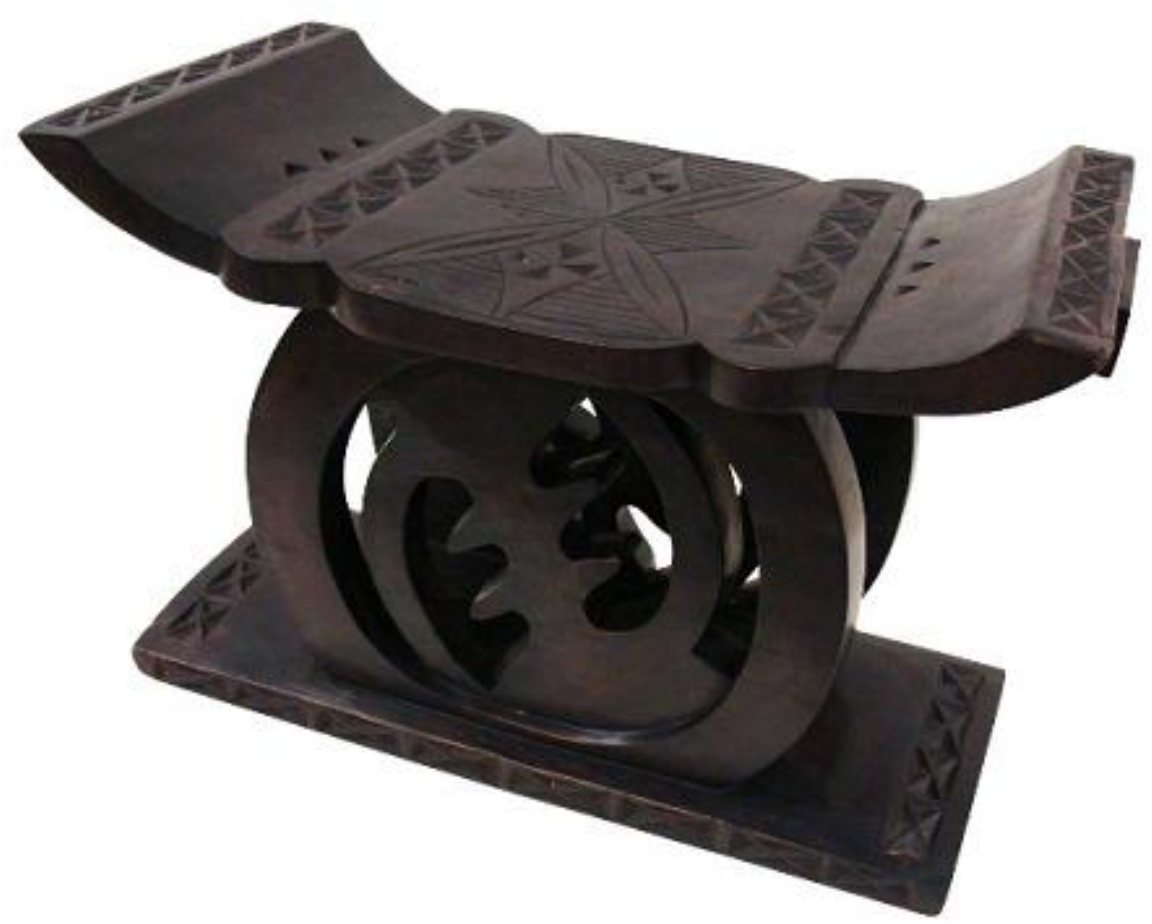

Akan Stool depicting the "Gye-Nyame" (Except God) Symbol"192

The stool also functions as the tribal symbol of memories and origin. It is a traditional image of tribal and ethnic solidarity. It is a unifying entity. Sarpong observed that the unifying influence of the stool is so strong that even a child is prepared to lead his people to war in defense of it provided that child could walk or talk. ${ }^{193}$ The stool evokes emotive concern among members of the same tribe or society. Enstoolment and destoolment cases have mostly been based on the candidates" lack of close connection to the "stool."

\footnotetext{
${ }^{192}$ See "African Wood Furniture: Ashanti Gye Nyame Sitting Stool from Ghana", Home Interior Design Themes at http://homeinteriordesignthemes.com/2009/05/african-wood-furniture-ashanti-gye-nyame-sitting-stool-from-ghana [accessed February 15, 2012].

${ }^{193}$ Sarpong, Ghana in Retrospect, 130.
} 
Although the stool has various functions within Akan traditional society, most scholarly attention has been focused on the political function slighting the other aspects of the stool. The stool, among the Akan, plays several significant roles. While "stool" has metonymously been associated with the traditional state and the sacred seat of the ancestors in particular, it must be said that until recently, a stool was found in virtually every traditional home of the Akan. It was seen as a utilitarian object in every household. ${ }^{194}$ Each and every individual (children, adults,) owned a stool in the family. ${ }^{195}$ Stools are designed to be sat upon, that is, they are seats. They are foundational. It is said that on should sit on a stool so that his or her buttocks must not touch the ground.

Secondly, the stool is a significant object during the rite of passage. During transition from one stage to the other, the stool is presented as gift and also as a symbol of successful transition. Although such a stool assumes an exceptional importance, its sacral elements or qualities are not emphasized. ${ }^{196}$ In most traditional homes, a child who successfully learns how to crawl is given a stool by the father to signify a great transition in its infantile life ${ }^{197}$ and a continuity with the eternal life that awaits him or her. Similarly, as part of the bragoro (rituals associated with Akan girl nubility rites) ${ }^{198}$ the girl is placed on the stool. This is done to signify that the girl has now attained the stage of womanhood. In most cases, during marriage ceremony,

\footnotetext{
${ }^{194}$ Sharon F. Patton, “The Stool and Asante Chieftaincy" 13, no. 1 (November 1979): 74-77+98-99.

${ }^{195}$ Sarpong, The Sacred Stool of the Akan, 17.

${ }^{196}$ Patton, "The Stool and Asante Chieftaincy," 74.

${ }^{197}$ Patton, "The Stool and Asante Chieftaincy," 74; Sarpong, The Sacred Stool of the Akan, 19.

${ }^{198}$ For a detailed understanding of the Akan girl's nobility ritual ceremony, see Peter Sarpong, Girl's Nubility Rites in Ashanti (Tema: Ghana Publishing Corporation, 1977).
} 
the man usually presents his new wife with a stool to symbolize the perpetuity of their marriage. ${ }^{199}$

According to Patton, the third and most important function of the stool is its sacred role in the family and in the society. According to him, in daily context of the traditional society the stool is "imbued with the being of its owner, as if the person's essence or spirit (sunsum) is absorbed into it upon each sitting. Consequently, the sacredness of the stool increases with contact with its owner; to prevent another person's sunsum from entering it, a stool is placed on its side when not in use. $" 200$ The stool is also used in ancestor veneration. In most traditional societies, the stool is placed in an obscure corner of the house where it is believed to be the abode of the family ancestor(s). The stool, thus, becomes the point of contact between the people and the ancestors, who seek to the welfare of the family and the society. ${ }^{201}$

At the spiritual level, stools are used as shrine furniture. In most shrines, the deities are placed on the stool as a symbol of the deity's authority. "Stools are also viewed as war medicine or as magical charms." ${ }^{202}$

A fourth and, obviously, most important function of the stool, (the concern of this discussion), is its religio-political symbol. Although some other tribes have been found to have used the stool, it is arguably said that of all the various cultures of West Africa, the uniqueness of the stool is peculiar the Akan. Quoting Kyeremanteng, Patton observed that the "stools are august emblems of political, judicial, and social leadership-'the most important of the chief's

\footnotetext{
${ }^{199}$ Patton, "The Stool and Asante Chieftaincy," 74; Sarpong, The Sacred Stool of the Akan, 17.

${ }^{200}$ Patton, "The Stool and Asante Chieftaincy," 74. See also R.S. Rattray, Ashanti, (Oxford: Clarendon Press, 1923:12), 298.

${ }^{201}$ Having outlined the various types of stools and their significance, all subsequent reference to the stool are used in relation to the seat of ancestors as it is normally understood in the society.

${ }^{202}$ Patton, "The Stool and Asante Chieftaincy," 74.
} 
regalia and the sine qua non of his high office." ${ }^{203}$ Owing to their unique spiritual and religious significance in the society, even tools used for the carving of the stool have to undergo some ritual cleansing before they are used. ${ }^{204}$ As an important relic in the religio-political life of the Akan people, the sanctity of the stool covers the carver as well; and he is, as such, also regarded in high esteem.

The stools used by the chiefs are categorized according to purpose as decided by the chief. ${ }^{205}$ There are domestic stools used for eating, bathing, etc and there are stools used in public ceremonies. ${ }^{206}$ Although all stools may appear ordinarily as the same in terms of their appearance, ceremonial stools are usually larger in size and also appear quite sophisticated in terms of its sculptural design and decoration compared to those used for bathing and eating.

In his Religion and Art in Ashanti, Rattray recounted that of the thirty-one stools recorded, seven of them were reserved for the Asantehene and could not be used or owned by anyone else. The golden stool, for example, belongs to only the Asantehene. According to Sarpong, the silver stool, similarly, can only be owned by the Asantehenemaa (queenmother of the Asante), Mamponhene ${ }^{207}$ and Techimanhene ${ }^{208}$ who uses this stool on occasions. Seven

\footnotetext{
${ }^{203}$ Quoted in Alex Kyeremanteng, Panoply of Ghana, (London: Longman Green \& Co., 1964), 11.

${ }^{204}$ Sarpong, The Sacred Stool of the Akan, 15-16.

${ }^{205}$ Patton, "The Stool and Asante Chieftaincy," 74.

${ }^{206}$ Patton, "The Stool and Asante Chieftaincy," 74.

207 Mamponghene (paramount chief of Mampong traditional area) is a important chief within the Asanteman council. He is traditionally "the next in command" in the Asante kingdom. See Rattray, Ashanti Law and Constitution.
}

${ }^{208}$ Some accounts have argued that the Techimanhene (paramount chief of Techiman traditional area), in the ancient times, Bonohene (king of the Bono kingdom), was the first to have used the golden stool before it was captured by the Asante. For a detailed account of the history of the Techiman traditional state and the Bono kingdom, see Eva L. R. Meyerowitz, At the Court of an African King (London: Faber and Faber Limited, 1962); Meyerowitz, The Divine Kingship; D. M. Warren and Owusu Brempong, Techiman Traditional State, vol. 1, 3 (Accra: Institute of African Studies, 1979). 
others were for other sub-chiefs, four were for priests and shrines, one was for the linguist, and one was for the stool carriers. The remainder belonged to ordinary citizens. ${ }^{209}$ This categorization, indeed, shows the profound religious and spiritual significance of the stool to the Akan. As Rattray asserts, "In Ashanti a generation or so ago, every stool in use had its own particular significance and its own special name which denoted the sex, or social status, or clan of the owner." 210 Sarpong, following Rattray's categorization, gave the names of the various stools and explained that although there was no limitation regarding the possession and use of the stool, its uniqueness depended on the owner's sex, age and status in the society. ${ }^{211}$

The stool, among the Akan, is also an important chiefly symbol. It is not a mere chair or only sitting place of the ruling chief but also a link between him and the ancestors. Part of the enstoolment (coronation, installation) ceremony of a new chief requires that the candidate is put on the stool which he acquires upon his appointment and nomination as a chief. The stool is what he uses as his personal seat while he is alive. The ideological foundation of the stool's sacredness is shared by all Akan people. As has already been indicated (in chapter two), among the Asante, for example, the golden stool is not just the seat of government but also the central symbol of unity and wealth of the Asante. A stool symbolizes stable foundation, that which enables one to rest by sitting on it. Traditionally, to pull as stool from one's buttocks is to call for the person's downfall. A stool is believed to be the repository of the history of the kingdom. Through it, the custom, culture and religion of the people are preserved. The golden stool, indeed, is the soul of

\footnotetext{
${ }^{209}$ It must be noted, however, that, according to Patton, by the time Rattray collected his data in the late 1920s, these traditional restrictions regarding ownership of the stool were gradually being ignored by the Asante.

${ }^{210}$ R. S. Rattray, Religion and Art in Ashanti (Oxford: Clarendon Press, 1927), 271.

${ }^{211}$ Sarpong, The Sacred Stool of the Akan, 19.
} 
the Asante state. Sarpong makes a compelling ideological argument when he aptly describes it thus:

The heavenly origin of the Golden Stool is obviously a myth. ${ }^{212}$ But it is a myth with tremendous practical consequences. If the Soul of the nation is contained in the stool, then it must be more important than any one person or group of persons, even the King. It follows, also that the custodian of this repository of the nation's Soul is the most important person. ${ }^{213}$

In chapter two, it was indicated that as an important symbol of the state, the people are always ready to die in defense of the stool. This assertion gave it practical expression when in 1896, the Asante state, choosing between stool and their king, defended the former. It is said that instead of surrendering the stool the people allowed the deportation of their king, Agyemang Prempeh I, to the Seychelles Island. Both oral and written history has it that in 1900, Governor F.M. Hodgson's demand for the surrender of the golden stool to him so that he could sit on it (as representative of the Sovereign, Queen Victoria of Britain), ${ }^{214}$ was an enough justification to spark the Yaa Asantewaa war. ${ }^{215}$ The demand of the stool was seen as an insult against the ancestors of the state, hence the need to wage war in defense of ancestral heritage. For anthropologists like Sarpong, the Governor's speech was "a classic piece of anthropological nonsense. In three sentences, he committed six blunders, each of which merited the death

\footnotetext{
${ }^{212}$ Sarpong's assertion is objectively based on fact-supporting historical accounts. History has it that the golden stool was captured during the invasion of the Bono kingdom. To discredit the conquered bono kingdom and to also divinely legitimizes it, the myth was created to conceal its human identity.

${ }^{213}$ Sarpong, Ghana in Retrospect, 129.

${ }^{214}$ See Sarpong, Ghana in Retrospect, 129; Rattray, Ashanti Law and Constitution, 273-293; Parrinder, "Divine Kingship in West Africa," 112.

${ }^{215}$ Interestingly, this war was led by a woman. What makes it interesting is that in traditional custom, women never went to war. See A. Adu Boahen, Yaa Asantewaa and the Asante-British War of 1900-1, ed. Emmanuel Akyeampong (James Currey, 2003); Arhin Brempong, "The Role of Nana Yaa Asantewaa in the 1900 Asante War of Resistance," Le Griot VIII (2000): 97-110.
} 
penalty. ${ }^{, 216}$ Sarpong enumerated the official errors as 1) No one asks for the golden stool; 2) no foreigner should meddle himself in the affairs of the golden stool; 3) one does not ask for the golden stool in the name of another person; 4) a "red" (white) man should keep his hands off it; 5) you don't ask for the golden stool for a woman, whom it often taboos, and 6) it is never sat upon, even by the king of Asante. ${ }^{217}$

The second and the fourth errors merit the some explanation. The governor, ignorant of the customs of the people, mistook the stool to be an ordinary throne instead of seeing it as what the myth and the tradition of the people had made it to be, "the shrine of the Asante Nation."218 For Sarpong, just as the ordinary Asante, the sin of sitting upon the golden stool by a foreigner is as sacrilegious as a Bishop of the Middle Ages giving the liturgical vessels such as ciborium and communion plate in his cathedral to his barbarian conquerors to feed from them. ${ }^{219}$ The demand for the stool was the motivating factor for the war that was led by a woman. Although the Asante conceded defeat to the British, in theory, they won victory for their state. They won the victory of protecting their ancestral heritage and "they succeeded in preventing it from becoming one of the exhibits in the British Museum. ${ }^{, 20}$ They were able to faithfully protect the stool which is the basis of their existence as a people. As Kimble reports:

\footnotetext{
${ }^{216}$ Sarpong, Ghana in Retrospect, 129.

${ }^{217}$ To an unfamiliar observer or reader of the Asante custom, this assertion might seem contradictory. However, it must be said that unlike other stools within the Asante kingdom, the golden stool is the single most important stool which is believed to be the "soul" of the state. Hence, no chief is worthy enough to sit on it. As such, although the Asantehene is said to be the occupant of the golden stool, he does not, strictly speaking, sit upon "the actual golden stool"- the soul of the kingdom. The golden stool is used only on special occasions such as enstoolment of a new king. Even that, as part of the rituals commemorating his enstoolment, the buttocks of the king is only placed on the stool thrice; and he does not fully sit in it.

${ }^{218}$ Sarpong, Ghana in Retrospect, 130.

${ }^{219}$ Sarpong, Ghana in Retrospect, 130.

${ }^{220}$ Sarpong, Ghana in Retrospect, 130. This assertion has, however been disputed. Historians do not agree on the authenticity of this claim. According to some other sources, the golden stool was captured by the British. The
} 
It was not until after the shock of this conflict that a new Governor, Nathan, was able to acknowledge the difficulties created by past policy, and recognized the existence, especially in Ashanti, of 'A complicated system of administration, hallowed by antiquity and historic precedents, which our ignorance and policy have alike tended to break down, and a deep-rooted superstition which we are unable to understand and from which our presence in the country has detached a portion of the people.",221

Thus, the said war indeed taught the colonial administration some important lessons about the indigenous tradition of the people.

The third most grievous sin of Governor Hodgson involves the belief that one does not ask for the golden stool in the name of another person. The uniqueness of the chiefly stool, in most cases, is limited to the members of the tribe alone. No other person can arrogate to himself the power over that particular stool. In some cases, the design and the name of the stool cannot be imitated. According to one historical tradition, during the reign of Osei Bonsu as Asantehene, the king of Gyaman (now in the land of Cote d'Iviore) was alleged to have made for himself a replica of the golden stool. Upon hearing this, the Asantehene sent his army to capture the said king. It is said that as a punishment for making for himself a golden stool, the king was killed and the stool was sent back to Kumasi, the Asante capital, where it was melted down and cast into two effigies of the Ivorian king which is hung on both sides of the golden stool. ${ }^{222}$

The fifth most serious sin about the stool is that you cannot ask it for a woman - a woman sitting on the chief's stool is abhorrent to the stool and tabooed. An important taboo related to the stool of the Akan is that of menstrual taboo. It is a great abususem "woeful things or expressions"223

current golden stool, it is believed, is not the original one captured during the Bono war or the one alleged to have been commanded by Okomfo Anokye.

${ }^{221}$ Kimble, A Political History of Ghana, 132. See also Confidential Dispatch of 19 Mar. 1901, from Nathan to Chamberlain; CO/96/378.

${ }^{222}$ Sarpong, Ghana in Retrospect, 130.

${ }^{223}$ See Kofi Agyekum, “Ntam 'Reminiscential Oath' Taboo in Akan,” Language in Society, 33, (3), (Jun., 2004), 318. 
for the king's stool to be sat upon by a woman. ${ }^{224}$ The expression onks ahenfie (she does not go to the palace) and snko nkonnwafie so (she does not go to the stool house) are very significant in our understanding of this concept. All measures are put in place to avoid any direct contact by menstruating women with the stool since menstrual blood is considered toxic and polluting. ${ }^{225}$. Agyekum explains that "[A]mong the Akan, menstruation is considered to be one of the most revolting, dreadful, polluting, and messy scatological substances, and the less said about it the better; that is why direct reference to it should be avoided as much as possible. This aspect of the negative model emphasizes men's purity and male superiority in male-dominated societies like the Akan. ${ }^{226}$

Traditionally, women are given the right to free movement including frequenting the chief's palace. However, because menstruating women are considered as unclean due to the believe in polluting nature of the menstrual blood, such right to free movement is curtailed or restricted especially from sacred places such as the palace and the stool house/room. According to Busia, ancient tradition permitted women to be chiefs. However, due to the menstruation taboo, they usually had to delegate men to become chiefs. This was necessary in order to avoid contaminating the performance of sacred duties and rituals with menstrual blood. ${ }^{227}$ Because the chief is the wealth and life-animating principle of his people, his sacred nature cannot be allowed to be contaminated by contact with the menstrual blood hence the prohibition of menstruating women from going to the palace.

\footnotetext{
${ }^{224}$ Indeed the target of this prohibition is menstruating women, but to avoid any accidental contact through forgetfully or any other compelling excuses, this is usually extended to all women.

${ }^{225}$ See Kofi Agyekum, "Menstruation as a Verbal Taboo among the Akan of Ghana," Journal of Anthropological Research, 58 (3), (Autumn, 2002), 374.

${ }^{226}$ Agyekum, "Menstruation as a Verbal Taboo," 374.

${ }^{227}$ Busia, The Position of the Akan Chief, 20.
} 
In most cases, certain important judgments or decisions are adjourned because a key witness "does not go to the palace" until such a time that the woman's menses are over. ${ }^{228}$ I must say that I do not entirely share this view. This view seems to reflect dominant patriarchic view in the society. An alternative interpretation might be the fear of the superior potency of menstrual blood which has the capacity of draining the spiritual potency of the stool. The superior potency of menstrual blood renders the stool's power less effective. Traditionally, the belief is that superior powers draw their powers from less powerful ones.

Upon the death of the chief, he is placed on the stool and bathed before his burial. The stool is then blackened and kept at the stool room, the shrine of his ancestral spirit. Each lineage has a chapel of blackened stools which is the shrine of its ancestors.

\subsection{The Nkonwafieso (Stool Room) as a Sacred Space}

Traditionally, each chief during his life time uses more than one stool. As was indicated earlier, each stool has its own purpose. At the death of the chief, the stool he mostly used is selected to go through the ritual of blackening it. The exact stool chosen for blackening has been a subject of debate. For some it is the stool that chief sat on to eat; for others it is the one used when the chief bathed. ${ }^{229}$ Still for others, it is the stool which the corpse of the departed chef was bathed before it was laid in state for the final public payment of homage that precedes burial. Whichever stool was the rightful one, the belief was that the stool that really has a direct connection with the soul of the chief was usually selected for the ritual of blackening. ${ }^{230}$

\footnotetext{
${ }^{228}$ Agyekum, "Menstruation as a Verbal Taboo," 377.

${ }^{229}$ Traditionally chiefs and most elderly people usually sat on chairs when taking their bath.

${ }^{230}$ Sarpong, The Sacred Stool of the Akan, 36.
} 
Traditionally each of the blackened stools are kept in the temple of the stools, referred to as nkonwafieso (stool-house). The chief's palace is architecturally designed such that the nkonwafieso is usually situated close to the chief's room. Although Sarpong explains that the reason for this closeness is because, as custodian of the stools, the chief must give the stools something to eat when he himself is eating, a close study of the tradition also indicates that, among other things, the chief must also be as close to this ancestral abode as possible. ${ }^{231}$ This is necessary for close communication with the ancestors and also for safe keeping of the stoolhouse since gold nuggets and other precious objects of honor are kept in the stool-house. The nkowafieso is usually kept from the public and from people who have no specific role to perform there. To evoke a great sense of awe, the stool-room is always dark and gloomy even during the daytime. The room is windowless as it is purposefully designed to ensure absolute safety of the sacred relics since they cannot be easily identified or accessed. ${ }^{232}$

At the stool house each is arraigned in order of succession, or according to some versions, in order of honor and dignity. Owing to their sacred nature, the blackened stools are kept from touching the floor. They are put on a specially made bed or a dais with blanket and other beddings wrapped around them. The stool-house, traditionally, is not only the temple of the stools, but it is also the repository of sacred ancestral heritage. "The stool-house," according to Sarpong, "then becomes the substitute for the mausoleum, where, but for the taboo, the cult to the ancestors would take place. ${ }^{233}$

\footnotetext{
${ }^{231}$ Sarpong, The Sacred Stool of the Akan, 48.

${ }^{232}$ Sarpong, The Sacred Stool of the Akan, 49.

${ }^{233}$ Sarpong, The Sacred Stool of the Akan, 51.
} 
As has been emphasized throughout this discussion, among the Akan, the stool is an important chiefly symbol not because it is a stool but because it is sacred. Its sacred nature demands that it be kept or cut off from the profane objects in the royal territory. Dadosky, for example, explaining Eliade's concept of experiencing the sacred, wrote that: "When an object becomes a hierophany, it is separated from, cut off from the rest of the "profane" world and becomes a locus of valorization. ${ }^{234}$ The stool as the abode of the ancestors has assumed a transcendent nature -from mere royal furniture to the abode of the ancestors. It is no longer a mere chair in the sacred sense. The concept of the sacred space for religious people must not be taken literally, for as Eliade says it is "not a matter of theoretical speculation, but of a primary religious experience that precedes all reflection on the world." Indigenous Akan experience has taught the people that the sacralized nature of the chieftaincy institution demands that places associated with it must be clean of all spiritual pollutant. Traditionally, because of its sacred nature, palaces and houses reserved for the chief are architecturally designed or built in such a fashion as to avoid any ritually unclean contact. Of course, such a segregation makes sense in the light of Eliade's observation that "[T]he sacred is always dangerous to anyone who comes into contact with it unprepared, without having gone through the 'gestures of approach' that every religious act demands. ${ }^{235}$ To avoid any contact with menstruating women, who are considered ritually unclean, for instance, specially designed places are built for them to separate them from the chief's palace, hence the Akan designation ттаати (mmaа, women, mu inside, thus places for women).

\footnotetext{
${ }^{234}$ Dadosky, The Structure of Religious Knowing, 68.

${ }^{235}$ Eliade, Patterns in Comparative Religion, 371.
} 
Traditionally, some have asserted that such segregation might (or rather is) not seem offensive to women. Women who held leadership positions in the chief's court that demanded that they go to the stool house, during their menses, were barred from doing so. As was seen earlier, the Akan idiom, onks nkonnwafie so (she does not go to the stool house) was used in apparent reference to the sacredness of the stool house. Queenmothers whose position in the society requires that they perform special function at the stool-house but reach the stage of "not going to the stool house," always have their rituals performed by proxy. Quoting Nana Afia Abrafi Kots, the queenmother of Techiman traditional area, Brempong wrote:

I am a woman but I never went to the stool room to make sacrifices or poured libation to the ancestors and the deities. Now, I can go to the stool room anytime to perform my ritual duties because I am now old. In my youthful days during ceremonial occasions, I had to order one of the elderly women to perform my duties for me during my period. ${ }^{236}$

This account, indeed, shows the understanding of women whose plight in the chief's house, in the context of modern understanding of equality, will be considered as segregation. However, the tradition regarding the sacrality of the stool house goes beyond the modern concept of equality to encompass strict adherence to the rules regarding the role of the stool. That the claims of the stool are more important than the claims of human equality, presents a lot of challenges which the study research seeks to unravel.

At the stool house the chief is the one responsible for the whispering of the incantation over the sacrifice to the ancestors. ${ }^{237}$ Through the rituals performed at the stool house, the departed chiefs are said to be given new life and the living chief is also given a renewed strength and protection to execute his responsibilities in the society.

\footnotetext{
${ }^{236}$ Brempong, "Chieftaincy and Traditional Taboo," 224.

${ }^{237}$ Apter, Ghana in Transition, p.106.
} 


\subsection{The Role of the Chief}

In their preface to Chieftaincy in Ghana, Culture Governance and Development, the editors observed the changing role of the chief in contemporary era. They observed that the Ghanaian chieftaincy institution has, throughout the ages, exhibited an extraordinary resilience. According to these editors, in the olden days the chief combined executive, legislative, judicial, military, economic and religious roles, among others. They observed that an important role of the chief in those days was to mobilize his subjects to war. The aim, among others, was meant to defend, protect, conquer and expand his territory. This indeed earned most of the chiefs such titles as Osagyefo, Bediako ("one came to engage in war"), Osahene (warrior's leader), Katakyie (the strong one) Okofo (the warrior), Agyemang (savior of the nation), Okofrobo (the one who climbs the rock to fight), Akompanin (mighty in warfare), etc. ${ }^{238}$ In contemporary times, the chief does not go to war but still has to fight a major enemy. As Odotei and Awedoba put it:

[T] he enemy is now poverty, hunger, disease, squalor, illiteracy, crime, injustice, environmental degradation, depletion of resources, greed, covetousness, ignorance and conflicts. These are challenges of the new millennium. The pomp and pageantry associated the institution mask the onerous responsibility and challenges that confront the modern chief. Chiefs are under pressure to achieve good governance in their traditional area within the parameters of the on-going debate that seeks ways of integrating tradition with modernity. ${ }^{239}$

To achieve this, the chief has to subject himself to the demands and tenets of contemporary global society, religious pluralism and international human rights regimes. The modern chief is expected to achieve some amount of growth and development within the context of contemporary human rights and legal regime. While doing so, he is also expected to preserve the sacred distinctiveness of his office which is part of what tradition has conferred on him. Indeed,

\footnotetext{
${ }^{238}$ See Kofi Agyekum, "The Sociolinguistic of Akan Personal Names," Nordic Journal of African Studies 15, no. 2 (2006): 206-235.

${ }^{239}$ Irene K. Odotei and Albert K. Awedoba, Chieftaincy in Ghana: Culture, Governance and Development (SubSaharan Publishers, 2006), 11.
} 
modernity has not only presented the chieftaincy institution with this new set of socio-economic challenges, but has also challenged the very person of the chief and the office which he (the chief) occupies. I agree with scholars who classify the contemporary functions of the chief under three broad categories ${ }^{240}$ : judicial, administrative and political. However, in the context of this study, only the judicial and religio-spiritual function of the chief will be given much attention.

Under the current (fourth republic) democratic dispensation, the role of the chief, especially his judicial function, has not been wholly taken over by the law courts although it is restricted only to the adjudication in "causes or matters related to affecting the chieftaincy." The 1992 Constitution and other statutes such as Act 459 and Act 759 imposed certain adjudicatory responsibilities on the chiefs. Act 759 , s 30 , for example, succinctly stipulates this responsibilities. The chief is mandated to institute the appropriate customary sanction, which in some cases becomes a source of conflict and dispute in the society. This will be dealt with in subsequent discussions.

It has already been observed that the day-to-day administration of the Akan traditional society is in the hands of the chief and his elders. The chief is the custodian and administrator of stool land properties. ${ }^{241}$ The administrative functions of the chief are guaranteed both by tradition and the country's Constitution. Similarly, the legislative function of the Akan chief cannot be overemphasized. He, in council with his elders, and with the guidance from the ancestors, enacts laws necessary for the governance of the tribal community. Closely related to the legislative role of the Akan chief are his judiciary functions. As a representative of the ancestors, the chief

\footnotetext{
${ }^{240}$ See for example, Brobbey, The Laws of Chieftaincy in Ghana, 35-8.

${ }^{241}$ Brobbey, The Laws of Chieftaincy in Ghana, 37.
} 
becomes the link between the living and the departed ancestors. He is a father, a parent figure of the tribal people, the living, because he has now become the de jure ancestor. ${ }^{242}$

It must be said that the limitation of the judicial powers of the chief did not succeed in barring his office from settling civil disputes in their area. Although today the judicial function of the chief has been taken over by the law courts and other human rights institutions, the chief still wields considerable judicial influence in his traditional area. Civil cases, especially disputes related to afissm, (literally, matters of the home) are usually referred to the chief's court for peaceful settlement. Albeit the citizens' awareness of their rights and the availability of the law courts, most cases are still sent to the chief's court for settlement. The belief is that, as the father and spiritual leader of the community and the people, coupled with his easily available presence, he is (or rather will be) well respected and his views will be well taken by his subjects. Disputing parties mostly resort to the law courts only when it is difficult to establish a truce.

The chief's role as the parent of the tribal people compels him to judge his people with fairness and equity to ensure peace and harmony in the society. That the chief's title, Nana, has both sacred and "the essential parental function of the chief," is evident in Abraham Akrong's report of the chief. According to him, by virtue of his enstoolment, the chief acquires a parental role as the representative of the ancestors. The parental role, he said, is inseparable from the social persona of the chief "because the process of transformation that makes the chief a sacred persona simultaneously makes him a representative of the ancestors."243

As a tribal judge of the people, he is to judge his people based on moral principles laid down by the ancestors who are the prime owners and judges of the society. The interpretation of

\footnotetext{
${ }^{242}$ Akrong, "Religion and Traditional Leadership in Ghana," 199.

${ }^{243}$ Akrong, "Religion and Traditional Leadership in Ghana," 199.
} 
the laws of the land that govern the social, economic, political and the religious development of the land are mainly in the hands of the chief and his elders. Disputes and unrest in the community are settled in a formal proceeding that allow each of the disputants to state and bring their case.

\subsubsection{Spiritual Function}

Throughout this study the spiritual nature of the chief has been emphasized. It has been established that the chieftaincy institution itself is a religious institution and spiritual duty. ${ }^{244}$ The chief, it has been shown, is the intermediary between the living and the dead. He is the one who occupies the stool of his ancestors. As Akrong observes, the blood relations that exist between the chief and the departed ancestors qualifies him to be the rightful person to intercede for the people. The relation also qualifies him to represent the people at the court of the ancestors as the priest of the people who can solicit the blessing of the ancestors. ${ }^{245}$ The filial bond and the direct blood relation between the chief and the royal ancestors gives the chief an exclusive privilege and advantage over all other spiritual functionaries of the land; to easily solicit the blessing and intercession for his people.

In most cases, with the aid of the traditional priest(s), the chief seeks the spiritual welfare of the community on daily basis. As a social and spiritual father of the land, the chief is responsible for the religious affairs of his people. He is the supreme religious leader of the community. Among the Bono of Techiman, on whom Warren Dennis undertook a comprehensive ethnographic study, "A new chief must present himself to and be approved by the main deity of Techiman township (Taa Mensah), just as any newly manifested deity must be

\footnotetext{
${ }^{244}$ For further details, see Brempong, "Chieftaincy and Traditional Taboos," 221.

${ }^{245}$ Akrong, "Religion and Traditional Leadership in Ghana," 201.
} 
approved by the paramount chief and his traditional council before it has permission to function freely." ${ }^{246}$ From this account, one sees an interdependency of the two spiritual leaders of the community. That is, while every traditional spiritual operation within the area must be given the kingly blessing of the chief, even before one is installed as a chief and subsequently have this power, he must seek the approval of the chief priest. As a religious leader of his community, his person and office are central in religious ceremonies of his people.

As a father for all members of his community, he is the one in charge of the invocation of customary and religious sanctions on his offending "children" of the community. It is for this reason that he must himself be morally upright. As Akrong reports, "[T]he status of the chief as a sacred personality or a de jure ancestor implies that anytime his actions contradict the norms and values that regulate his office he ipso facto ceases to be a chief and must be destooled."247 Thus the ultimate sanction given to the chief for his disregard of the constant advice of these enlightened ones, Nananom Mpanyinfor, is destoolement. ${ }^{248}$ It is for this reason that destoolment charges mostly center on issues of either flouting the taboos of the ancestors or the immorality of the chief.

\subsection{Destoolement of Akan Chief}

Destoolment simply refers to the official removal of the chief from the symbol of his sacred office, the stool. The discussion so far has provided enough bases to assume that the Akan chief should do no wrong and is over and must be above his people. Earlier in chapter three, it was observed that the council of elders were usually responsible for any misbehavior of the

\footnotetext{
${ }^{246}$ Warren M. Dennis, “Bono Royal Regalia,” African Arts 8, no. 2 (1975): 16-21.

${ }^{247}$ Akrong, "Religion and Traditional Leadership in Ghana," 198.

${ }^{248}$ Kimble, A Political History of Ghana, 126.
} 
chief. Quoting Yankah, it was again indicated that the linguist, for example, took the blame for every miscommunication or 'bad' word that came from the chief. This notwithstanding, the Akan constitution and law made provision for the destoolment of the chief for any private or public misbehavior. Where there were enough evidence and reason to assume so, "such pretensions of infallibility of the chief are discarded."249 Basing his argument of the Constitution of the Akan, Danquah has also observed that "[T]he founders of the Akan State Constitution in their wisdom instituted a mode of procedure whereby an unwanted and oppressive Chief, an insufficient or incapable Chief, an unmoral or easy-going Chief, could be deprived of his position permanently at any time the governed felt that there were good reasons for deposing and replacing him by a better man.",250

Among the significant reasons or charges that can lead to the destoolment of a chief, Sarpong gave a good summary thus:

A destooled chief is the last person whose memory anybody wants to keep fresh. He must have broken a taboo or committed a serious crime to merit his degradation. He may have committed adultery with his servant's wives; he may have bought and sold slaves who were considered as heirloom to the stool; he may have used the oath unreasonably; he may have cursed people. All these crimes can deprive a chief of his regal powers. Once this happens, he becomes, in the eyes of the people, more insignificant that a commoner who has no right whatever to be a chief. ${ }^{251}$

Under such occasions, formal allegations were leveled against the chief and he is given enough time to publicly respond to them.

\footnotetext{
${ }^{249}$ A. Kodzo Paaku Kludze, Chieftaincy in Ghana, (Lanham: Austin \& Winfield Publishers, 2000), 280.

${ }^{250}$ J. B. Danquah, The Akim Abuakwa Handbook (London: Foster Groom \& Co.,, 1928), 68.

${ }^{251}$ Sarpong, The Sacred Stool of the Akan, 39.
} 


\subsection{Conclusion}

The chief, among the Akan, is a sanctified figure who is the nerve center of the tribe. This chapter has revealed that the position of the Akan chief is determined by sacred ideological foundations. The political office of the chief is also, indeed, a religious one with a lot of sacred metaphors. The sacrality of the chief, has, however, over the years, been the source of conflict with occasional violent consequences. The contemporary Akan chieftaincy institution has now been confronted with, and must respond to, a host of realistic challenges regarding the sacred metaphors of the chief. The next chapter (chapter five) deals with some of these challenges. 


\section{CHAPTER V: CHIEFTAINCY AND THE IMPACT OF COLONIALISM AND}

\section{CHRISTIANITY}

I have for several years past been coming more and more to be of the opinion that 'Paramount Chiefs' are forfeiting much of their old authority over Sub-Chiefs and their people, because they are themselves losing sight of what their real position was under the old Constitution, and are endeavouring to exercise their authority in such a manner that it may, sooner or later, cause them to lose what still remains to them of it (R.S Rattray).

\subsection{Introduction}

At the end of his pristine work on the Asante Law and Constitution, obviously one of the most classic literatures on Akan legal and customary laws, R.S Rattray predicted the diminishing power and possibly the disintegration of the Akan chieftaincy institution. Rattray, through a closer observation and examination of the custom and practices associated with the chieftaincy institution came to the conclusion that the decline of chiefly authority of the Akan, with all its sacred metaphors, would come about through:

(1) The decline of the old religious beliefs and the preaching (without very much thought or care of results in many cases) of the doctrines of Christianity.

(2) The non-observance and non-enforcement by subjects and 'Paramount Chiefs', respectively, of the rightful obligations enjoined by Akan customary law, more particularly in relation to the question of land tenure and taxation.

(3) The attempts being made to centralize the government of a State at the expense of many lesser loyalties, and the fact that Paramount Stools, while of the one hand neglecting to enforce legitimate obligations due to them on their subjects, in other spheres claim greater powers and authority than those conferred upon them by the original Constitution. ${ }^{252}$

Developing further on these three compelling reasons for the demise of the chieftaincy institution, this chapter addresses the clash between traditionalism and modernism and the impact of such a clash. In this and the chapter that immediately follows, the discussion will be guided by the question: How have the people of Akan traditional societies, over the years, reacted to the sacred position of the Akan chief?

${ }^{252}$ R. S. Rattray, Ashanti Proverb: The Primitive Ethics of a Savage People (London: Oxford University Press, 1916), 408-9. 
I begin by taking a historical survey of the forces of change responsible for the struggling state nature the chieftaincy institution from colonial era up to the present time.

\subsection{Akan Chieftaincy and the Colonial Administration}

Earlier in chapter one, it was argued that the encounter with colonialism has, over the years, been seen as a curse due to its negative impact on the indigenous cultures, especially the chieftaincy institution. This notwithstanding, it must be said that the legal and official recognition of the chieftaincy institution as an essential part of the political system of the country dates back to the pre-independence era. For some scholars, the arrival of the colonialist and the subsequent usurping of the political system of the country did not significantly change the essence of the chieftaincy institution and the sacred position of the chief..$^{253}$

For such scholars, the argument goes, the policy of the colonialists, (especially during the era of Lord Lugard who attempted to make the indigenous political leaders agents of the colonialists), was to make the chieftaincy institution an essential part of its colonial administration. This school of thought argues that the indigenous political institutions, despite occasional confrontations with the colonial government, were given the freedom to operate within their own limits. Colonial interventions in the activities of the chief, they claim, were mainly for political expediency rather than anything else. As such, powerful and influential states were less likely to receive resistance and intervention from the colonial administrators than less powerful ones. ${ }^{254}$ The said decision was for a more politically proactive motive. The belief was that any unwarranted intervention carried out by colonial administrators risk the possibility of

\footnotetext{
${ }^{253}$ S. A. Brobbey, The Law of Chieftaincy in Ghana: Incorporating Customary Arbitration, Contempt of Court, Judicial Review (Accra: Advanced Legal Publications, 2008), 3.

${ }^{254}$ Richard Rathbone, Nkrumah \& Chiefs: Politics Of Chieftaincy In Ghana 1951-1960, First. (Athens: Ohio University Press, 2000), 13.
} 
undermining the authority and autonomy of the local leaders and also incurring the displeasure of the vast number of subjects the chief controls.

Chieftaincy institution, thus, was seen as an attractive instrument of not only mobilizing the indigenous people of Gold Coast, but also governing them. Such efforts, it has already been indicated in chapter one, led to the dual system of authority: the central government which was patterned under the Westminster style of government and the local government (to be distinguished from contemporary local system of government), which was founded on the indigenous traditional system of government, also called the Native Administration. ${ }^{255}$ The attempts to modernize the chieftaincy institution led to the introduction of several reform measures such as the Native Courts systems which were presided over by the chief and his officers - council of elders. Notwithstanding the good intentions of the colonial government, writers like Rathbone point out that "a somewhat ramshackle structure of municipal councils, overseen by usually confused colonial officials," 256 was created. Most of the colonial administrators knew little or nothing about indigenous political and social systems of the time. In their attempt to Europeanize the indigenous society, many of these colonial officers despise and treated the indigenous leaders, beliefs, norms, customs, cultures and practices with disrespect and contempt. This and similar other activities of the colonial contact undercut the office and person of the chief. In this section, I have sought to take a look at some of these activities.

The first most important challenge colonial contact posed to indigenous political structures was the disintegration of local cultures and political system. At the time of the colonial contact, most of the indigenous societies were at the peak of their political influence. Among the

\footnotetext{
${ }^{255}$ Brobbey, The Law of Chieftaincy in Ghana, 3; Rathbone, Nkrumah \& Chiefs, 11.

${ }^{256}$ Rathbone, Nkrumah \& Chiefs, 11; Inez Sutton, "Law, Chieftaincy and Conflict Colonial Ghana: The Ada Case," African Affairs 83, no. 330 (1984): 41-62.
} 
Akan, the Asante kingdom, for instance, was largely an important indigenous political unit of government which "was powerful enough to build up anything approaching a nation out of a large number of different tribes. ${ }^{257}$ However, the fame, the name and the fate of the kingdom were all greatly affected due to the contact with the colonialists. According to Kimble, the British, for example, soon recognized the threat the Asante kingdom posed to their (British) interest, especially in matter of the latter's extension of political influence beyond the Asante kingdom. As a result the Asantehene was removed. The encounter between the Asante and the British has been summarized by Thomas J. Lewin, when he noted that the Europeans: encroached more and more on Asante's autonomy. During the late nineteenth century, European, notably British, expansionism and imperialism deeply affected Asante political culture....The diffusion of British and other European agents as officials, soldiers, entrepreneurs, and missionaries and relentless spread of their politics, commerce, and values served as catalysts for socioeconomic changes in Asante body politic. As the scope and intensity of European activity and involvement increased in the closing decades of the century, Asante contended with the first sustained threats to their nation's independence and political sovereignty. ${ }^{258}$

Colonial administration took over the power and the privilege that had hitherto been the preserves of the chief. With the coming of the Europeans, power structures and focus were shifted from the office and person of the chief to the presence of the District Commissioner. ${ }^{259}$

A second challenge posed by colonialism is felt within the context of law and order. In matters of law and order, colonialism dispossessed the chief of any real powers as moral enforcer of the land. Earlier in chapter three, it was indicated that the laws and customs of the land are believed to have been given by the spiritual forces of the society. The chief, representing these spiritual forces, especially the ancestors, has the duty to protect and promote these laws. The

${ }^{257}$ David Kimble, A Political History of Ghana: The Rise of Gold Coast Nationalism 1850-1928 (Oxford: The Clarendon Press, 1963), 457.

${ }^{258}$ Thomas J. Lewin, Asante before the British: The Prempean Years, 1975-1900 (Lawrence: The Regent Press of Kansas, 1978), 40.

${ }^{259}$ Kimble, A Political History of Ghana, 471. 
contact with colonialism, however, cast a dent on this common belief in the society. A thirdparty-lawgiver was added to the already existing moral law givers of the indigenous society. Part of the colonial laws demanded that laws enacted by the indigenous religio-political leaders must be okayed with accent of approval from the colonial administrators. According to Kimble, with the imposition of foreign rule, even though the chief had the power to enact by-laws within his territory, those laws were to be in conformity with "a list of prescribed subjects, with the Governor's approval.",260

The introduction of the British judicial system, for example, greatly interfered with the traditional system of jurisprudence. The colonial administration oversaw matters related to major crimes such as "murder or arson but the vast majority of the crimes of violence and crimes against property were heard in chief's court or Native Courts as they came to be known." ${ }^{261}$ By this, the chief was deprived of the physical and moral sanctions he previously presided over. The new law provided a greater amount of security to the individual - both royals and commoners. Even when found guilty by the chief's court, the individual was sure of buying his head ${ }^{262}$ through the protection of the new judicial system in place. This, without a doubt, stripped the chief of some of his sources of income and influence in the society. For example, among the Ga of Accra:

It was said of King Tackie: 'He no longer has a Court in which to sell justice at Accra and so has no revenue. He has also no powers of punishment and so no means of making

\footnotetext{
${ }^{260}$ Kimble, A Political History of Ghana, 460.

${ }^{261}$ Rathbone, Nkrumah \& Chiefs, 11.

${ }^{262}$ In pre-colonial era, people condemned to death, under certain circumstances were given the opportunity to "buy their heads" (wats ne tiri), by paying heavy fine or other equally compelling heavy substitutes as determined or willed by the chief and his courts. For a detailed discussion on this concept and how it was applied in relation to the rights of the individual, see Seth Tweneboah, "Religious Human Rights in the Techiman Traditional Area of Modern Ghana" (MPhil Thesis, unpublished: University of Ghana, 2010), 47-48. See also R. S. Rattray, Ashanti Law and Constitution (Oxford: The Clarendon Press, 1929), 312.
} 
his nominal subjects obey him. He is an old man with the recollection of great former importance and of an influence extending over all the Ga-talking people and he naturally resents the new order of things and is not inclined to assist the Government that has brought it about. 263

This account indicates that the indigenous political leaders of the land did not only have a nostalgic return to the ancestral past but were also aggrieved of and resistant to the colonial intervention. Under such conditions, since the chief could not openly confront the colonial administration, citizens who fell afoul of the laws within the little powers that remained in his (the chief) hands, bore the brunt of his wrath. In most cases, the sanction meted out by the chief, within the context of the new society colonialism has created, turned to be regarded as too strict and a limitation of the rights of the chief's subjects. This, indeed, the focus of this study, will be discussed in details later in chapter seven.

A third difficulty the encounter with colonialism posed to chieftaincy institution was the destruction of the local customs. Because the chief presided over these customs (which are also the basis of the chief's authority), any act that sought to hinder them (customs) also, in turn, limited the power of the chief. Colonial intervention in matters related to customs, or what Rathbone refers to as "most culturally specific"264 issues were basically for political expediency. Rulers who were seen as powerful in their own right or were trusted by the colonizers were rarely distracted or had their activities intervened. Weaker and less co-operative chiefs were sure to always be frustrated by constant intervention of the colonizers. ${ }^{265}$ In most cases, even more co-operative chiefs were humiliated before their subjects. For example, in May 1913, during the visit of Sir Hugh Clifford, the chiefs of Sekondi, in their address to him registered their

\footnotetext{
${ }^{263}$ Quoted in Kimble, A Political History of Ghana, 466. For a full details of this see Confidential Dispatch of 10 Mar. 1901, from Nathan to Chamberlain; CO/96/378.

${ }^{264}$ Rathbone, Nkrumah \& Chiefs, 13.

${ }^{265}$ Rathbone, Nkrumah \& Chiefs, 13; Sutton, "Law, Chieftaincy and Conflict Colonial Ghana," 41.
} 
displeasure over the fact that they had to lower their cloth to their waist before the District Commissioner. ${ }^{266}$ The custom regarding this demand was taken seriously. Traditionally, this act of obeisance was (and still is) shown only to a superior authority. For a chief to be made to undergo this act was not only an embarrassing demand, but also a humiliating and coercive acknowledgement of his subordination to the colonial intruders.

In most cases, the colonial administrators viewed the local customs and practices with disdain and attempted to suppress it. Kimble, again, writes of the colonial administrator, Hodgson, reporting that: "Some of the dances in this colony are certainly so offensive to public decency that we cannot understand why they are not suppressed. The time has come for us to get rid of many of the old institutions which come directly into conflict with modern ideas of civilization... A list should be made of all the customs and institutions which should be abolished.",267

A fourth challenge was that the superimposition of external authority weakened the power of the chief and the sanctions at his disposal. Taken together, the forceful imposition of external forces ${ }^{268}$ could not bring the chieftaincy institution to its knees. What rather resulted from it was tension and acrimony between the chief and his elders, on the one hand, and their subjects and the colonial government, on the other. The introduction of western laws of governance, for example, opened the citizens to a lot of legal avenues and options. The Native Courts, for instance, redefined, reinterpreted, and in some cases, reinvented the customary laws

\footnotetext{
${ }^{266}$ Sir Clifford, it must be said, is in the good records of the chiefs as he established good relations with the chief. $\mathrm{He}$, unlike previous governors, assured and encouraged the chiefs to approach him with their problems. According to Kimble, Clifford was said to have believed in the "'tribal system' as the natural machinery of administration." See Kimble, A Political History of Ghana, 469. See also J.E. Casely Hayford, The Truth about the West African Land Question (London, 1913), 415.

${ }^{267}$ The Gold Coast Express, 28 Sept. 1897. Quoted in Kimble, A Political History of Ghana, 133.

${ }^{268}$ Kimble, A Political History of Ghana, 130.
} 
of the people. Colonial laws and their influences gave the citizens so much power that the people eventually became only "nominal subjects" of the chief. ${ }^{269}$ Citizens openly challenged the basis of the chief's power with contempt. It is said that within a period of twenty-two (1904-1026), the Akan-speaking traditional areas alone recorded over 109 cases of destoolment. ${ }^{270}$ The Annual Report on Ashanti in 1905, for example, observed that:

The number of civil and criminal cases heard before the Courts in Ashanti in 1905, exclusive of the appeals from the decisions of native chiefs which came before the Chief Commissioner, was 3,174 against 2,361 in the previous year. These figures support the opinion expressed by the Chief Commissioner that the Ashantis appreciate the impartiality of the British Courts of Justice, and are now deposed to place more faith in their administrators, who, it will be remembered, are not only judicial but also executive officers. ${ }^{271}$

The colonial intervention undermined not only the judicial and executive role of the chief but also prevented the full performance of religious ceremonies needed for the smooth running of the society. It is also interesting to add that the adoption of the indigenous political system by the colonialists opened the way for the chief to be given occasional allowances. However, most of these allowances were woefully inadequate. In most cases uncompromising chiefs had their allowances stripped off. In "Religious Human Rights in Techiman Traditional Area of Modern Ghana," building on Meyerowitz's observation, I discussed how the presence of the colonial administration led to the breakdown of religious performance which resulted in the death of two important divisional chiefs in Techiman traditional area. I indicated that in the late 1940s, following the Omanhene's confrontation with, and refusal to render apology to the colonial District Commissioner, Hawkesworth, the former's allowance was suspended for over six months. This led to a major financial constraint on the Omanhene and his people. As there was

\footnotetext{
${ }^{269}$ Kimble, A Political History of Ghana, 466.

${ }^{270}$ Rathbone, Nkrumah \& Chiefs, 13.

${ }^{271}$ Ashanti, Colonial Annual Report on Ashanti in 1905, No 483. 3.
} 
no money to pay for the libations and other important rituals, the people believed that the society was visited with a host of ill-luck including the death of two divisional chiefs (Adontenhene and the new Krontihene). ${ }^{272}$

The insufficient allowances given to the chiefs also opened them to corrupt practices such as the selling of stool lands and other acts that did not befit their sacred status. Such acts were very serious offenses to both the citizens and the ancestors. It is noteworthy to mention that although there were always measures put in place to curb chiefly corruption, such practices were, in most cases, inevitable due to the financial constraint that most of them found themselves in under colonialism. For example, it is said that after the enstoolment of King Prempeh I, and following the civil unrest that brought him to power and the elaborate nature of the installation ceremony, his financial status became weak. He approached the British governor of the Gold Coast in 1888 for a personal loan of $£ 400$. This act was, obviously, vituperative - an offense against the good name of the golden stool and a disgrace to the ancestors. This is because the occupant of the golden stool cannot beg for money. Doing so is inconsistent with the wealth of gold he sits on. However, when this matter "became public in Kumase through the indiscretion of Inspector Lethbridge, the official entrusted with the handing the money over in private,"273 King Prempeh I shrewdly denied any knowledge of it. King Prempeh I might have been aware of the spiritual and the political dangers and implications of this action. The incident had the potential of bringing not only the occupant of the golden stool into disrepute but also the whole Asante nation.

\footnotetext{
${ }^{272}$ Tweneboah, "Religious Human Rights," 63-5.

${ }^{273}$ Emmanuel Akyeampong, "Christianity, Modernity and the Weight of Tradition in the Life of 'Asantehene' Agyeman Prempeh I, c. 1888-1931,” Africa: Journal of the International African Institute, 69, no. 2 (1999): 285.
} 
The impact of colonialism on the Ghanaian chieftaincy institution in general and the Akan in particular cannot be adequately covered in a single work of this nature. The colonial interference in preventing much of the inter-state warfare of conquest and expansion worked heavily against most chiefs and their states. The end of inter-state warfare which seemingly followed the colonial intervention meant a denial of an essential means, among others, of extending their control over weak and vulnerable smaller states. It was a prevention of "the main means of gaining new prestige, territory, and wealth, and of providing an outlet for the aggressive impulses of their young men."274

The intervention, however, was a great relief to the individual subject who was by then, in constant fear of attack, slave raiding and unprepared warfare. However, the few states that still remained under the authority of powerful states usually suffered the consequences of this colonial intervention. Raymond Bagulo Bening, has for example, discussed some of the concerns that most of the chiefs of the smaller states under the then Asante kingdom raised. Among others, Bening observed that most of the chiefs agitated their own independent states due to the fear of the tyranny of the Asantehene. ${ }^{275}$

\subsection{Chieftaincy and Plurality of Religion}

An important characteristic of indigenous African religious tradition is its tolerant nature and its ability to adapt to the changing dynamics of the religious landscape. The indigenous religious traditions of Africa are credited with adopting foreign religions for their apparent utility. Busia, writing about the religion of the Asante, for example, observed that:

\footnotetext{
${ }^{274}$ Kimble, A Political History of Ghana, 129.

${ }^{275}$ For a good discussion on this development, see Raymond Bagulo Bening, Ghana: Regional Boundaries and National Integration (Accra: Ghana Universities Press, 1999).
} 
Ashanti religion was very hospitable, and the Ashanti took over the beliefs, the gods and rites of conquered as well as those of the neighbouring tribes; from the Moslem north, they brought charms and amulets which were highly prized for the protection they were believed to give in battle. None of these borrowed faiths displaced the fundamental beliefs of the Ashanti. New gods and faiths were merely additions which were believed to give more power and protection against the spirits and forces of the world.",276

For other scholars of indigenous African religions, African's contact with foreign religions broadened the horizon of the society and opened newer challenges and possibilities to the people. ${ }^{277}$ Part of the problem was that the contact introduced newer forms of religious and philosophical ideas that challenged the hitherto dominant values of the society. In "Religious Human Rights in the Techiman Traditional Area of Modern Ghana," I, again argued that with the acceptance of "guest religions" into their midst, indigenous societies of African compromised all forms of practical and ideological monopoly which it had previously enjoyed. ${ }^{278}$ There was a silent agreement that these other religions which were welcomed, even if unconsciously, were free to operate. This (the co-existence of several religious traditions), to be sure, is the basis of religious pluralism.

Religious pluralism, today, has challenged the once taken-for-granted beliefs and practices of the indigenous society particularly with regard to the authority of the chief. For purposes of easy analysis, I have chosen to focus on only Christianity, which since the time it first arrived, has presented (and still is presenting) a greater challenge to the authority of the chief. Christianity, it is interesting to note, contributed greatly in diverse ways towards the development of African indigenous societies. It provided the earliest forms of western education

\footnotetext{
${ }^{276}$ K. A. Busia, "The Ashanti of the Gold Coast," in African Worlds: Studies in the Cosmological Ideas and Social Values of African Peoples, ed. Daryll Forde, Reprint. (Munster-Hamburg: International African Institute, 1999), 191.

${ }^{277}$ Robin Horton, “African Conversion," Africa: Journal of the International African Institute, XLI, no. 2 (April 1971): 85-108.

${ }^{278}$ Tweneboah, "Religious Human Rights," 34.
} 
whose beneficiaries led the struggle against political colonialism. As Kimble has rightly observed, most of the early educated Africans were mainly products of Mission schools. Their acceptance of the religious teaching of these schools served as a motivating occasion for embracing new Western ways of life, and a basis for some new forms of political ideologies. ${ }^{279}$ The churches, Kimble writes, "were usually ahead of the Government, and they provided some Africans leaders with a forum, and an unaccustomed freedom of expression, both in the pulpit and the press. ${ }^{, 280}$

Despite these good intentions, the Christian churches have been accused of undermining the religious and cultural practices of the very people they sought to "liberate." During the early years of missionary activities, the challenges were as swift and radical as they are today. The first most important challenge Christianity presented to the indigenous cultures of Africa, as in other areas, was the erosion of the authority of the chief. Bartholomew de Las Casas, advocating for the native people of Latin America in resisting any forceful supplanting of "foreign" governance and colonization, for example, has argued that:

Any reasonable person who knows anything of God, rights and of civil law can imagine for himself what the likely reaction would be of any people living peaceable within their own frontiers, unaware that they owe allegiance to anyone save their natural lords, were a stranger suddenly to issue a demand along the following lines: 'You shall henceforth obey a foreign king, whom you have never seen nor ever heard of and, if you do not, we will cut you to pieces'... ${ }^{281}$

The above situation was not different from that of indigenous people of Africa. As has already been discussed, prior to Christianity, the only "supreme leaders" of the land was the ancestors represented by the tribal chief. The introduction of the Christian doctrine of heavenly authority

\footnotetext{
${ }^{279}$ Kimble, A Political History of Ghana, 161.

${ }^{280}$ Kimble, A Political History of Ghana, 161-2.

${ }^{281}$ See Las Casa, Short, 53 quoted in Whitney Bauman, Theology, Creation, and Environmental Ethics: From Creatio Ex Nihilo to Terra Nullius (New York: Routledge, 2009), 62.
} 
challenged the sacrosanct power of the people of Africa and presented the greatest hindrance to the position of the chief and the customs of the area under his (the chief's) jurisdiction. It introduced the concept of individual responsibility, a doctrine which alienated the individual not only from the larger societal members and its rulers, but also from the members of the wider universe. Traditional Christian doctrine taught its believers that they were not citizens of the present world. In most of their devotions and services, they were encouraged to sing and remind themselves that:

This world is not my home, I'm just a passing through, My treasures are laid up somewhere beyond the blue;

The angels beckon me from heaven's open door, And I can't feel at home in this world anymore.

As people whose home is somewhere up there in heaven, of what need is it to participate fully in the affairs of this transient world? This idea, indeed, was one of the greatest challenges that Christianity posed to indigenous cultures and the leaders of the society. As Busia has observed, Christianity right from its early stages sought to erode the Akan chieftaincy institution by attempting "to oust the chief as the religious head of his people; but the office of the chief is not, in the Ashanti conception, divisible into secular and sacred, or political and religious, so the conflict remains unresolved." 282 For example, in the 1905 Colonial Annual Report on Ashanti, the Chief Commissioner, F. C. Muller, clearly indicated that:

The tendency of Christian converts to alienate themselves from the communities to which they belong is very marked, and is naturally resented by the Chiefs, who claim their hereditary right, in which they are supported by the Government, to make the converts, in common with their fellow tribesmen, obey such laws and orders as are in accordance

${ }^{282}$ Busia, "The Ashanti of the Gold Coast," 208. 
with native custom, not being repugnant to natural justice, equity and good conscience. The problem requires and, hitherto, on the whole, has been treated with tact and forbearance by the various missionary societies. ${ }^{283}$

It is not clear how this issue was handled with dexterity and forbearance but ample instances abound to suggest that the sour relationship between the chief and the missionary coverts continued unabated for several decades. Disgruntled chiefs who could no longer tolerate this situation used various means and tactics to register their protest. For instance, in 1941, King Ofori Atta I, the king of Akyem Abuakwa traditional state, a very influential and well learned king, taking advantage of the invitation thrown to him to address the Synod of the Presbyterian Church of Ghana in his territory, registered his displeasure about the activities of missionary converts in his area. The king accused the Christians and their activities of undermining and polarizing the political and cultural unity of his territory. He proposed the need for a truce between the converts and members of his ancestral territory. This was later published as the Memorandum to the Presbyterian Church of the Gold Coast by the State Council of Akyem Abuakwa. ${ }^{284}$

The introduction of Christianity presented a new challenge unsurpassed hitherto. The new challenge was to the traditional concept of the sacrality of the land which led to the clearing of most of the traditional sites reserved for the ancestors. Ancestral groves are now used for industrial and commercial purposes. Owing to the challenge Christian doctrine presented especially to indigenous beliefs and practices, the individual Akan became no longer "communalistic" but highly "individualistic" with personal preferences that deserve recognition and respect. The individual was longer a religious Akan but only a biological one. Though the

${ }^{283}$ Ashanti, Colonial Annual Report (Great Britain: House of Commons, April 23, 1906).

${ }^{284}$ Jarle Simensen, "Christian Church, 'Native State' and African Culture the Presbyterian Mission in Akyem Abuakwa, Ghana" (Special Session on Missions, Modernization, Colonisation and Decolonisation. presented at the 19th International Congress of Historical Sciences, Oslo, August 6, 2000). 
individual still possesses the sacred Akan ancestral entrails, his or her personal liberty to freely choose or not to believe makes him or her free to decide whether to or not to adhere to the traditional practices.

With the introduction of Christianity, the hope had been that "the 'traditional' view of a dangerous world, inextricably associated with the kingship," or the chieftaincy institution would disappear. ${ }^{285}$ Christianity provided its believers with a host of ideological basis that sought to devalue indigenous beliefs and practices which the chief had hitherto presided over. Using Christianity as his case study, in "The Historical Roots of Ecologic Crisis," Lynn White, for example, identified the cause of what he termed as man's unnatural treatment of nature and the catastrophic consequences of such behavior. ${ }^{286}$ Christian doctrine has alienated man from the sacred relationship that existed between nature and man, such that nature became understood as meant to be subdued and dominated. "To a Christian a tree can be no more than a physical fact. The whole concept of the sacred grove is alien to Christianity and to the ethos of the West. For nearly 2 millennia Christian missionaries have been chopping down sacred groves, which are idolatrous because they assume spirit in nature. ${ }^{.287}$ Many of the practices were seen as demonic and "unchristian" and believers were encouraged to disassociate themselves from them. The belief in sacred ancestral groves, for example, was discouraged and such places were treated with contempt.

\footnotetext{
${ }^{285}$ Michelle Gilbert, "The Christian Executioner: Christianity and Chieftaincy as Rivals," Journal of Religion in Africa 25, no. Fasc. 4 (1995): 347-386.

${ }^{286}$ Lynn White, “The Historical Roots of Our Ecologic Crisis," Science 155, no. 3767 (March 10, 1967): 12031207.

${ }^{287}$ White, "The Historical Roots of Our Ecologic Crisis," 1206.
} 
In the context of Africa, Charles Anyinam summarizes the whole history thus:

The result of that confrontation has been the collapse of some cults and the decline of many others. During the colonial period, the concept of territorial cults came to be challenged and the breakdown of an ideation and organization complex which had sustained African societies for many centuries was initiated. More directly, the challenges came from the Christian churches which questioned the religious basis of the cult and from the colonial administration which became intermittently involved in sharp conflicts with the religious leadership. ${ }^{288}$

In most cases, efforts to till, dominate and subdue such ancestral territories were met with stiff oppositions from the traditionalists. In situations where the missionaries were no match to the chief and his people, colonial ordinances and powers were used to subdue them. For example, among the Fante, the Nananom Mpow of Obidan near Mankesim in the central region of Ghana was the most significant sacred grove of the area. The shrine of the grove was the spiritual center for the chief and the people of the area. It was the place where the chief and his people communicated with the sacred ancestors of the land; it was of a preeminent religious significance. ${ }^{289}$ It is on record that in 1951 attempts by the converts of Christianity to desecrate the land led to the clash between the traditional priests, the custodian of the Nananom Mpow, and the Christians. Following the seeming defeat of the Christians, the missionaries through the support of the colonial government, invaded the sacred grove, cleared it and erected their temple there. What was worrying about this was that the grove was not only a local shrine. With time, it grew to become the regional religious centre ${ }^{290}$ Fante history has it that the site of the Nananom Mpow was the royal mausoleum, the burial place where the great sacred founders of the Fante

\footnotetext{
${ }^{288}$ Charles Anyinam, "Ethnomedicine, Sacred Spaces, Ecosystem Preservation and Conservation in Africa," in Sacred Spaces and Public Quarrels: African Cultural and Economic Landscapes (Trenton and Asmara: Africa World Press, Inc., 1999), 142.

${ }^{289}$ Rebecca Shumway, "The Fante Shrine of Nananom Mpow and the Atlantic Slave Trade in Southern Ghana," Intemational Joumal of African Historical Studie 44, no. 1 (2011): 27-44.

${ }^{290}$ Shumway, "The Fante Shrine of Nananom Mpow and the Atlantic Slave Trade in Southern Ghana," 44.
} 
state, Oburumankoma, Odapagyan, and Oson, the holy ancestors of the Fante people, were buried. $^{291}$

Christianity undermined the emerging cultural and spiritual civilization of the people of Africa. The tendency to measure civilization and development in terms of economic growth has always been high and unavoidable. However, many are the schools of thought who are of the view that measuring a people's development in terms of their economic growth alone is not only erroneous but also deceptive. In measuring development, the people's historical context must be taken into consideration. As Walter Rodney argues:

All of the countries named as 'underdeveloped' in the world are exploited by others; and the underdevelopment with which the world is now pre-occupied is a product of capitalist, imperialist and colonialist exploitation. African and Asian societies were developing independently until they were taken over directly or indirectly by the capitalist powers. When that happened, exploitation increased and the export of surplus ensued, depriving the societies of the benefit of their natural resources and labour. That is an integral part of underdevelopment in the contemporary sense. ${ }^{292}$

An important component of the African traditional worldview about social relationship is what Kwame Gyekye refers to as "the ontological primacy of the community" life. ${ }^{293}$ Drawing on the views of scholars such as Kwesi Dickson, J. S. Mbiti, Ifeanyi Menkiti, and a host of others, Gyekye took this argument further to assert that:

[T] he community, that is, a cultural community, not only is a basis both for defining and articulating the values and goals shared by several individuals but alone constitutes the context, the social or cultural space, in which the actualization of the potentials of the individual can take place, providing her the opportunity to express her individuality, to acquire and develop her personality, and to fully become the kind of person she wants to be. $^{294}$

\footnotetext{
${ }^{291}$ Shumway, "The Fante Shrine of Nananom Mpow and the Atlantic Slave Trade in Southern Ghana," 28.

${ }^{292}$ Walter Rodney, How Europe Underdeveloped Africa, Revised. (Howard University Press, 1981), 14.

${ }^{293}$ Kwame Gyekye, Tradition and Modernity: Philosophical Reflections on the African Experience (Oxford: Oxford University Press, 1997), 37.

${ }^{294}$ Gyekye, Tradition and Modernity, 39.
} 
This assertion reveals the indispensability of the individual in the society as a "communal being" for the development of the society. However, with the coming into contact with other religious traditions, the African concept of the traditional emphasis on family life was affected. ${ }^{295}$ To be able to maintain their converts and to also make sure these converts did not revert to their native religion, the early Christian missionaries isolated their converts from the local people. The converts were quarantined in separate areas of the community. ${ }^{296}$ In Ghana, such places specially designated to the converts became known as skuul mu (skuul, school, mu, inside), broni kurom (broni, kurom, town), gyidie mu (community of the faithful), etc. Dwellers of such places were believed to be special people who must not have anything to do with their "idolatrous" and "heathen" neighbors lest they became contaminated. Among the people of Zambia, within such communities, Rotberg writes that:

All aspects of traditional marriage were prohibited by the missionaries: polygamy, bridewealth, and a host of associated practices were roundly condemned... All ... tried to eliminate beer brewing and drinking... Tribal dancing and singing, which generally offended missionaries and their wives, were prohibited...In all... the missions advocated austerity, and expected the Africans... to deport themselves in a manner befitting newly made Christians. ${ }^{297}$

These and other similar measures were put in place in order to make sure that their converts remained faithful to their newly acquired religion. However, the problems created by such actions were that converts turned to disassociate themselves from the social activities of the community. In many cases, there were occasional confrontations between the chief and the elders of the community, on one hand and the missionaries and the converts, on the other.

\footnotetext{
${ }^{295}$ It must be said that although religious pluralism in this study refers to all the religious traditions in the Akan traditional societies, for purposes of easy analysis, I have chosen to analyze the impact of only Christianity.

${ }^{296}$ Ryan, "Is it Possible to Construct a Unified History of Religion in West Africa?".

${ }^{297}$ Robert I. Rotberg, Christian Missionaries and the creation of Northern Rhodesia 1880-1924 (Princeton: Princeton University Press, 1965), 40-1.
} 
Because these converts saw themselves as the "called out ones," they saw no need to engage and participate fully in social and communal activities that were geared towards the development of the larger community. It must be remembered that those were the days (and even today) when the chief and his elders of the community mobilized their members for communal development. ${ }^{298}$ Citizens who disassociated themselves from such communal projects were seen as saboteurs and were made to face the full rigors of the traditional sanctions. However, because these converts did not see themselves as members of the community, clashes and conflicts (which were sometimes violent) were frequent.

Not only were the indigenous societies of Africa unjustly exploited with the introduction of Christianity, the indigenous practices of the people were looked down in disdain. "Images of barbarism, bloodshed, and slavery tended to dominate European thinking about Gold Coast society; and many honestly felt that the solution was to suppress all the savage and heathen customs. Then surely, it would be only a matter of time and suitable Ordinances before superstitions were dispelled, and replaced by more enlightened modes of conduct." ${ }^{, 299}$ It must be emphasized that although the Native Administration Ordinance of 1927 was meant to give the native states of the Gold Coast a substantial amount of autonomy, in cases where traditional beliefs and practices were seen as undercutting those of Christians, subtle measures were employed to suppress the former. Busia, for instance, writes that particularly in Asanteland, Christian converts refused to perform their duties as citizens of the indigenous state on grounds that as members of the called out ones, they could not engage in "fetish observances."

\footnotetext{
${ }^{298}$ It is quite important to add that this chiefly authority has been given legal recognition by the government of the Republic of Ghana. Per Article 63 (e) of the Chieftaincy Act 2008, Act 759, it is an offense to refuse to participate in communal labor organized by the chief, without any reasonable cause.

${ }^{299}$ David Kimble, A Political History of Ghana, 131.

${ }^{300}$ Busia, "The Ashanti of the Gold Coast," 207.
} 
Following this, according to Busia, in 1912, a committee consisting of the Governor of the Gold Coast, the Chief Commissioner, three other officials, representatives from the various missionaries operating on Asanteland - Wesleyan, Basel and Roman Catholic - made attempts to resolve the issue and came up with the ruling that: "No Christian shall be called upon to perform any fetish rites or service, but shall be bound to render customary service to his chief on ceremonial occasions when no element of fetish practice is involved. ${ }^{301}$

With the support of the colonial administration, Christianity gained the upper hand by undermining the authority of the chief in terms of disregarding the chief's ancestral culture, beliefs and practices of the land. As has been indicated, in cases where the local beliefs and practices of the people undercut the Christian doctrine, suitable ordinances were used to suppress them so as to allow Christianity the sole liberty to operate. As Kimble observed, among the costal natives of Gold Coast, "A similar parochial outlook was displaced by F.M. Hodgson in 1896, when he proudly reported that the Head Chief of Srah had formed 'a drum and fife band with English instruments,' and that there were several others in nearby towns: 'I am glad to see this disposition on the part of the natives to abandon their hideous performances on tom-tom and natives horns in favour of music of a more civilized character. It marks an advancement towards enlightenment." ${ }^{302}$

Similarly, Kimble reports that: "Toward the end of the century we find Hodgson writing approvingly that King Mate Kole had discarded native dress, 'by reason of his education and therefore more enlightened ideas', and supporting his application to wear a special uniform on

\footnotetext{
${ }^{301}$ Busia, "The Ashanti of the Gold Coast," 207.

${ }^{302}$ Kimble, A Political History of Ghana, 132. For full details of the report see Dispatch No. 386 of 29 Sept. 1896 , from Hodgson to Chamberlain; CO/96/277.
} 
occasions of state." ${ }^{303}$ Indeed, "European styles of dress were important as an outward and visible sign of inward and spiritual superiority." $" 304$ Thus, the adoption of Euro-Christian musical instrument was seen as a sign of human development and intellectual advancement brought by the introduction of western education without considering its effect on the indigenous political leaders.

\subsection{Conclusion}

This chapter has tried to explore the effects of the contact with European colonialism and Christianity on the indigenous political structures of Africa particularly on Akanland. The chapter has established that the contact was a big blow to the successful rise of the tribal states of Africa. The combined forces of the two - colonialism and Christianity - dispossessed these tribal states of all dynamism. The arrival of the colonialists and missionaries occurred at a time when most of the states were asserting their dominance and superiority. All these suddenly stopped with the coercive imposition of foreign powers, laws, religion, etc. These western imposed forces rather opened the indigenous societies to modernized ways of doing things and understanding reality which in turn affected (or rather challenged) the sacred basis of the authority of the chief. In the chapter that follows, I discuss the effects of modernity and globalization and how these affected the authority of the chief and the responses associated with these challenges.

\footnotetext{
${ }^{303}$ Kimble, A Political History of Ghana, 134.

${ }^{304}$ Kimble, A Political History of Ghana, 133.
} 


\section{CHAPTER VI: CHIEFTAINCY, MODERNIZATION AND GLOBALIZATION}

\subsection{Introduction}

The discussion in the previous chapter has given sufficient indication to conclude that the traditional sovereignty of indigenous African political structures was hijacked and replaced with an alien heart. ${ }^{305}$ The chapter established that colonialism and Christianity introduced western democratic values, independent judiciary system free from the sole influence of the chief as well as the fleet from religio-cultural excesses such as death penalty associated with flouting the customs of the land. However, these foreign values were uncritically adopted in a manner that undermined the authority of the chief. It was demonstrated that the presence of the colonial powers and Christianity, despite the good results that came with it, in sum, became "a burden and a curse. ${ }^{, 306}$ This chapter takes a look at some of the resulting challenges that came with these forces in terms of "the twin evils" modernity and globalization.

\subsection{Modernization and its Effects on the Power of the Akan Chief}

In this section I focus on the impact of modernity on the indigenous political structures with special emphasis on the Akan chieftaincy institution. To begin, I discuss some of the basic assumption regarding the modernization of the indigenous societies. Social and political analysts seeking solutions to African's and other society's socio-political and economic problems have rejected the Rostonian take-off theory ${ }^{307}$ and similar others, attributing the problem, inter alia, to

\footnotetext{
${ }^{305}$ According to Ali Mazrui, the original heart of African has been transplanted with an alien heart with the adoption of foreign cultures and religions. See Ali A. Mazrui, The African: A Triple Heritage (Boston \& Toronto: Little, Brown and Company, 1986).

${ }^{306}$ Davidson, The Black Man's Burden, 76.

307 The Rostonian take-off argued that development historically has taken place in five main stages. 1) traditional society 2) preconditions for take-off, 3) take-off, 4) drive to maturity, and 5) age of High mass consumption.
} 
the misappropriation of these foreign values. Early modernization theories, they claim, were too simplistic and overlooked the complexities of the problem. As Ronald Inglehart and Christian Welzel have argued, while socioeconomic development powerfully impact what people want and do, the cultural heritage of a society continues to wield influence and shape prevailing beliefs and motivations. Socio-cultural change, they argue, is not linear. ${ }^{308}$

There is yet another school of thought, for example, that believes that the political instability and civil unrest in the continent of Africa are as a result of misappropriation and misintergration of western civilization and indigenous forces. At least there is sufficient agreement among most scholars and observers about this assertion. The civil unrest, the argument continues, goes beyond political issues to cover ethno-tribal homogeneity. The former president of Ghana, Flt Lt Jerry John Rawlings, for example, has reechoed in his comments on the 2010/2011 Ivorian electoral crisis - which saw the exit of Laurent Gbagbo's ten year regime - the need for an overarching caution in managing the Africa's political crisis. According to expresident Rawlings, "the situation in Cote d'Ivoire was not a simple electoral dispute but a web of ethnic and political complexities that should be handled with tact and diplomacy rather than the open hints of forceful intervention." The ex-president's observation reaffirms Ali Mazrui's view about the woes associated with the concept of modernization in the context of Africa.

In his The African: A Triple Heritage, Ali Mazrui rejected the modernization theories that are not in consonance with the African soul. He observed that the crisis in the continent has been

\footnotetext{
Traditional societies, he said, can be helped to catch up with the highly advanced ones if they are able to lineally follow his five step precondition. W.W. Rostow, The Stages of Economic Growth: A Non-Communist Manifesto (Cambridge: Cambridge University Press, 1960).

308 Ronald Inglehart and Christian Welzel, Modernization, Cultural Change, and Democracy: The Human Development Sequence (New York: Cambridge University Press, 2005), 1.
} 
due to "the curse of cultural sabotage" pronounced by the ancestors. ${ }^{309}$ According to Mazrui, the ancestors of Africa, the landowners of the continent, are aggrieved and are unhappy in their graves. The sacrality of their land had been contaminated as a result of foreign or unAfrican influences. As such, all indications point to the fact that these ancestors seem to be "fighting back to avert the demise of Africanity." ${ }^{310}$ Mazrui agreed with the Nigerian novelists that until such an ancestral curse is reversed,

Warriors will fight scribes for the control of your institutions; wild bush will conquer your roads and pathways; your land will yield less and less while your offspring multiply; your houses will leak from the floods and your soil will crack from drought; your sons will refuse to pick up the hoe and prefer to wander in the wilds; you shall learn ways of cheating and you will poison the cola nuts you serve your friends. Yes things will fall apart. $^{311}$

This obviously is a very worrisome curse pronounced on the descendants of the ancestors, but the curse is not without a cause. The descendants have "sinned." For Mazrui, the decision to abandon ancestral heritage in place of western values is a grave unfaithfulness to the ancestors "an attempt to 'modernise' without consulting the cultural continuities," the challenge to start the process of 'dis-Africanising' Africa. ${ }^{312}$ Such attempt is a broken contract - to be faithful to the legacies of the ancestors whilst they, in turn, bless the land with peace and stability. Hence the ancestors are fighting their descendants.

It interesting to add that in such a fight, the sacred chief, the representative of the ancestors is on one hand while the political leaders of modern nation-state, the beneficiaries of the consequences of colonialism and disAfricanization process, are on the other side. The effect

\footnotetext{
${ }^{309}$ Ali A. Mazrui, The African: A Triple Heritage (Boston \& Toronto: Little, Brown and Company, 1986), 11.

${ }^{310}$ Mazrui, The African, 21.

${ }^{311}$ Mazrui, The African, 11. For full details of this curse, see Chinua Achebe, Things Fall Apart (New York: Fawcett Crest, 1989).

${ }^{312}$ Mazrui, The African, 11.
} 
of such a fight, to a greater extent, can be (and is) catastrophic. The obvious result, among other challenges, is the political unrest experienced in the continent. As Mazrui pointed out, "[I]n their immediate consequences decay and instability are a matter of lament." ${ }^{, 313}$ There is a clash between two civilizations - traditionalism and modernism. The chief, the representative of the ancestors, on the one hand, tries to seek compliance especially through the enforcement of customary sanctions. The laws of the modern nation-state, on the other hand, provide protection and freedom of the individual under the Constitution and other local and international human rights laws. By the demands of these western patterned laws, the sanctioning powers of the chief, in most cases, become ineffective and unrecognized. The chief, the "landowner" of the nationstate called Ghana, ${ }^{314}$ wanting to assert his authority in his area, usually comes into conflict with the modern laws of his own land. Mazrui was very optimistic for the future of such a situation. He envisaged that the end result of the conflict is victory, a win-win- success. "[I]n their immediate consequences decay and instability are a matter of lament. But in their longer term repercussions, they may be a matter of celebration" ${ }^{\prime 15}$ - celebration for the vanquished and the victor.

\footnotetext{
${ }^{313}$ Mazrui, The African, 21.

${ }^{314}$ The whole of chapter 21(Article 257-269) of the 1992 Constitution is devoted to "Lands and Natural Resources." The Constitution categorized landownership in the country into: public/state; stool/skin; clan/family; and private lands. However these four are generally classified under two broad categories: customary and public land ownerships. That notwithstanding, I must say that unlike other countries, technically, the government of Ghana does not have a land or society of its own. The land is traditionally the property of the ancestors of the chief and his people. Per the National Land Policy, 2002, appropriate payment of compensation must be paid to the chief, individual and family landowners for land acquired by the state. For a good understanding of Ghana's land tenure system, see Hayford J. E. Casely, The Truth About the West African Land Question. (New York: Negro Universities Press, 1969). See also Rebecca Sittie, "Land Title Registration: The Ghanaian Experience" (presented at the Shaping the Change XXIII FIG Congress, Munich, Germany, 2006), 1-11; Joseph Blocher, "Building on Custom: Land Tenure Policy and Economic Development in Ghana," Yale Human Rights and Development Law Journal 9 (2006): 166-202.

${ }^{315}$ Mazrui, The African, 21.
} 
The question that confronts Mazrui's reader is, but how? Mazrui provided two workable solutions. The first is what he termed as "the imperative of looking inwards towards ancestory" and the second is "the imperative of looking outwards towards the wider humanity." alternative theory of modernization modeled in African fashion offers an insightful means of understanding how modernity and western influences have undercut the sacred nature of the Akan chief. Implicit in Mazrui's argument is that the sacred position of the Akan chief in modern Ghanaian society, for example, evokes a bafflingly ambivalent concept.

Modernity has challenged indigenous African societies with a compelling dichotomization of traditionalism and modernism, chieftaincy and democracy. For Kimble, traditionally, morality or issues of rightness or wrongness in the society were not a matter of personal choice. "The criteria for any action was not individual profit nor even potential social betterment, but whether it had been approved by the ancestors and sanctioned by custom." ${ }^{, 317} \mathrm{~A}$ related challenge posed by modernity to the chieftaincy institution was the conflict between traditional authorities' allegiance to their indigenous states, on one hand and their loyalty to the modern nation state, on the other. Many authorities have attested that the creation of the modern African states was arbitrary and without any cultural and tribal continuities. Most of these states were carved out "with boundaries which bear no relation to ethnic limits or traditional kingdoms" ${ }^{\prime 18}$ and for European expediency and comfort. They were mainly "without reference to indigenous cultural boundaries. ${ }^{319}$ Prior to this, it has been indicated, the tribal ancestors and the deities played a significant role in the unification of the traditional state. They were

\footnotetext{
${ }^{316}$ Mazrui, The African, 21.

${ }^{317}$ Kimble, A Political History of Ghana, 128.

${ }^{318}$ Mazrui, The African, 242.

${ }^{319}$ Mazrui, The African, 242.
} 
responsible for the laws of the society, among other functions. Thomas J. Lewin observed among the Asante, for example, that "National unity was expressed through the institution of the Sika Dwa, or the Golden Stool, the sacred embodiment of the Asante people. New national oaths and festivals centered on the supremacy and glorification of the Asantehene's ancestors, and Akan deities symbolized the creation of the novel political order." 320

Economically, the creation of new wealth-oriented economies, trade and other new urban and peri-urban centers also weakened the power of the chief. The wider economic opportunities opened to all classes of people in the society gave new economic power to the commoner of the society. By virtue of the new economic opportunities of the time, commoners who were able to take good advantage and worked extra hard acquired new power and status in the society. The village chief, for example, was no longer the only person who controlled wealth in the ethnotribal community. The economic demands of the time brought with it new social obligations which challenged the power of the sacred chief and the traditional state. Members who severed their allegiance and commitment to the family and the larger society were seen as, among other sanctions, a disgrace and saboteurs respectively. Particularly in the society, the reverence deemed appropriate to the chief was uncompromising. "The community was all-important; the individual was bound to conform." 321 The new economic demands of the time, however, deemphasized an individual's commitment towards the extended family in particular and the society at large. Migration brought with it a new form of society based on diverse cultural, religious and socio-political leanings. The only thing common among members of the new found societies was the new economic drive.

\footnotetext{
${ }^{320}$ Thomas J. Lewin, Asante before the British: The Prempean Years, 1975-1900 (Lawrence: The Regent Press of Kansas, 1978), 11.

${ }^{321}$ Kimble, A Political History of Ghana, 128.
} 
The abolition of domestic slavery (though in the nineteenth century, in 1874) also marked a good modernizing period that challenged the existing and dominant economic order of the traditional society. The abolition did not only affect the economic status of the chief and slave owners (and would-be owners), as it meant loss of considerable labor force, but also gave a new power to slaves to substantially compete with their owners within the new economic system. Energetic and youthful members, who mostly did not occupy any significant socio-political position in the society but had worked hard to accumulate wealth, became influential in the society. Not only would their physical and youthful exuberance permit them to rally and organize destoolment challenges against any uncompromising chief, but the new economy had also supplied them with the wealth necessary to sustain such moves. The chief therefore, had his position increasingly threatened. The emphasis of authority, influence and power in the society was more of achievement rather than ascription. ${ }^{322}$

Especially in matters related to western education (which will be discussed shortly), the impact of modernity at the time challenged not only ordinary citizens but also the status of the chief. The seeming lack of education among most of the most of chiefs alienated them from their young and educated subjects. As the years went by, the disparity between the two (the chiefs and the educated youth) kept widening. The apparent lack of education among the chiefs, according to Kimble, for example, was responsible for the rise of several young and educated men who rose up to institute destoolment charges against the chiefs. Earlier in chapter one, it was indicated how, using Rathbone observation, in the areas within the Akan traditional areas, several

\footnotetext{
${ }^{322}$ Kimble, A Political History of Ghana, 130.
} 
destoolment charges were instituted. It was observed that between 1904 and 1926, an unprecedented 109 cases were preferred against Akan chiefs. ${ }^{323}$

Modernity and its influencing factors challenged the chief of every exclusive rights he had hitherto enjoyed. Indeed, what the chief could aptly term as the decadence western life, disorganized indigenous political structures of the society. The introduction of modern ways of doing things modeled in the western culture made it possible for the chief's subjects to defy his authority and also made the citizens appeare only as "nominal subjects" 324 of the chief. Evidence of this is seen in the transformation of asafo group as a warrior organization to a resistant movement - the core agents for collective political resistance in the Akanland.

According to Kimble, for example, modern ways of living and western education opened newer possibilities for young people to organize themselves against uncompromising chiefs. This situation led to the formation of asafo group, whose founders were mostly of the educated youth. Narrating the history behind the formation of the asafo as a resistant group, Kimble opined that by “1915 the 'youngmen' of Kwahu decided to make use of the traditional form of organization as an outlet for their economic grievances, and founded their own Asafo 'with the object to protest and resist against the imposition of heavy fines for breach of oaths, because nothing worthy ... was left as a result.", 325

However, it must be emphasized that the existence of the asafo company existed prior to colonialism. Asafo (asa, wars and fo, people, those who), among the Akan (and not only Akan but also later among the Ga, the Guan, the Krobo people), was a warrior group or organization

\footnotetext{
${ }^{323}$ Richard Rathbone, Nkrumah \& Chiefs: Politics Of Chieftaincy In Ghana 1951-1960, First. (Athens: Ohio University Press, 2000), 13.

${ }^{324}$ David Kimble, A Political History of Ghana: The Rise of Gold Coast Nationalism 1850-1928 (Oxford: The Clarendon Press, 1963), 466.

${ }^{325}$ Kimble, A Political History of Ghana, 470.
} 
that defended the interest of the ethno-tribal state. These were found in virtually every village of Akan land. Ideally, membership was opened to all able-bodied men (though occasional inclusion of few women was not strange), with the exception of the chief and his elders. As a well organized group, the asafo had its own hierarchical structures of organization with its own bylaws. Indeed, the asafo was a well structured military organization that had its own "flag, song, drums, horns, caps, emblems and its own post, the rallying place of the company, where all its paraphernalia were kept." ${ }^{, 326}$ This, without a doubt, was the asafo that existed in pre-western educational era.

It must, again, be added that owing to their important role as defenders of the society, the views and opinions of the asafo members were taken into serious consideration at the council of elders or any town or village meeting. They had a strong influence in the selection and destoolment of a chief. The leader of the asafo group, for instance, was an ex-officio member of the town counselors - a representative of the commoners of the society. ${ }^{327}$

Although by the early twentieth century the asafo had become a very powerful organization with the introduction of modern life, the hitherto warrior group, the movement for commoners, was transformed into a strong critic of the sacred chief's authority and person. The century can aptly be described as struggling period for the Akan chieftaincy institution. Within the first half of the century, virtually every colonial officer was said to have experienced or witnessed cases of destoolment. ${ }^{328}$ For example, it is on records that within four years of its formation in Kwahu, in 1919, the asafo group had made dramatic impact, so much so that it was

\footnotetext{
${ }^{326}$ Anshan Li, "Asafo and Destoolment in Colonial Southern Ghana, 1900-1953," The International Journal of African Historical Studies 28, no. 2 (1995): 327-357.

${ }^{327}$ For a good understanding of the role of the asafo and how they influenced the decision making process of the society, see Li, "Asafo and Destoolment in Colonial Southern Ghana," 333.

${ }^{328} \mathrm{Li}$, “Asafo and Destoolment in Colonial Southern Ghana," 346.
} 
seen as a treacherous and undesirable group which undermined all established authority within the socio-political arrangement of Kwahu. This indeed, brought about sever power struggle between the chief and the asafo most of whom were then highly educated.

The bitter acrimony between the chief and the educated and influential youth was not limited to the Kwahu area alone. Many of the traditional leaders felt challenged by the presence of the asafo group of youth. As early as 1913, for instance, tension had already mounted between the chiefs and elders of the Akim Abuakwa and the Asafo group. In this and other areas, the chief, seeing his sacred authority, the basis of his power in the society confronted, resorted to the use of traditional sanctions that in turn, widened the friction and animosity between him and his people. Many of these educated asafo groups and individuals, in some cases, were made to face the traditional sanctions of the land. In some cases, this created an ambivalent situation not only to the chief but even to the colonial government. It has already been established in this discussion that the presence of the colonial powers created a dual form of authority: the ethnopolitical leaders of the land and colonial administration. It has also been demonstrated that the activities of the colonizers undercut the authority of chief to the extent that his people with time became only "nominal subjects."

By delimiting and circumscribing the powers of the chief, the individual rights as a free citizen of the land were greatly enhanced. This, among others, as has been argued, promoted several resistances against the chief especially from the youth. What was problematic to the colonial government was that since the chief was an indispensable ally in the mobilization of the people, any attempt to destabilize his (the chief's) authority also had the ripple effect of affecting the smooth administration and organization of the colony. Thus, should the modern youth succeed in organizing destoolment against any unpopular chief, it would undercut the dual 
system of authority. ${ }^{329}$ In most cases, the colonial administration fearing the consequences of the erosion of the authority of the chief on their (colonialists) administration, enacted laws and Ordinances that sought to make destoolment less effective, if it ever succeeded. For example, on April 21, 1927, the colonial administration enacted The Native Administration Ordinance. This move sought to empower especially paramount chiefs whose positions were under constant threat from the commoners. The Ordinance, with the blessing of the colonial governor, sought to withhold recognition of destoolment. As expected, this did not go well with the local people hence the subsequent protest that ensued.

As has also been said earlier, in most cases, attempted destoolment cases were strictly punished by the chief. For example, the 1918 failed destoolment plots and the attack on the office of the Paramount chief of Akim Abuakwa was severely dealt with. Under conditions such as this, the chief and his elders became harsh and merciless towards offenders; instituting sanctions, which, in most cases limited the rights of the masses.

So powerful was the friction between the chief and the educated elites that in 1919 the chiefs and elders of Akim Abuakwa traditional council presented a petition to the Governor, "urging that every educated African, whether he be a lawyer, doctor, surveyor, engineer, or any other professional man, should be made to realize that he was still bound by traditional loyalties.. ${ }^{330}$ Part of the petition argued that western education or accident of wealth or other advantages were merely privileges and that these were not enough for one to lord it over others in the society, especially the leaders of the land. The chief and his officers argued that "It does seem to us that education in the proper sense of the word implies a contempt of the existing

\footnotetext{
${ }^{329}$ Kimble, A Political History of Ghana, 471.

${ }^{330}$ Kimble, A Political History of Ghana, 472.
} 
authority.' It was absurd for an educated man to refuse to go before his natural court of justice because the president or councilors were not equally educated: we beg to sound a warning., 331

So intense was also the pressure mounted by western education that most of the chiefs who could not resist the strong wave of it easily succumbed to its demands. Kimble reports that: "Toward the end of the century we find Hodgson writing approvingly that King Mate Kole had discarded native dress, 'by reason of his education and therefore more enlightened ideas', and supporting his application to wear a special uniform on occasions of state." ${ }^{332}$ The casting away of native customs including the wearing of chiefly costumes by the king was not only a downplaying of the native ones but also a silent admission that "European styles of dress were important as an outward and visible sign of inward and spiritual superiority." ${ }^{233}$ Indeed it was the European attempt to compel the indigenous societies of Africa to fit into the western model of modernization earlier on indicated.

\subsection{Western Education and the Sacred Authority of the Chief}

In the field of education, Colonialism and Christianity or what has been termed as EuroChristianity challenged the economic growth of the people of Africa. Education, like development, was understood in the European sense of the word, as embracing formal instruction in European-style schools. ${ }^{334}$ With the coming of the Euro-Christianity, "those who have been to school are said to be 'educated,' those who have not, are not, whatever their degree of proficiency in their own craft or trade, and whatever the period that has been spent in

\footnotetext{
${ }^{331}$ Quoted in Kimble, A Political History of Ghana, 472. For details see

${ }^{332}$ Kimble, A Political History of Ghana, 134.

${ }^{333}$ Kimble, A Political History of Ghana, 133.

${ }^{334}$ Kimble, A Political History of Ghana, 61.
} 
instructing them.”335 The traditional African sense of education went beyond the restricted Eurocentric sense of the word. It encompassed instruction in the complex intricacies of family and social system. Traditionally, the son of a farmer, for example, spent his days following the father to the farm until he became proficient enough and gradually acquired the father's profession. As Kimble explained, he studied when planting should be carried out, the right times for clearing and growing crops, and when harvest was ripe and ready for the gathering. ${ }^{336}$

However, the arrival of the Europeans, as already indicated, changed the African sense of education. European form of education did not take into consideration what Kimble refers to as "any response to pre-existing demands." ${ }^{, 337}$ What rather was introduced was an essential part of missionary programs. The earliest forms of education introduced were in response to the emerging demands for local people to function as interpreters and catechists for the propagation of the missionary message. Kimble narrated the whole motive, especially in the context of Gold Coast thus: "The earliest teachers met with indifference or active opposition, for the advantages of reading and writing, especially in a foreign language, were not so immediate apparent as those of trade, and they were considerably less relevant to the needs of African society."${ }^{, 338}$ As Mbiti has also noted, the establishment of early schools by the missionaries became nurseries for change. By the planting of the seed of the Gospel by the missionaries, he said, Christianity led the birth of the new revolution. ${ }^{339}$ The traditional religious concept and philosophical worldviews were rapidly challenged in ways that confronted the authority of the ancestors and, in turn, the

\footnotetext{
${ }^{335}$ Kimble, A Political History of Ghana, 61.

${ }^{336}$ Kimble, A Political History of Ghana, 61.

${ }^{337}$ Kimble, A Political History of Ghana, 61.

${ }^{338}$ Kimble, A Political History of Ghana, 61-62.

339 John S. Mbiti, African Religions and Philosophy, 2nd ed. (Oxford: Heinemann, 1969), 212.
} 
chief. To the modern educated youth, the belief in the ancestors, for example, came to be a useless relic of the past. The ancestors did no longer play any meaningful part in their (the youth) life.

Closely related to the issue of change in the people's perception was the introduction of agnosticism. The lack of belief in or concern for the role of the ancestors as well as other indigenous beliefs and practices in the community, with time became a "new form of belief" common in the traditional society. This "belief" has, over the years, been a great challenge to the authority of the chief. Through western education and other influencing factors, those who do not find consolation in any of the religious traditions currently prevalent in the society prefer to remain agnostic or atheistic. This development is found particularly among the most educated and tertiary students. Side by side with the issue of agnosticism is the erosion of the traditional cyclical concept of time. With the acceptance of agnosticism, most people tended to disregard the indigenous belief in the cyclical nature of the individual, thereby challenging the authority of the ancestors who are the main rulers of the society.

Again, prompted by the issue of urbanization and industrialization, the current demographic shifts, and increase in diversity-related awareness, there has been an increase in the reconsideration of the some of the customary practices and beliefs that are shrouded in taboos and religio-cultural discourse. The traditional society is, today, not populated or inhabited by members of the same ethno-tribal heritage alone. People from diverse ethnic, cultural and linguistic backgrounds are now an essential part of the traditional society which used to be tribal. Though these members are by law enjoined to abide by the customary laws and practices of their new place, such laws have often been frustrated on several grounds. The chieftaincy institution has not only been a victim of attack but also an institution of defense (defense of customary 
practices in particular). As has been indicated in the previous chapter, while the chieftaincy institution defends the demise of the aura of mystery that used to surround these customary practices, it also has to pay attention to the erosion of its own popularity and influence in these traditional societies.

\subsection{Chieftaincy and Post Independence Struggles}

The Akan chieftaincy institution continued to struggle even after colonialism. With the attainment of Ghana's independence, one of the most forcefully argued cases was the subsequent demise of the chieftaincy institution and its associated customary practices. For proponents of this argument, the attainment of independence, the forceful integration of several tribal states into one new nation-state, and the imposition of western values on the former colony, among others, were all signs of the transition from primitive lifestyle to a life of modernity. In January 18, 1960, for example, a popular American magazine, LIFE, following the independence of Ghana captioned one of its headlines as "Ghana's Leap from Stone Age to Eager New Nationhood." ${ }^{340}$ This leap, the paper claimed, was part of the ongoing democracy around the world. It was a departure from traditional rule to democracy. Democracy, it was believed, must replace the old hegemonic system of governance.

In the context of Ghana, an important outcome of the country's independence was what was seen as the nationalist leaders' assault on the chieftaincy system. Under the Nkrumah regime, anti-chieftaincy hegemonic tendencies intensified in the country. Part of the struggle was to integrant, as best as possible, the chieftaincy institution into the then new nation-state whose members still, though nominal as has been argued earlier, still owed allegiance to their ethnopolitical leader, the chief. Stalwarts of the then ruling Convention People's Party used several

\footnotetext{
340 “Ghana's Leap from Stone Age to Eager New Nationhood," LIFE 48, no. 2 (January 18, 1960): 78-91.
} 
counter-hegemonic discourses meant to reappropriate chiefly power into the hands of the leaders of the party and to a less extent the common people of the new nation state. With the struggle for independence of the new states, the dominant ideology of the CPP, Nkrumah's ruling party, was that the chieftaincy institution must be seen only as an essential part of the new nation and not as the single most significant institution of governance. For the nationalist leaders, with or without the chief, the newly born democratic state must move on. The resolve, as the Accra Evening News editorial reported it, was that "We have decided to carry on the struggle with or without the Chiefs... we shall no longer continue to put our confidence in chiefs. ${ }^{341}$ A chief who openly supported the opposition party was sure of receiving open confrontation and abuse from the members of the ruling party.

Even if the party did not encourage its members to openly challenge and abuse such a chief, it could not guarantee the chief's protection from members who decided to confront him. The party stated their position thus: "We are not... in favour of our Nananom [chiefs] being hooted at, booed or stoned, but it is natural when a king condescends to take the role and perform duties of an ordinary citizen, then of course he must take the consequences." ${ }^{342}$ Of course, naturally this is an honest position taken by the party. As a sacred person, the demands of the office set the chief apart from his subjects and must be held as such. What is problematic in this position is that it rather strengthened the already apparent lack of respect shown to the chief as such people who did so received covert support of the party. It must even be added that notwithstanding this seeming neutral position adopted by the party, there were occasional open

\footnotetext{
${ }^{341}$ Quoted in Rathbone, Nkrumah \& Chiefs, 26. See also the September 6, 1950 edition of the Accra Evening News.

${ }^{342}$ These were the strong warning issues to chief who openly showed their lack of support for the then ruling CPP government of Nkrumah, Ghana's first president. See Rathbone, Nkrumah and the Chiefs, 26. For detailed information about this warning see Accra Evening News, August 25, 1950.
} 
incitements to press destoolment charges against anti-CPP chiefs. ${ }^{343}$ For the leaders of the party "[D]ue respect should be given to them [chiefs]; but of course, if a chief does not show the same tendency towards his people then of course the Party cannot be blamed for any conflict that ensues. It must be said that this is the age of the Common Man." ${ }^{344}$ The common man, as Rathbone explains, obviously refers to the supporters of the ruling party. This, indeed, is a significant point of interest. Per the demands of the new nation state, royalty is achieved and not ascribed. A new meaning must be given to who a royal is. One's royalty is determined by one's success in the nation state. The new nation state, through western education and equality of its members, presented opportunity for every "commoner" to rise to positions of honor. As Emmanuel Akyeampong writes, among the Asante:

The elderly royals vowed that they would not send their children to school to be beaten by amanfrafroo (foreigners). The parents of royals whom Prempeh insisted should be sent to school would send an afona (servant) to school with them. When they infringed school rules the afona and not the royal took the corporal punishment. This was detrimental to the future of the royal families. They did not send their wards to school. It was the commoner families who became the major beneficiaries of Western education. ${ }^{345}$

As has already been indicated in chapter one, Nkrumah's government struggled with the chiefs and the local people more than he even struggled with the colonial leaders. The question that needs to be asked is why so? Nkrumah by all account was a good nationalist leader with all the good intentions of bettering the life of the people of the new nation state - Ghana, something the chief had always desired in pre-colonial times. It must then be said that, among other reasons, as

\footnotetext{
${ }^{343}$ Rathbone, Nkrumah \& Chiefs, 27.

${ }^{344}$ Rathbone, Nkrumah and the Chiefs, 33.

${ }^{345}$ Of course, notwithstanding these challenges in the royal houses, the king, Prempeh I took advantage of the new opportunities of the time and gave some of the young royals such as Kwadwo Bonsu and Henry Prempeh, the best education of the time including further study in London in 1926. These young royals studied medicine and law respectively. See Akyeampong, "Christianity, Modernity and the Weight of Tradition," 299.
} 
has just been indicated, the ruling government saw the chieftaincy institution as hegemonic. As Rathbone noted:

The CPP was also a party which had been impressed by at least some of the thrusts of Marxism-Leninism. From the end of 1950, and for the first time, the anti-chief rhetoric of nationalism in the Gold Coast began to talk of feudalism. The newspapers of the party, the Accra Evening News, which first appeared before the formation of the CPP in September 1984 as a radical news sheet, constantly upbraided chiefs for their "oppression of the masses" and especially for their "collaboration with the imperialists." 346

Nkrumah himself was a commoner and a beneficiary of western education who rose to a leadership position. From the then "unknown" place in the western part of the new nation state, with no traces of royalty, Nkrumah rose to the position of power. His apparently low status in the traditional society did not serve as a setback in his effort to challenge the traditional authorities of his day whose authority and power he saw as hegemonic. ${ }^{347}$ Undeniably, Nkrumah challenged not only the "traditional" hegemony but also all forms of hegemony that set limitations on the way of the individual. Although he described his early years as a good member of and baptized into the Roman Catholic faith, the religious tradition which he admitted he owed so much "thank you" as a child, he later in his life sought his liberation outside of this church and her doctrine. In his autobiography, he recounted his experience thus:

I took my religion seriously and was very often to be found serving at Mass. As I grew older, however, the strict discipline of Roman Catholicism stifled me. It was not that I became any less religious but rather that I sought freedom in the worship of and communion with my God, for my God is a very personal God and can only be reached direct. I don't find the need of, in fact I resent the intervention of a third party in such a personal matter. To-day I am a non denominational Christian and a Marxist socialist and I have not found any contradiction between the two. ${ }^{348}$

\footnotetext{
${ }^{346}$ Rathbone, Nkrumah and the Chiefs, 22.

${ }^{347}$ Leslie Rubin and Brain Weinstein, Introduction to African Politics, 2nd ed. (New York: Praeger Publishers, 1977), 24.

${ }^{348}$ Kwame Nkrumah, Ghana: The Autobiography of Kwame Nkrumah (New York: International Publishers, 1957), $11-12$.
} 
As "a non-denominational Christian and a Marxist socialist," it is not clear if Nkrumah was influenced by some amount of Antonio Gramsci's writings and philosophical ideas. Nowhere in his writings or speeches did Nkrumah give any such clue. However, as a Marxist socialist, the possibility of having been introduced to this great Marxist thinker cannot be ruled out. ${ }^{349}$ In fact, Nkrumah himself acknowledged in his autobiography that his quest for "finding a formula" for untying the knot of colonialism and imperialism introduced him to thinkers such as Hegel, Marx, Lenin, Mazzini and Garvey. ${ }^{350}$

To be able to effectively rule the newly created nation state of Ghana, Nkrumah developed a set of political, socio-cultural, and ethical ideologies "as the 'new' norm for his decolonization agenda that has something to do with hegemony." ${ }^{351}$ Part of it was to unite a society already polarized due to the people's allegiance to their indigenous leaders instead of the new leaders of the nation state. The only way out, with time, was the repudiation of existing cultural norms and values which served as the basis of oppression and conflict. This, as Gramsci said, must be replaced with new norms and values which include institutions, practices, beliefs, etc. Seeing the chief as stumbling to this agenda, Nkrumah and his government established several counter-hegemonic ideological discourses aimed at appropriating and challenging the hitherto sacred powers of the traditional state. Important chiefly metaphors and paraphernalia, for instance, came to be appropriated by the party and its supporters. "The gong-gong, which was used to summon the people, was often beaten by a party official, party rallies competed with traditional durbars, party drumming groups competed with those in the chiefs' courts, and village

\footnotetext{
349 Robert Yaw Owusu, Kwame Nkrumah's Liberation Thought: A Paradigm for the Religious Advocacy in Contemporary Ghana (Trenton and Asmara: African World Press, 2006), 56.

${ }^{350}$ Nkrumah, The Autobiography, 45.

${ }^{351}$ Owusu, Kwame Nkrumah's Liberation Thought, 56.
} 
development committees were chaired by party officials." ${ }^{, 352}$ This account indicates the obvious frustration the Nkrumah government gave to the chief and his elders. The deliberate use of the gong-gong, an important royal channel of communication, for instance, was not only a reclamation of chiefly paraphernalia by the party, but also an affront to the authority of the chief. In his Religion and Culture, Christopher Dawson outlines the significant role of king due to the kingly paraphernalia. ${ }^{353}$ According to Dawson, throughout history the distinctive character of the kingly office has been emphasized by all societies that practice it and "that even to-date the crown and scepter which are the symbols of this sacred character remain the emblem of royalty as they were 5,000 years ago.. ${ }^{354}$ Indeed I cannot but agree with this assertion. As Eliade, in his discussion on hierophanies, also theorized:

The forms of hierophanies vary from one culture to another. The matter is complicated for, throughout the course of history, cultures have recognized hierophanies everywhere in psychological, economic, spiritual, and social life. There is hardly any object, action, psychological function, species of being, or even entertainment that has not become a hierophany at some time. Whatever humans come in contact with can be transformed into a hierophany. Musical instruments, architectural forms, beasts of burden, and vehicles of transportation have been sacred objects. In the right circumstances, any material object whatever can become a hierophany. ${ }^{355}$

Traditionally the gong-gong and the drum were not only important traditional musical accoutrements but were also relevant means of communicating with the spiritual forces of the land. Stephen Davis, for example, has observed that in indigenous African religious traditions, drums are known not only to transmit messages between God and people, but are also essential

\footnotetext{
${ }^{352}$ K. Boafo-Arthur, "Chieftaincy and Politics in Ghana Since 1982,” West Africa Review 3, no. 1 (2001).

${ }^{353}$ Dawson, Religion and Culture, 109.

${ }^{354}$ Dawson, Religion and Culture, 109.

${ }^{355}$ Merci Eliade and Lawrence E. Sullivan, "Hierophany," in Encyclopedia of Religion, vol. 6 (New York: Macmillan, 1987), 313.
} 
instruments in the ritual healing process. ${ }^{356}$ These are therefore part of the sacred objects of the people. Thus, CPP's attempt to appropriate these chiefly objects were meant not only to frustrate the leaders of the land but to also take over their (the chiefs) "natural rights" to lead the indigenous people.

The greatest of these challenge was the "radical nationalist government's attempt to destroy southern chieftaincy. ${ }^{, 357}$ Under the government of the CPP, according to Johannes Knierzinger, the whole legal basis of what he refers to as the neotraditional states were eroded and substituted by a governmental system of command and interference. ${ }^{358}$ The struggle with the chief greatly surpassed what existed during the colonial rule. ${ }^{359}$ "A central feature of that story was those governments' attempt to break, co-opt and coerce chieftaincy. ${ }^{360}$ For example, prior to independence, it is recorded that on August 6, 1950, the acting chairman of the party (CPP), Komla Gbedemah, explained to party faithful and Ghanaians in general that the CPP party had nothing against the chiefs, but was rather fighting in their interest - to liberate them. For Gbedemah: "Those who of them who will be reasonable and willing to be emancipated and will come to our side we will bring home with honour.. those of them who... choose to remain stooges... of imperialists must be left to their fate. ${ }^{„ 361}$ Thus, the society was filled with tension, animosity and polarization. This hostile attitude towards the non-CPP chief not only undermined

\footnotetext{
${ }^{356}$ Stephen Davis, Reggae Bloodlines: In search of the music and culture in Jamaica (New York: De Capo Press, 1992), 34.

${ }^{357}$ Rathbone, Nkrumah \& Chiefs, 8.

358 Johannes Knierzinger, "Chieftaincy and Development in Ghana: From Political Intermediaries to Neotraditional Development Brokers" (Working Paper, Department of Anthropology and African Studies, n.d.), 10.

${ }^{359}$ Knierzinger, "Chieftaincy and Development in Ghana," 11; Rathbone, Nkrumah \& Chiefs, 8.

${ }^{360}$ Rathbone, Nkrumah \& Chiefs, ix.

${ }^{361}$ Rathbone, Nkrumah \& Chiefs, 25.
} 
his authority, but also made him equally aggressive to his nominal subjects. This was seen as limitation of the individual human rights in the context of globalization and international human rights laws.

\subsection{Globalization and its impact on local cultures}

With societies of the world coming together as one global village, the basic assumption and prediction have been that there will be an ever more interconnectedness of all societies and that all restrictions or barriers will eventually be removed. This, the prophets of globalization predict, would lead to the world witnessing a transnational dissemination of ideas, languages, and culture, goods and services, capital, etc. With this in mind, the idea is that closely knit communities, for example, will be forced to open up to new social relations. This, undeniably, is the case of most (if not all) indigenous communities of Africa. In the context of Africa, the coming together of several cultures, an essential aspect of globalization, has been described by some observers as an inevitable world revolution. It is a revolution which is such that no society or group of people can remain unaffected by it. ${ }^{362}$ With globalization, indigenous societies of Africa in particular have been entangled in the web of what Mbiti refers to as a new rhythm of modern life which is so intense that nothing can halt or slow its rapid tempo. The only way out for Mbiti, is that "the man of Africa must get out and dance, for better or for worse, on the arena of world drama." 363 To be able to understand how globalization has affected the Akan chieftaincy institution, I seek to analyze two of the features of globalization and how these have impacted on local cultures and the authority of the chief.

\footnotetext{
${ }^{362}$ Mbiti, African Religions and Philosophy, 211.

${ }^{363}$ Mbiti, African Religions and Philosophy, 211.
} 


\subsubsection{Detribalization of the Indigenous Societies}

Globalization challenges the traditional mapping of geopolitical territories. An important feature of globalization is the deterritorialization of indigenous cultures - the growing presence of social forms of contact and involvement which go beyond the limits of a specific territory." 364 Globalization weakens the ties between cultures and places. It presents the challenge of deemphasizing national sovereignty. Anthropologists, for example, have argued that the coming together of people and cultures for purposes of economic, trade, sports, politics, etc, removes the cultural subjects and objects from certain location and space. By this interaction, certain aspects of culture in one society transcend their specific territorial boundaries. Unfortunately for Africa, as in most indigenous societies, (though not so unfortunate in all cases), its cultural values and aspects have been an unwilling participants in this cultural contests. As Achile Mbembe rightly puts it, the "process of reterritorialization itself is neither the simple outcome of volunteerism nor the effect of structural determinism. Driven by social actors in negotiation and interaction with formal, informal, and overlapping boundaries, this process is constituted of and through both discursive representations and material practices." 365 In such a contest, these indigenous cultures have rather given way to more the "powerful," intimidating and influential cultures particularly of the west.

An important consequence of this revolution is what Mbiti has described as detribalization. By this, indigenous modes of life have been neglected or undermined, to the extent "that tribal identity is fading away since other identities are making claims on the

\footnotetext{
${ }^{364}$ Gil-Manuel Hernàndez i Martí, “The deterritorialization of cultural heritage in a globalized modernity,” Journal of Contemporary Culture, no. 1 (2006): 93-107.

365 Achille Mbembe, "Ways of Seeing: Beyond the New Nativism. Introduction," African Studies Review 44, no. 2 (September 2001): 1-14.
} 
individual and the community." ${ }^{366}$ The youth in particular, have been most susceptible to these influences. They are entangled in the web of globalization. ${ }^{367}$ However, the more they become more global the more they are cut off from, and place less emphasis on, their tribal solidarity. The call for Africa to be a part of this globalized village has rather deterritorialized its cultural boundaries. This has led to the infiltration of "undesirable" cultural norms that have dispossessed the chief of most basic sanctioning powers. As Mbembe has again observed, the transnationalization of African economies, contrary to the purpose of expansion of foreign direct investment or intensified deployment of information technologies, is "a result of the emergence of new extractive structures and mechanism, the aim of which is to convert territories into resources and power." ${ }^{368}$ The effect of all these developments is that traditional societies have been forced to open up to the competing world cultures which sadly have undermined the indigenous cultures. The result is that since the authority of the chief is dependent of these cultural continuities, any effects on the cultures of the people, in turn, affect the power of the chief.

\subsubsection{Technological Advancement and Local Cultures}

Closely related to the problem of detribalization is technological explosion. With the rapid advancement in technology especially in the field of information and communication technologies, the world has become more and more connected than it was before. This rapid dissemination of information has had its effects especially of connecting and bringing the world closer together in time and space. Societies are getting ever more closer, developing ways in

\footnotetext{
${ }^{366}$ Mbiti, African Religions and Philosophy, 212.

${ }^{367}$ Laura L. Adams, “Globalization of Culture and the Arts," Sociology Compass 1, no. 1 (2007): 127-142.

${ }^{368}$ Mbembe, "Ways of Seeing," 4.
} 
which people in different countries are connected to one another. What this means for local cultures is that through the internet, satellite television, mobile phones, and consumer goods (and obviously not only these), the indigenous societies of African have increasingly been exposed to predominant western and other societal values and ideals. ${ }^{369}$ Contemporary African youth are indeed, under the compelling influence of globalization such that they have developed "a bicultural identity or perhaps a hybrid identity. ${ }^{370}$ Citizens have been challenged by global consciousness and in most cases live as members "phenomenal worlds [that are] for the most part truly global." 371

In the final analysis, through what the individual sees and hears from other societies, it is he or she who determines who he or she is; what he or she wants to be or how he or she wants to be included within the wider social network. The resulting consequences of all these is that as Arnett has observed:

part of one's identity is rooted in the local culture while another part stems from an awareness of one's relation to the global world. The development of global identities is no longer just a part of immigrants and ethnic minorities. People today especially the young develop an identity that gives them a sense of belonging to a worldwide culture, which includes an awareness of events, practices, styles and information that are a part of the global culture. ${ }^{372}$

What is worrisome about this is that in a society that places so much emphasis on the importance of the communal life or cooperate existence (of which the chief presides), any deconstruction of who the individual is, as result of what he or she sees outside, has its impact on the authority of the chief as well. The deconstruction of one's identity "means that individuals are severed, cut

\footnotetext{
${ }^{369}$ Ifeanyi J. Ezema, "Globalisation, Information Revolution and Cultural Imperialism in Africa," Information, Society and Justice 3, no. 1, 11-22 (January 2010).

${ }^{370}$ J.J. Arnett, "Psychology of Globalization," American Psychologist 57, no. 10 (2002): 774-83.

${ }^{371}$ Anthony Giddens, Modernity and self-identity: Self and society in the late modern age. (Cambridge, England: Polity Press, 1991), 187.

${ }^{372}$ Arnett, "Psychology of Globalization," 777.
} 
off, pulled out and separated from corporate morality, customs and traditional solidarity." ${ }^{373}$ The individual has little or no link to his ancestral past and does not see the need to belong to it. To be sure, he is only a nominal subject of his ethno-tribal sacred chief. This indeed is the challenge that the contemporary Akan chieftaincy institution faces. The traditional maxim anoma ye kese a egina ne ntakera (the feathers of the bird contributes to its size) has a greater influence in understanding this. Every powerful chief relies and rallies the support of the people he controls. A powerful chief must not only have an aura of mystic historicity as has been discussed already, but must control a large area and subjects.

Thus far, it is quite realistic to say that the seeming detribalization and explosion in technology and information as part of phenomenal changes in the society affect not only the power of the chief but also contributes to its seeming demise. That notwithstanding, the institution has proved itself to be a formidable force to reckon with it. As Kimble has argued, despite all these forces making for social change "the strong sense of family obligation, the pull of the home village, the influence of traditional religion, the tenacious attitude towards land - all these and many more remained as strong eddies and cross-currents in the rising tide of nationalism....perhaps the most significant is the role of the Chiefs. ${ }^{, 374}$

\subsection{Conclusion}

The discussion in these last two chapters in particular has given the impression that the Akan chieftaincy institution is at the crossroads (suffering from the shocks of colonialism, religious pluralism, modernity and their attending effects like deconstruction of the sacred metaphors of the sacred chief). This chapter has confirmed that in spite of the compelling forces

\footnotetext{
${ }^{373}$ Mbiti, African Religions and Philosophy, 214.

${ }^{374}$ Kimble, A Political History of Ghana, 166-167.
} 
of social change which have called for a redefinition of the individual self in the Ghanaian societies, it is intriguing to see how resilient the custom defining who the indigenous Akan is has been. Nevertheless, the hitherto sacrosanct office of the Akan chief has been greatly affected. In the chapter that follows, the study addresses the second part of the question guiding this work: How has the religio-cultural worldview regarding the position of the Akan chief been used as a hegemonic tool and, in turn, affected the religious human rights of the people who live in Akan areas? 


\section{CHAPTER VII: CHIEFTAINCY AND HUMAN RIGHTS: ISSUES OF CONCERN}

\subsection{Introduction}

The discussion in this chapter seeks to give a critique and analysis of the issues that have arisen in the previous chapters and also seeks to raise some concerns of human rights issues. The chapter does not purport to comprehensively address the human rights issues that are raised as doing so, within the space and time available, would be an overwhelming task in a single work of this nature. Thus, the chapter does not also seek to find a comprehensive solution to the problem identified in this study. Rather, since coherent solutions can only be found by seeking to understand the challenges and prospects in their complexity and interconnectedness, this chapter rather attempts to focus on bringing awareness of the existence of the complicated nature o the interface between religion, tradition, modernity and religious human rights laws. What I seek to do in this chapter is to discuss the ambivalent situation within which the chieftaincy institution has found itself especially in the context of human rights. This notwithstanding, the discussion will yield itself towards some suggestions that are necessary for policy implementation. In doing so, an attempt is made to address the second question that guides the study: What challenges has the clash between traditionalism and modernity presented to the human rights of the individual in the Akanland? I answer this question by looking at some specific cases from the Akan traditional societies and how the individual, the chief and the central government have responded to them and the implications of such as response.

\subsection{Desacralization of the Position of the Akan Chief}

The discussion so far has provided a good indication of how the hitherto sacred nature of the chief has been challenged. A significant challenge that modernity, religious pluralism and, indeed, international human rights pose to the office of the Akan chief is the desacralization of 
the nature of the chief. An important impact of globalization within the religious realm is what might be termed as "global religions." Globalization has challenged the hitherto enclaves that most indigenous religious traditions formed and the monopoly they previously enjoyed. Virtually, all religions now appeal to international dimension of its teaching and support. The distinctiveness of these traditions has given way to a much more globalized version of it. One such uniqueness that has been challenged is the communal nature of indigenous religious traditions. That being the case, the religious nature of the chief has also been challenged on this ground. As a leader of the ethnic group, the chief's "sacred" position founded on his religious function has been losing much emphasis giving way to only his political role, even if nominally. Earlier in chapter one, it was argued that with modernity and the coming together of societies, there has been a confrontational relationship between religious and non-religious concept of reality. Using the Dohrman W. Byers' concept of sacred person, the single most important question that was raised was, what is it about other human beings that make them more sacred than others?

Again, the discussion in chapter in five drew attention to the fact that the coming of Christianity which competed with the indigenous traditions of which the chief was the main custodian also undercut the position of the chief such that he no longer was considered as sacred. The challenges the chieftaincy institution went through especially during the post colonial era up to now and the fact that the attitude of most of the chiefs do not conform to demands of their office has also been a challenge to the authority of the chief. This is particularly seen especially in the light of the demands of the contemporary human rights instruments. It worth noting that human rights does not give recognition or any recourse to single individuals or authority as overly important. To put it bluntly, human rights instruments are not respecter of authorities or 
certain individuals simply by virtue of their "privileged" positions. Indeed, in human rights instruments, "all persons are entitled to equality before the law and equal protection of the law." ${ }^{375}$ This has indeed, eroded the spiritual basis of the chief upon which a major part of his respect and authority in the society depended. Contemporary international human rights instruments (to be distinguished from indigenous human rights ${ }^{376}$ ) give the individual an increased sense of autonomy, to be free from the entanglements and interference from traditional authorities. As the study has shown, the support given by the state agents makes it difficult for the full realization of these human rights demands. In the next section, I discuss how the alliance forged between the state and the chief usually gives rise to the limitation of the individual human rights.

\subsection{The Chief as an Ally of the Government}

The UN Declaration on the Elimination of All Forms of Intolerance and Discrimination Based on Religion or Belief (herein after called Declaration on Religion) calls for the inherent equality of human beings and the principle of equality before the law. It encourages member states to desist from showing any form of intolerance and discrimination in the treatment of religious activities and life of its citizens. Discrimination, in the context of Article two of the said Declaration means "any distinction, exclusion, restriction or preference based on religion or belief and having as its purpose or as its effect nullification or impairment of the recognition, enjoyment or exercise of human rights and fundamental freedoms on an equal basis." Thus, breaches of this instrument occur when a state identifies itself with a particular religious

\footnotetext{
${ }^{375}$ Nazila Ghanea, "Religion, Equality, and Non-Discrimination," in Religion and Human Rights: An Introduction (Oxford: Oxford University Press, 2012), 212.

${ }^{376}$ Tweneboah, "Religious Human Rights."
} 
tradition, beliefs, agents, figures or personalities. As Nazila Ghanea has aptly pointed out, "When a state declares a formal position with regard to a particular religion or belief, demands of it to ensure the rights of the others merits sharper consideration., ${ }^{377}$ What is problematic with this article is seen in the context of Ghanaian political landscape. The unofficial affiliation which the leaders of political parties show towards the indigenous leaders, the chiefs, makes it difficult to deny any covert state support of the indigenous religions. To be able to understand this and the implications of such affiliation for the individual human rights it is important that I recap what has been found already in this study.

The discussion especially in the last two chapters has given enough bases to conclude that the office and authority of the Akan chief, even within the modern nation-state, does not operate in an empty political vacuum. It is given open and covert state support. Notwithstanding the seeming separation of powers of the state from the traditional chief's office, contemporary chieftaincy institutions, due to the reasons given in the previous chapter, still has links with the leaders of the national politics. Throughout this study, it has been argued that since colonial period, there has been an overlapping network of power struggle due to the dual system of authority in the society the result of which is the abuse of the rights of the individual.

The Constitutions of most African countries prevent the chief in engaging in active party politics. In Ghana, article 276 (1) of the 1992 Constitution concisely states that: “A chief shall not take part in active party politics; and any chief wishing to do so and seeking election to Parliament shall abdicate his stool or skin." The failure of the modern nation-state's institutions of African societies to adequately address the fears and hopes, aspirations and anxieties, and worries and concerns, among others, of their members, however, has made some of these legal

\footnotetext{
${ }^{377}$ Ghanea, "Religion, Equality, and Non-Discrimination," 211.
} 
requirements that seek to limit the involvement of the chief in the party political affairs ineffective. This weakness of the modern nation-state has rather made the chief an indispensable competitor and ally in the governance of the society. The chief's office has become formidable and crucial in the democratic dispensation of the modern nation-state not only because of the people's solidarity in their ethno-tribal roots but also the chief is seen as an important development partner of the state. The institutions of the modern state are not adequately equipped to deal with the concerns of the masses, to evenly and fairly distribute the common wealth and resources of the state. This has led to disappointment and disaffection among the chief and his people in most ethno-tribal societies. Under such conditions, the people, and even the government, rely on the office of the chief to fill in these developmental gaps. ${ }^{378}$

As is usually expected, the attempt to suppress a people's progress, concerns and beliefs - which are intricately tied to their religion, only turns to solidify such commonality. The ethnotribal solidarity under the person and office of the chief has, thus, been employed for the successful governance of the society. Conscious of the fact that the people are always in constant touch with their chief, the politician appropriates the influence inherent in the chief's office to canvas for votes. The chief, therefore, becomes an indispensable ally of governance and development. In Ghana, even Nkrumah himself who earlier on in this discussion it was indicated that he persecuted the chiefs, was largely seen as drawing his charismatic inspiration from the noble office of the sacred chief. As Apter has noted, "the chieftaincy as a sanctional source, a symbolic referent, an integration integer, and for sub-ethnic and ethnic definition, represents the

\footnotetext{
${ }^{378}$ Johannes Knierzinger, "Chieftaincy and Development in Ghana: From Political Intermediaries to Neotraditional Development Brokers" (Working Paper presented at the University of Mainz, Department of Anthropology and African Studies, 2011), 5-47.
} 
orientational base out of which the charismatic authority of Nkrumah...has developed."379 Indeed this has been the trend since independence era. For purposes of easy and effective mobilization of the masses, the office of the chief has subtly and mostly openly been employed by successive governments. Under such conditions, as Dieter Senghaas has also aptly observed, "gaining political power by instrumentalizing religion; activating the religious community for reasons of solidarity, revitalizing one's own traditional values, struggling against the Western 'devil' or a mixture of these elements" ${ }^{\prime 380}$ are possible options.

The chief, recognizing his indispensability and the crucial role he plays in the affairs of the new nation-state, also sometimes manipulates what is seen as his religi-political powers to his own advantage. In a society where the foundational basis of the chief's power seem to be shaky as has been discussed in the previous section, the chief employs tactics that would provide enough bases to demonstrate that in spite of the challenges his office is undergoing, it is still the preferred option for political organization, and that the office contains values that do not contradict modern ways of political life. In this case, the chief engages in some apologetic rhetorics that seek to protect and legitimizes not only his "sacred" position but also his "profane" actions.

For one thing, contrary to the demands of the Declaration on Religion as well as the 1992 Constitution of Ghana as quoted above, the chief has gained the support (even if covertly) of the leaders of modern nation-state - those mandated to deal with cases of abuses of chiefly powers and equality of all religions. In fact, to the chief, he is the hand that feeds the politician and therefore he (the chief) is consciously aware that any attempt to bite him might cause serious

\footnotetext{
${ }^{379}$ David E. Apter, Ghana in Transition (Princeton \& New Jersey: Princeton University Press, 1972), 108.

${ }^{380}$ Dieter Senghaas, The Clash Within Civilizations: Coming to Terms with Cultural Conflicts (London and New York: Routledge, 2002), 36.
} 
self-inflicted political starvation to the politician. In March 2010, for example, following the impasse between the Techimanhene and the Tuobodomhene (chief of Tuobodom), the Asantehene, whose stool the Tuobodohene pays allegiance, issued a stern warning to the government thus:

I am closely watching with keen interest and I will kidnap the so-called Techimanhene and bring him to the Manhyia Palace whenever he storms Kumasi if the government fails to take action against him for kidnapping Tuobodomhene, Nana Asare Baffuor, anytime soon. After kidnapping the Techimanhene, then the government, who has surprisingly kept mute about the atrocities committed by Nana Akumfi Ameyaw against the Tuobodomhene, can decide to come and face me here. ${ }^{381}$

Following this warning the national security agents and some members of the government met the parties involved for possible solution to this issue. While it is quite expedient to diplomatically deny that the spontaneous response from the government has nothing to do with the Asantehene's warning, at the popular level, it became obvious to Ghanaians that the political consequences of the statement was a motivating factor for the government to act swiftly.

The unofficial and covert support given to the chief has two main implications for international human rights, especially the rights of the individual. First, the state support given to the chief (even if it is indirect or unofficial) challenges the call for member states to abide by the demands of international human rights instruments. It is a subtle contradiction and affront to the tenets of the Declaration on Religion, for example. As has already been indicated at the beginning of the present discussion, the state is the one mandated to seek the protection of the dignity of all citizens especially in matters of religion. Any attempt to support the chief who is

\footnotetext{
${ }^{381}$ This warning was issued in response to what the Asantehene saw as the government's failure to address the alleged kidnapping, manhandling and humiliation of the Tuobodomhene, one of his sub-chiefs of the Asantehene. For the full story, see I.F. Joe Awuah Jnr., "I Will Kidnap Techiman Chief: Otumfour Warns Mills," Daily Guide,, March 16, 2010. For a detailed background information to this several centuries old impasse, see Seth Tweneboah, "Religious Human Rights in the Techiman Traditional Area of Modern Ghana" (MPhil Thesis, unpublished: University of Ghana, 2010), 99-100; Mansah Prah and Alfred Yeboah, "Tuobodom Chieftaincy Conflict in Ghana: A Review and Analysis of Media Reports," The Journal of Pan African Studies 4, no. 3 (March 2011): 20-33.
} 
also the de facto custodian of the indigenous religion of his area is a sign of enhancing the position of the chief and his religion. The second implication is drawn from the first. While it is proper to save indigenous religions from their seeming loss of strength as the tradition is disadvantaged in terms of the aggression competition of religious groups for membership in the modern state, it is also equally problematic if one takes the Declaration on Religion into consideration. The chief is not just a political leader of his ethnic group, but he is also a spiritual leader of his people. As such using state resources and powers to support him is by extension a support of his religion which breaches the principle of equality and non-discrimination as part of religious rights.

\subsection{Chieftaincy and Democratization of Tradition}

Another important finding from this study has been that with modernization comes democratization of tradition. The Akan chief usually appeals to his ancestral tradition as a justificatory basis of his actions. But in reality many of such appeals are only an exaggerated application of ancestral legacy as these actions usually tend to be merely a hollow pretext to the chief's personal aggrandizement. Such actions are mostly inclined towards the destruction of the new ideals (democracy) the modern society has fashioned. Thus democracy, to some extent, challenges the traditional social and moral foundations of the indigenous societies.

The study has revealed that among the reasons offered by the chief for his lack of willingness to change has been due to the fact that the position he occupies, in most cases, demands an unbending response to any uncritical call for change. For the most part, succumbing to the demands of the day means destroying the foundation of his authority and offending the ancestors whose positions he occupies. Under such conditions, using the support base of the modern nation-state and the amount of influence he wields in his territory as his springboard, the 
chief resorts to the protection of his ancestral legacies through the use of apologetic mechanisms. This also accounts for the manner with which the chief responds to competing external influences by means of traditional protectionism while consolidating his chiefly power and authority as the same time. In most cases, this leads to the abuse of the rights of the individual citizen.

Contemporary demands of the society especially citizens' awareness of international human rights laws and the acceptance of democratic principle, despite the occasional challenges associated with it, have confronted the office of the chief to be more democratic. The study revealed that the Akan chief does not rule in isolation as power trickles down from the spiritual forces down to the people. Again the chief is supported by his council of elders. As such, the chief takes decision in consultation with his elders, thus, making some observers assert that the office of the chief is as democratic as any other society one can imagine. ${ }^{382}$ This indeed has been a contentious claim over the years. Granted that this is the case, it is still undeniable that the factors of change this study sought to explore have redefined the chieftaincy institution in terms of democratic principles. As Sally Merry has rightly observed "[T]he localization of human rights is part of the vastly unequal global distribution of power and resources that channels how ideas develop in global setting and are picked up or rejected in local places." ${ }^{383}$ The office of the Akan chief has been challenged to respond to the demands of the changing time; for the principle of democracy and justice in today's globalized society "suggests that such ethnic enclaves or religious minorities must be countenanced, just as we leave the individual a sphere of privacy. In

\footnotetext{
${ }^{382}$ Ephraim-Donkor, African Spirituality: On Becoming Ancestor, 118. See also M. J. Field, Search For Security: An Ethno-Psychiatric Study Of Rural Ghana (New York: W. W. Norton and Company, Inc., 1970), 26.

${ }^{383}$ Merry, Human rights and Gender Violence, 4.
} 
the nation, there is no reason for conflicts between the larger society and these smaller ones, at least insofar as justice prevails." 384

The position of the chief challenges our entrenched understanding of democracy and human rights which are patterned in the Western way of thinking. To be able to understand this I offer another equally compelling concern about traditional and cultural protectionism issues that have universal human rights implications. The case of a twenty-eight year old woman who was subjected to severe manhandling at the orders of the paramount chief of Goaso gives a better understanding of this. ${ }^{385}$ The 2009 Country Reports for Human Rights Practices reported of a disturbing incident in the Brong Ahafo Region of Ghana where the paramount chief of the Goaso traditional area was alleged to have ordered the assault and manhandling of a twenty-eight year old woman for refusing to kneel before him when he (the chief) was passing as a sign of traditional obeisance accorded chiefs. In a more globalized and technologically explosive society, this incident attracted a lot of national and local media coverage and discussions but yielded no fruitful results. As is also expected in the context of a constitutionally governed society, the young woman made a formal complaint to the police. What is interesting is that the human rights report indicates that this poor woman and her mother were rather detained by the police.

This incident reveals a very serious and troubling human rights violation in the name of defending tradition. For some people, even if the media accounts and the human rights report were an overestimation of the reality, per the provisions of Act 759 of the Chieftaincy Act, 2008,

\footnotetext{
${ }^{384}$ William D. Keim, Ethics, Morality and International Affairs (Lanham, New York and Oxford: University Press of America, 2000), 233.

3852009 Human Rights Report: Ghana http://www.state.gov/g/drl/rls/hrrpt/2009/af/135956.htm. [Accessed November, 11, 2010].
} 
there is ample evidence to suggest that the young woman was subjected to customary sanctions for being in contempt of tradition. The said clause, inter alia, makes it clear that a person who

...(c) knowingly uses disrespectful or insulting language or insults a chief by word or conduct, (d) deliberately refuses to honour a call from a chief to attend to an issue, (e) refuses to undertake communal labour announced by a chief without reasonable cause, or (f) deliberately fails to follow the right procedures to destool a chief, commits an offence and is liable on summary conviction to a fine of not more than two hundred penalty units or to a term of imprisonment of not more than three months or to both and in the case of a continuing offence to a further fine of not more than twenty-five penalty units for each day on which the offence continues. ${ }^{386}$

The determination of whether or not the young woman's action constitutes an infringement of the first clause in particular is a legal and customary controversy of its own. However, for some pro-traditionalists, the young woman was not punished for practicing her faith or exercising her fundamental human rights. Rather, she was punished for practicing it in an unconventional manner, in a way that violated not only the tradition of the area but also the principles of this Act which forms a crucial part of the laws of the modern nation-state. No cost, they claim, can technically speaking, be awarded in her favor in the name of religious intolerance or chiefly abuse. In fact, this case presents a lot of challenges not only to the traditional and customary practices but also the democratic and legal system of the country. Brobbey, for example, has pointed out that in Ghana, "taboos are not contained in any written law as crimes. Penalties for their breach are not necessarily prescribed in written laws. ${ }^{\text {387 }}$ This assertion usually presents a dilemma for traditional societies within contemporary Ghanaian societies. Under what conditions then does the sanction become valid and acceptable in the context of the modern legal system?

The second most interesting aspect of this incident is that although the situation resulted in casting aspersions on the legal system of the country, a critical look at it also reveals that the

\footnotetext{
${ }^{386}$ See the article 63 (2) of Act 759 of the Chieftaincy Act, 2008.

387 S.A. Brobbey. The Laws of Chieftaincy in Ghana, (Accra: Advanced Legal Publications, 2008), p. 33,
} 
Akan chief is not only a powerful traditional leader, but he is also a very important actor of the politics of the nation-state in that the woman was detained by the police. The sanctity which hitherto surrounded the office of the chief, as has been discussed throughout this study, requires that whatever he does is right. That the police did not take any action on the complaint of the woman, but, in fact, detained her reveals the truth, to some extent, of the popular Akan maxim that "The King can do no wrong" ${ }^{388}$ which I would qualify by adding "as long as he acts $e x$ cathedra." His influence, particularly in areas distant from the reach of the central government, extends to the modern legal and security mechanism. This, and other similar events that have not to come to the public square due to widespread fear of undermining the integrity of the traditional state and the authority of the sacred chief, challenges the democratic system of the nation and also prompts us to think globally and to take alternative actions.

Admittedly, modern democratic institutions and globalization, as was seen in the previous chapter, have wounded the chieftaincy institution but have not totally crushed it. It is, therefore, incumbent on indigenous authorities to approach traditional and customary issues within the context of the larger religio-political perspective. Traditional societies and the chieftaincy institution cannot afford to live at the periphery of modern society, especially in matters related to the human rights of their (traditional states) members.

Earlier in chapter one, it was indicated that the acceptance of religious pluralism demands the toleration and approval of opposing views and beliefs in the society. The truth is that instead of uncompromising apologetic approach to enhance the image of the chieftaincy institution, a sympathetic understanding of such a culturally and religiously diverse society is a sure way of not only protecting the rights of citizens but also respecting tradition and custom. This is a winwin approach to enhancing and promoting religious human rights. The individual, by this

\footnotetext{
${ }^{388}$ R. S. Rattray, Ashanti Law and Constitution (Oxford: The Clarendon Press, 1929), 81.
} 
approach, becomes aware that though his or her rights as a free citizen cannot be curtailed unduly, it behooves him or her to respect the custom of the traditional area of residence as has been enshrined in the Constitution and the Chieftaincy Act (759) of 2008. In a society where the Constitution of the country takes precedence over all other laws it becomes extremely difficult for the chief to fully enjoy his power as preventative of the people.

\subsection{The Chief as Official Representatives of the Land?}

Another challenge that modernity has posed to traditional concept of power which has implication for human rights is in the area of the position of the chief as the custodian of the land. The case just discussed has revealed that with the democratization of tradition, the chief can no longer lay exclusive claim to being the sole custodian or representative of the ancestors. Especially in cases where there are clear evidence or enough basis for suspicion of abuse of chiefly power, the individual has been quite bold to openly challenge the position of the chief and the adjudicatory power associated with it. For example, in November 2011, the Ghanaian media reported that an Asona ${ }^{389}$ royal of Akyem Abuakwa, Odehye ${ }^{390}$ Kwame Boateng, accused the Okyehene Amoatia Ofori Panyin II, one of the influential and well respected chiefs in Ghana, of being involved in illegal mining in the Akyem area of the eastern region of the country. The said allegation, if indeed it was true, as was seen earlier in the case involving king Prempeh I and the colonial administrator, was a very serious offense not only against the ancestors but also a criminal offense against the laws of the modern nation-state. ${ }^{391}$

\footnotetext{
${ }^{389}$ Asona is one of the eight major clans within the Akan ethnic group.

${ }^{390}$ Odehye, in the local Akan language means royal. He is also believed to have been one of the candidates who were considered before the swearing in of the king.

${ }^{391}$ In 1989, the PDNC Law 218 made it illegal to operate the "galamsey business" without a license.
} 
Following the sitting of the elders of the Abuakwa traditional council, Odehye Boateng was found guilty of denigrating and desecrating the stool of the ancestors of the land. As a result, he was fined 72 sheep and 36 cartons of schnapps for the necessary ritual to be performed to appease the ancestors whose representative had been desecrated. The fine was to be paid within a week failure of which would lead to the accused being banished from the traditional area. The accused was found guilty of three counts of customary infractions. For his punishment he was fined 24 sheep and 12 crates of schnapps for each of the three counts. First, he was accused of failing to properly invoke the great oath of the Akyem state, Awukudae ne Kwanyarko, instead of the Memeneda ne Kwanyarko he recited. Second, contrary to the custom that require the accused to have hurriedly go to the chief's palace to announce to the chief and his elders the basis of his invocation, he failed to do this. Third, he has invoked what is said to be the Okyeman Ntam kese, the bonafide oath of the Okyenhene. The man, considering his claim to be true and seeing the sanctions to be unfair, openly challenged the king by invoking the Okyeman Ntam kese (the great reminiscential oath of Okyeman). ${ }^{392}$

What was interesting was that according to the report Odehye Boateng was particularly concerned that as a royal citizen of Kyebi, he strongly believed the ancestors of the land would not even forgive him (Boateng) if, despite his concerns, does not do anything about what he considered as a disgraceful act of galamsey. ${ }^{393}$ Thus, even if his action was a desecration of the chief, whose position would have previously been seen as sacred and unchallenged, it was done

\footnotetext{
392 The invocation of ntam kese (great reminiscential oath) of every traditional area is a serious act that must be responded to swiftly. It may only be invoked under extreme conditions. For a detailed understanding of the Akan reminiscential oath taboos, see Agyekum, "Ntam,"317-342; Rattray, Ashanti Law and Constitution; Busia, The Position of the Chief in the Modern Political System of Ashanti: A Study of the Influence of Contemporary Social Changes on Ashanti Political Institutions. (London: Frank Cass and Co. Ltd., 1968).

${ }^{393}$ In Ghana galamseys (also the activity itself) are people who manually engage in mining of natural resources mostly gold - independent of mining companies, usually by digging small workings (pits, tunnels and sluices). In 1989, the PDNC Law 218 made it illegal to operate the "galamsey business" without a license.
} 
in the interest of the sacred ancestors of the land whose interest was far more important than the chief's, at least in this context.

This case and similar others have proved that even in the face of modernity, there is a challenge to the chief's exclusive claim as the "official" representative of the ancestors of the land. First, although many of the masses cried foul about the hefty nature of the sanction imposed on the accused, there are enough bases to suggest that he was also aware of the consequences of coming face-to-face with the infraction of the custom of the land (even if he did not consider his action as a violation thereof). He dared the consequences and stood his ground.

Second, the case reveals the belief in traditionalism by both parties. The accused was also aware of his rights to seek legal redress at the law court as a citizen of the modern nation. The question that has been raised is why did he not then go to court but decided to settle the case by invoking the great oath of Okyeman? This is a question that needs to be taken into serious consideration in the context of what traditionalism represents in the modern nation state. Odehye Boateng, the accused, was emphatic that as a concerned royal of the land, he was also particularly worried about the desecration of ancestral legacy in the name of the king's personal benefit. Indeed, contrary to the popular response from most of the masses who contributed to the many radio discussions about the issue, the underlying assumption of the accused's statement gives the impression that he was not against the sanction and the heavy cost involved if his actions were to be wrong. He was reported as saying that the king must rather be fined to pay those items and these must rather be given to him (the accused) for exposing the wrong doings of the society which obviously aggrieve the ancestors of the land. Because traditional authorities have the power to determine the sanctions associated with customary violations, conflict usually 
ensues, as has been seen in the case discussed above, when the offending party disagrees with the decision of the traditional authorities and prefers to settle it in the law court.

\subsection{Issues of Concern and Policy Implication}

The discussion in this study has so far demonstrated that there is a significant risk in misappropriating the sacred metaphors of the chief and of neglecting them at the same time. In the discussion that follow I focus my attention on some interesting issues that need to be taken into account in appropriating the power of the chiefly office especially in national party politics.

\subsubsection{Constitutional Empowerment of the Chiefs}

Notwithstanding the various issues raised against the chieftaincy institution, the past two decades of Ghana's democratic "experimentation" have witnessed a growing concern and increasing respect for the institution especially, in matters related to the freedom of the said institution. Previous and current political regimes, during this period, for the most part, have attempted to act in accordance with the decisions, findings and recommendations of the chieftaincy institution. Such adherence is also supported by constitutional and other legal backings. In 2006, the J. A. Kufuor administration's attempt to promote, modernize and empower the institution, led to the formation of the Ministry of Chieftaincy and Cultural Affairs. The creation of the ministry, inter alia, was "part of the Public Services of Ghana to preserve, sustain and integrate the regal, traditional and cultural values and practices to accelerate wealth creation and harmony for total national development. ${ }^{394}$ As part of their mission, the ministry seeks to educate "chiefs on government policies for good governance, conflict resolutions among

394 See the webpage of the "Ministry Chieftaincy and Culture" at http://www.commonwealth-ofnations.org/Ghana/Ministry/Ministry_of_Chieftaincy_and_Culture/welcome. [accessed on Jan. 2012]. 
the various cultural groupings. Also by supporting the various chieftaincy and cultural institutions administratively, financially and review the various chieftaincy and cultural legal framework to conform to international best practices."395

The decision to review, repeal and amend the Chieftaincy Act of 1971, act 370, which gave way to the Act 759 of 2008 , was also a step in the right direction, especially in ensuring that frivolous chieftaincy disputes became a thing of the past. It was also meant to give the chief and his kingmakers more powers in dealing with the matters related to the cause of the chieftaincy institution without political interference. However, lack of a more consistent and efficient implementation of the said act has been a major drawback to the institution. This notwithstanding, there still remains a lot of concerns about cases of governmental interference and other court rulings that seek to undermine the independence of the chieftaincy institutions as well as the separation of powers that the act sought to achieve. As Brown-Mensa puts it:

The courtship ended with the statutory definition of a chief in the Chieftaincy Act, 1961. Today, the existence and the survival of the occupant of a stool or skin depends, in the final analysis, exclusively on the discretion of the Central Government, which yesterday was civilian, today is military, and tomorrow will be who knows what? The threat to the security of chieftaincy created by this new situation has been made evident by the series of recognitions and withdrawals of recognition by the government of enstooled chiefs, since the passing of the Chieftaincy Act in $1963 .{ }^{396}$

Thus, while successive governments deny any involvement in chieftaincy disputes, many chiefs have being arbitrarily enstooled and destooled through covert governmental support. Notwithstanding the numerous laws aimed at enhancing the institution, some legal provisions have turned to disable the chieftaincy institution, especially in matters related to their judicial roles.

\footnotetext{
${ }^{395}$ See the webpage of the Ministry Chieftaincy and Culture.

${ }^{396}$ Brown-Mensah, "Chiefs and the Law," 62.
} 
In matters of judicial powers of the chief, the empowerment of the chief as is found in the Chieftaincy Act 759 of 2008, will enhance quick and efficient discharge of justice. Traditionally, the swiftness with which cases are adjudicated at the chief's court saves a lot of human and logistical resources. With this in mind, I cannot but agree with the pro-chief campaigners that the abolition of the institution is as serious political suicide as any group of people can imagine. ${ }^{397}$ The said move to abolish it, in the present generation and perhaps generations that immediately follow, will always be impossible. As Supreme Court Justice, S. A. Brobbey, has observed, part of the impossibility of the move is because almost every indigenous Ghanaian is a subject to one traditional state or the other and is unwilling to compromise even if there is any disaffection in the institution. It is in this light that the call for the integration of the chieftaincy institution into the current political system as a form of surrogate political alternative must be taken into serious consideration.

Rather than entirely abolishing the institution as has been the proposal of some anti-chief proponents, ${ }^{398}$ there is the need to promote the facelift the institution is undergoing. The chieftaincy institution is not only an ancestral legacy but also an enduring national relic whose value cannot be left to demise. As has been argued, the institution is significant not only for traditionalists but also for national unity and development as leaders of the nation-state (the

\footnotetext{
${ }^{397}$ S.A. Brobbey, Laws of Chieftaincy in Ghana, 5.

${ }^{398}$ For example, following the impasse between the Okyehene and Odehye Boateng, Dr. Michael J.K. Bokor, an Assistant Professor of English at Long Island University, Brooklyn, argued that the internal weaknesses of the chieftaincy institution (which he branded the dying donkey) makes it unattractive and must be abolished. See Dr. Michael J. K. Bokor, "When 72 sheep bleat in the Ofori Panin Palace..." (November 29, 2011) http://opinion.myjoyonline.com/pages/feature/201111/77222.php. Similar attempts have also been made prior to this. In 2008, for example, the then minister of Chieftaincy and Culture, S.K. Boafo, called for a national debate on the need to maintain the chieftaincy institution of scrape it which received a lot of controversial responses. See Kofi Akosah-Sarpong, Sampson Boafo's Chieftaincy Confusion," The Statesman, January 10, 2008.
} 
politicians) draw their support mainly from the chiefs. Such a facelift can happen in a number of ways.

\subsubsection{Sale of Land Reforms}

First, an important means of modernizing the institution is taking a second look at some of the exclusive chiefly rights that would not, in any way, offend the ancestors of the land. Admittedly, some of the functions and rights of the chief cannot be taken away from them without affecting the core essence of the office. For some time now, some of the rights of the chief have been a major source of concern with some making a lot o proposal to put a check on it. It is for this reason that I agree with recommendations that call for the revamping of the land tenure system. I agree with Dr. Vladmir Antwi-Danso, a Senior Fellow at the Legon Center for International Affairs, that doing so has the potential of making sure that no chief has the exclusive right of selling stool land that has been bequeathed to their care. ${ }^{399}$

Over the years, the chieftaincy institution has come under intense pressure from citizens who feel their rights have been curtailed especially in matters related to the sale of stool lands. As was argued earlier in this chapter, the sacredness of the institution has come under intense confrontation and disdain. Some of these confrontations become abusive and, as was the case involving the Okyehene and Odehye Boateng reviewed earlier in this chapter, in some extreme cases, it becomes violent and bloody. To avert this, authorized governmental agencies, in collaboration with the traditional councils, must be mandated to take over the task of selling such lands. This has a dual purpose. First, the possibility of using the monies from the sale of the land for the benefit of the whole community is, to some greater measure, assured. Proceeds from such

\footnotetext{
${ }^{399}$ Dzifa Emma Tetteh, “Ghana Needs To Modernize Its Chieftaincy System," The Ghanaian Times (Accra, June 24, 2010).
} 
sales must be kept in an account designated for such purposes. For purposes of transparency, both parties (governmental agencies and the chiefs) must be signatories to such an account so that one party cannot abuse the monies accrued from the sale of the land.

Second, the said move has the potential of limiting the occasional scuffles that ensue as a result of the sale and resale of lands without proper documentation. Of course, the obvious difficulty of this proposal is evident enough. Especially in a society where the land does not exclusively belong to the individual but rather is considered as an ancestral legacy, resistance to such a move will always be expected. ${ }^{400}$ In the light of this, proper consultation with the parties involved, due diligence in its implementation and proper education of the people on the contemporary necessity of such a reform are important in averting some of these problems.

\subsubsection{Program of Succession Plan}

In 2008, Ghanaians hailed the passage into law the Chieftaincy Act, Act 759 which replaced the old one passed in 1971. Part of the joy was that the new act gave hope especially in dealing with cases of needless chieftaincy disputes involving various claimants to the stool or skin of the area. Again, it is important to note that the history of the chieftaincy institution in Ghana is filled with succession disputes which have been a major source of worry in most traditional societies. Indeed, such is the major argument that most anti-chief proponents base their claim on. For such proponents, the amount of monies spent by the central government to ensure peace in such warring traditional areas is quite worrisome and can be channeled into other areas of the society if the institution is scrapped. It is believed that scrapping it is not the solution to the problem. What the institution needs is modernization. As article 1 (b) of the Chieftaincy

\footnotetext{
${ }^{400}$ Janine M. Ubink and Kojo S. Amanor, eds., Contesting Land and Custom in Ghana: State, Chief and the Citizen (Leiden: Leiden University Press, 2008).
} 
Act 2008, Act 759 enjoins the National House of Chief to "undertake the progressive study, interpretation and codification of the customary law with a view to evolving, in appropriate cases, a unified system of rules of customary law, and compiling the customary laws and lines of succession applicable to each stool or skin." This was meant to limit the number of cases, if not eliminate it completely.

It must also be said that the establishment of the Ministry of Chieftaincy and Culture, mentioned earlier, is a step in the right direction. The ministry must go beyond its objective of, among others, monitoring and evaluating activities of the chieftaincy and culture sectors. The ministry and the National House of Chiefs in particular must have as part of their comprehensive plans, a program to draw up succession plans. It must, as a matter of pragmatic importance, also have a program of educating the chief on the need to draw up successive plans that seek to take into consideration historical and long-term succession. Such succession planning has been successful in areas such as Japan, England and elsewhere. In this case, the heirs and their various royal families become apparent not only to kingmakers but also to the general public. This also limits the numerous bribery and corruption allegations that characterize the election of successors to the seat of the ancestors.

\subsubsection{Education of Chiefs}

Closely related to the succession plan is intensive education of the would-be chief especially in matters related to statecraft and modern governance. The chieftaincy institution, according to Brown-Mensah, is "an institution which implies a network of personal relationships and problems, the satisfactory regulation of which can perhaps better be found in the use of local administrators who are qualified in traditional affair" ${ }^{401}$ It is for this reason that the call for the

\footnotetext{
${ }^{401}$ Brown-Mensah, "Chiefs and the Law," 62.
} 
education of the chief is an appropriate one. Once there is a clear successor, the next most important task is the education of the heir. Throughout this work, it has been indicated that the chieftaincy institution and the life of the chief are shaped by a host of historical and ideological foundations which are based on the sacrality and its associated taboos. A breach of these taboos is enough basis for destooling the offending chief. As such, traditionally, after being nominated as a chief, most Akan societies present their candidate with the opportunity to be schooled in the art of statecraft as well as other customary and traditional practices especially regarding chieftaincy affairs. The candidate is usually put in solitary confinement where he is given tutorials on traditional good governance and ritual performance. This is important to learn how to successfully lead the people. While these trainings are highly important for the proper conduct of the chief, it is believed that giving them at the early stages of the life of the candidate goes a long way to benefit not only the would-be chief but the larger society.

Admittedly, some societies go to the extent of sending such heirs to other traditional states for further training. Historically, we hear of prominent Asante kings being sent to other traditional states for further customary training, among others. It is on records, for example, that Otumfuo Osei Tutu I was sent to the palace of the Omanhene of Denkyira for training. Similarly, the present Asantehene, Otumfuo Osei Tutu II is also known to have received his training from the court of Omanhene of Sehwi Wiaso, under Nana Kwadwo Aduhene's kingship. It is therefore incumbent that future chiefs are given the necessary level of training required of a modern chief.

It is also incumbent that there exists an establishment of research centers. As BrownMensah observes "one wonders whether the time is not long overdue for the establishment of a 
well-defined permanent research centre on an inter-disciplinary basis in Ghana, in place of Commissions of Enquiry with their attendant drain on an already leaking national economy." ${ }^{402}$

\subsubsection{Progressive Study of Chieftaincy Affairs}

A very fascinating ambivalence of the Akan chieftaincy institution which also challenges both local and international legal systems is its hereditary nature. Ascendance to the stool of the ancestors is not dependent on how well one is schooled in, for example, the early Greek political philosophy or how flawless one is able to speak the Queen's language - the language of colonialism, neither does it depend on how articulate one is in matters of global economic and financial policies. While contemporary changes have made these qualities necessary, the tradition regarding the qualification of an Akan does not put emphasis on this. What this means is that while most societies may opt for a leader who is well versed in the demands of the interplay between traditionalism and modernity, the rule that guides the ascension to the stool of the ancestors remains essentially the same.

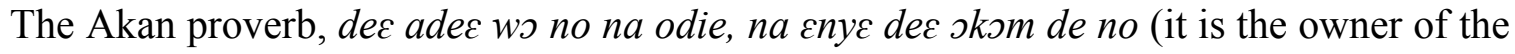
food that eats it, and not the hungry) tells it all. Becoming a chief is, first and foremost, about having royal blood in you. All other qualities are secondary. It is for this and other similar reasons that the Asantehene, the Otumfour Osei Tutu the second in 2008 cautioned against, and indeed banned the use of academic and "big" title in his domain. According the Otumfour, the chiefly accolade, Nana, is sacred and more valuable than any foreign name or culture. He also cautioned against his chiefs using suits to attend official function, an act he described as having the potential of bringing the institution into disrepute. Big titles, he said, do not make one a chief good but rather a good chief depends on how well the person has been able to live up to

\footnotetext{
${ }^{402}$ Brown-Mensah, "Chiefs and the Law," 60.
} 
traditional expectations of the society; for the time has come for the chief to make the institution look more traditional. What was quite fascinating about the Otumfour's observation was that the changing society demands that chief must be equipped enough to fight the modern enemies of poverty, ignorance, disease and conflict etc, the failure of which a chief will not be fit to be regarded as such. Thus, modernity challenges traditionalism to reshape itself to suit the demands of the time.

Of yet another difficulty inherent in this tradition is in cases where there are two legible candidates, one being an "obvious" heir but uneducated or not so well educated, and the other being an auxiliary heir but highly educated. Contemporary changes in the society have called for the choice of a candidate who, as has been indicated, will be able to fight for the development of his people at the national level. This has made education an important qualification to the stool in contemporary times. Under such circumstances, contemporary kingmakers (even if in rare cases) rally behind the educated candidate. This usually brings disaffection, revolt and in most cases, lifetime rivalry and embitterment in the minds and hearts of the "rejected" candidate and his supporters. However, it must be said that whoever tradition or modernity demands that he should be enstooled, there is the need to be always reminded of the changing demands of the society.

The chieftaincy institution has, over the years, availed itself to the challenges that the demands of the rapidly changing society puts on it. For some time now, the House of Chiefs (national or regional) in conjunction with the Ministry of Chieftaincy and Cultural Affairs and other state and non-state actors such as the Konrad-Adenauer Foundation $(\mathrm{KAF})^{403}$ has undertake some sensitization workshop aimed particularly to update the chief of the some changes in the

\footnotetext{
${ }^{403} \mathrm{KAF}$ is a think-tank and consulting agency, a political foundation, dedicated to offering extensive range of civic education conferences and events. In Ghana, the foundation has been particularly involved in organizing workshops and seminars for the chiefs.
} 
society as well as modern forms of governance. ${ }^{404}$ These workshops are meant to also find new ways of integrating the traditional political institutions into the decentralization process of the new nation-state. They are also aimed at innovative ways of reforming the office of the chief to make it attractive to the members of the modern society. This is a welcoming idea for purposes of the transformation of the institution. Side by side with the education of chief and heirs on traditional statecraft is constant education modern system of governance. Although the Ministry of Chieftaincy and Culture has in its policy the education of "chiefs on government policies for good governance, conflict resolutions among the various cultural groupings, ${ }^{, 405}$ such dream is far from its realization. It is on the basis of this that the challenge is thrown to the ministry to rise up to the need to educate the chief.

\subsection{Conclusion}

The discussion in this chapter has proved that the indigenous constituencies of the chief are under the compelling influence of democratic principles and international human rights laws. The forces of change (modernization, globalization, religious pluralism, increased awareness of international human rights laws, among others) are irreversibly persuasive and inevitable. These forces have challenged the exclusive rights of the chief as the custodian of the society. This in turn has challenged to chieftaincy institution to be more open to democracy than it used to be traditionally. Traditional leaders, therefore, have no compelling alternative other than transforming the institution to reflect the changes that these forces demand.

\footnotetext{
${ }^{404}$ The Chieftaincy Act (759 of 2008) quoted earlier, for example, recommends that the National House of Chiefs undertake a progressive study of the custom of the traditional area.

${ }^{405}$ See the webpage of the Ministry Chieftaincy and Culture.
} 


\section{CHAPTER VIII: SUMMARY, SIGNIFICANCE AND CONCLUSION}

\subsection{Summary}

The study has attempted to enhance the positive elements of the Akan chiefly metaphors and how these have been challenged since colonialism up to the present time. That notwithstanding, care has been taken not to canonize this ancestral tradition and legacy ${ }^{406}$ as the sine qua non of the modern democratic dispensation. This study has given an exploration of the context of the struggle of the Akan chieftaincy institution as indigenous political system. The first four chapters of the study were devoted to understanding the context of this institution, the ideological and practical basis upon which the sacredness of the chief's office has been based. It was established the pre-colonial Akan chief was the single most important and influential political figure of his territory. The ideological basis of his office is a religious one. As an intermediary between the living and the ancestors, the chief's office is a held in esteem. In chapter five, it was indicated that with the coming of the colonialism and guest religions such as Christianity, resistance and nonconformity became an important hallmark of the Akan traditional society. The prevailing values and norms of the society came to be undermined and neglected by even minority beliefs and practices.

The discussion in chapter six took the challenge further and observed that modernity and globalization, which followed colonialism and European Christianity, also presented the office of the chief with several series of alternative views of not only viewing himself, but also how to deal with his people. Most of the responses from the chief usually have implications for the human rights of his subject. Reformulation of the sacred metaphors of the Akan chief as discussed in chapter seven therefore becomes a necessary call for a newer understanding of the

\footnotetext{
${ }^{406}$ Be'ne'zet Bujo, Foundations of An African Ethics: Beyond the Universal Claims of Western Understanding, trans. Brian McNeil (New York: The Crossroad Publishing Company, 2001), 131.
} 
hitherto sacrosanct nature of the Akan chief. The chapter called for a (re)interpretation of the chieftaincy institution - one that acknowledges the concern and rights of its citizens. It proposed an avenue for understanding any injustice suffered in the name of the institution. In order to preserve this national legacy while respecting the rights of citizens, I proposed an opportunity that is given to every member of the society to freely (without any customary limitations) challenge, express opinion, criticize, disagree and present an alternative reality in the society which at the same time respecting this institution. In this chapter I conclude the whole exploration by first taking the reader through a synopsis of the various concepts that came up. I begin by giving a summary of the whole discussion and also indicate the significance of undertaking this study. The next part of the discussion takes a look at some of the challenges that came up in the course of the study and what needs to be done. I conclude the whole discussion with a note of observation made throughout this exploration.

\subsection{Significance of the Study}

This research is significant for three reasons. First, it has sought to fill in the academic gap that has been created on the issue of the sacred position of the chief. The role of the chief as a unifier, a father, embodiment and repository of tradition, etc., was well documented in several academic works during the colonial era. ${ }^{407}$ With the changing dynamics of the Akan traditional society, especially in the decades immediately after independence, post-independence scholarship was focused on how the chieftaincy institution could be incorporated into the modern political system. ${ }^{408}$ The topic continued to be investigated to-date. Previous studies focused

\footnotetext{
${ }^{407}$ Rattray, Ashanti Law and Constitution.

${ }^{408}$ Busia, The Position of the Chief. However, I must admit that Abamfo Atiemo sets the pace when addressed the interface between international human rights, religious pluralism and international human rights and its implication for the future of the Ghanaian chieftaincy institution. See Atiemo, "International Human Rights."
} 
mainly on the indispensability of the chieftaincy institution in matters related to democracy and development. ${ }^{409}$ In all these works, no special intellectual attention was paid to the challenges associated with the sacred position of the chief especially on issues of the full enjoyment of the human rights of the chief's subjects in contemporary Ghanaian society.

Although much has been written about the position of the Akan chief from pre-colonial times to the present era, the human rights implications of the sacredness associated with his office has been one of the most under-explored areas in scholarly studies. Part of the existence of this gap stemmed from what most scholars refer to as the delicate nature of the chieftaincy institution. In most cases, the office of the chief has challenged not only discourse on its transformation but also, legal decisions concerning it. While agreeing that the chieftaincy institution is a delicate one, the major reason for the silence on this issue, among others, has been academics concern to preserve scholarly and social respectability. Most scholars do not want to come into open or silent confrontation with either the chief or their subjects. Therefore, conventional academic discussions usually focus on the positive resources of the chieftaincy institution and avoid the "forbidden" aspect of the institution - the hegemonic control and the abuses inherent in the institution. ${ }^{410}$

Social commentators and human rights activists working towards peaceful integration and modification of the chieftaincy institution have also woefully under-acknowledged the

\footnotetext{
${ }^{409}$ Irene K. Odotei and Albert K. Awedoba, Chieftaincy in Ghana: Culture, Governance and Development (SubSaharan Pub \& Traders, 2006).

${ }^{410}$ For example, in a very popular traditional hi-life song $\mathrm{Ka} \mathrm{NaWu}$ ("Say It and Die", i.e be bold and say the truth) composed by the ace musician, Asiebu Amanfi, the singer recounted the obvious dangers of pointing out the wrongs of the ancestors. According to the lyrics of the songs, doing so incurs the wrath of the ancestors and would lead one to be invited to the court of the ancestors to answer charges of impertinence. Meanwhile the court of the ancestors is the land where no one has ever gone and returned alive. Though most observers think that the song was a political parody intended to ridicule the military regime of the time, Amanfi uses the court of the ancestors as his symbolic representation due to the apparent culture of silence in the "court of ancestors."
} 
problematic nature of the sacred position of the chief in the face of changing society. In most cases, they attempt to explore the dangers inherent in the chieftaincy institution especially in terms of chieftaincy disputes, property rights and the conflicts that result from land tenure system, among others. As a result, what these activists attempt to do was mainly to agree with the framers of the 1992 Constitution's call to action - a reform or abolition of some of what it refers to as outmoded practices associated with the chieftaincy institution. Indeed, most popular views support these actions. The major challenge confronting the implementation of such proposals has been how and when. Part of the problem has been lack of intellectual will and courage to confront this issue.

The study has demonstrated that people who openly raise this issue have often risk the tendency of being branded as insolent and disrespectful to traditional authorities and practices. ${ }^{411}$ Those who dare to propose reforms also do so without considering the probable implications of such reforms. This has created a very serious popular and intellectual oversight of an important dimension of chieftaincy institutions - what the chief represents and its implication for citizen's religious human rights. This study, therefore, sought to "fill in the gap." It sought to depart from all the normative approaches indicated and rather focused on innovative models of integrating tradition and modernity into contemporary human rights discourse.

Second, the study has also sought to challenge the popular social consciousness regarding the position of the chief. It has demonstrated that contrary to the popular assumption that indigenous political institutions have lost control, in communities far from the sight of and interaction with the central government and even in major urban areas, the indigenous political institutions still maintain their sacred chiefly authority. Using the Akan chieftaincy institution as

\footnotetext{
${ }^{411}$ For example, the social commentator, Kwesi Pratt, has on several occasions come under verbal and physical threat of life for openly confronting traditional authorities and practices.
} 
a case study, the research demonstrated that the perception that the office of the chief which is tied up with religion has lost its control in the contemporary era, is wholly mistaken. The study rather argued that the numerous contemporary tensions that emerge in the traditional societies are a new expression of challenges associated with the encounter with other cultures as a result of modernity and globalization in particular which are expressed in conflicts and disputes in the society.

Third, and finally, this study has proved to be practically relevant especially for policy making. Although several attempts have been made in trying to find all inclusive peaceful solutions to conflicts resulting from chieftaincy disputes, these approaches usually do not yield the desired results. Part of the problem is lack of appropriate theoretical basis upon which the recommendations are built. Throughout this study, it was argued that a much broader approach to addressing the issue must be adopted. The cases used in this study proved that scholars and policymakers usually overlook important determinants of conflict. The study proposed to use a win-win approach that seeks to find a common ground for the modification of some aspects of the chieftaincy institution while at the same time suggesting ways of preserving it as a national legacy.

\subsection{Limitations and Suggestions for Future Research}

Through this study, it became clear that the disappointment of the nationalist leaders to promote and fulfill pre-independence expectations of their new members - who had hitherto been the faithful subjects of the chief - has been blamed on the heightened tribal conflict and solidarity in the continent. For, indeed, it is ironic to see the ethno-tribal people who had overwhelmingly supported the nationalist idea (at least in terms of the support for freedom) to only later turn their back against these nationalist leaders in favor of the chief. Many of the 
masses did not initially foresee any strong implications of nationhood during the early fight for independence. If they were any implications counted, they were those "linked to the slogan of nationalism to a removal of the colonial incubus, ${ }^{, 412}$ of liberation from British imperialist regime. However, the displeasure found in post-independence leaders of the nation-state has made the office of the chief doubly useful in the society.

For one thing, owing to the inability to provide the needs of the people, the masses often rely on the chief for the provision of their basic necessities of the community and consolation in life. This indeed brings into action the literary fatherly role of the chief as discussed earlier. In most cases, the chief, seeing himself as the father, treats the subjects as his own children whose rights must be determined by the father. Most of the actions against the subjects turn to limit their rights. For another thing, the helplessness of the situation also leads the masses to see the politician with suspect. He has disappointed them and is (or must) not be trusted any longer. Conscious of the demise of his position, the politician allies himself with the chief to rally support in his (the chief's) territory. This, again, makes the influence of the chief vital. Given the opportunity to compete with the politician in the national politics, the chances are that, despite the abuses inherent in the office of the chief, due to his close contact with the people, the chief will probably have more support than the "trained" politician.

This and other similarly compelling factors have made the limitation of the office of the chief to custom specific matters possible. The official reason usually given is that the institution of the chieftaincy is a noble one and must therefore not be dragged into the mud with constant insubordination and confrontation as is usually found in party politics. The idea, among other things, was to make sure that the chief always maintain his dignity and remain a unifying factor

\footnotetext{
412 Basil Davidson, The Black Man's Burden: Africa and the Curse of the Nation-State (New York: Times Books, 1992), 164.
} 
of his community. To make this reason official, Article 276 (1) of the 1992 Constitution recommends that: "A chief shall not take part in active party politics; and any chief wishing to do so and seeking election to Parliament shall abdicate his stool or skin."

Ironically, though the chief is prevented from actively doing party politics, he is the central point of contact for the very same politicians who seek to prevent him (the chief) from entering into party politics. As has already been shown, a cursory look at the daily activities of the people demonstrates that the influence of the indigenous political authorities extends far beyond the control of the leaders of the nation-state. Given this background, the question that came out in this study, but was not dealt with, for lack of space and time, was While the 1992 Constitution prevents the chiefs from any active politics, will a political party ever win any election without the influence of the ethno-tribal leaders? Conscious of the fact that any in-depth analysis of this problematic issue has the potential of distracting the focus of the research; it was laid to rest with the view to making it an entirely new area for further research. Future researchers interested in predicting the consequences of the interface between the Akan chieftaincy institution and the central government can take up this challenge. This is a problematic and significant area that evokes a lot of concerns especially in a traditional society with fast growing awareness of western influenced modes of governance.

\subsection{Conclusion}

This research has demonstrated that alternative religious, socio-economic, political, etc, views of reality have presented the Akan, especially the youth, with a sense of desacralization of the chiefly office and authority. The research gave a detailed analysis of the historical and ideological foundation of the sacredness associated with the Akan chieftaincy institution. It was observed that the sacred metaphors of the Akan chief have, through time and space, been 
challenged on several grounds: through the impact of colonialism, western civilization especially education, Christianity, neo-Marxists political ideologies and international human rights systems. These represent some challenges in the traditional societies, especially in places where the control of the chief is still strong. Under such conditions, conflict and violence are the ultimate outcome. It was noted that traditionally, one who decides to resist the sacred also prepares to fleet from reality. The sacred, the research argued, provides the basis for the solidarity of the members of the society. Thus, any attempt to escape from the demands of the sacred is also a decision to flee from its reality.

In the context of the Akan chieftaincy institution, the crossing point between the sacred and abuse of rights is usually within what Antonio Gramsci referred to as hegemony of the ruling class. The Akan traditional system of governance based on sacralized sources of legitimacy has today been frustrated by contemporary human rights laws. The result of this research has shown that the chief is afraid that if the sacred ancestors are challenged, the foundation of his legitimacy as overlord of the traditional state will be shaken. Ignoring the ancestors of the land, it was indicated, has a host of challenges for the traditional state and implications for the religious human rights of the citizens of the country which form part of the larger international human rights regimes which every globalized society has been challenged to respond to. 
Bibliography

Achebe, Chinua. Things Fall Apart. New York: Fawcett Crest, 1989.

Adams, Laura L. "Globalization of Culture and the Arts." Sociology Compass 1, no. 1 (2007): $127-142$.

Agyekum, Kofi. "Ntam 'Reminiscential Oath' Taboo in Akan.” Languages in Society 33, no. 3 (May 2004): 317-342.

- "The Sociolinguistic of Akan Personal Names." Nordic Journal of African Studies 15, no. 2 (2006): 206-235.

AkanBa. Revelation: The Movement from Kanaan to Ghana. Central Milton Keynes: AuthorHouse, 2010.

Akrong, Abraham. "Religion and Traditional Leadership in Ghana." In Chieftaincy in Ghana: Culture, Governance and Development, edited by Irene K. Odotei and Albert K. Awedoba. Accra: Sub-Saharan Publishers, 2006.

Akyeampong, Emmanuel. "Christianity, Modernity and the Weight of Tradition in the Life of 'Asantehene' Agyeman Prempeh I, C. 1888-1931." Africa: Journal of the International African Institute, 69, no. 2 (1999): 279-311.

An-Na'im, Abdullahi A. "The Politics of Religion and the Morality of Globalization." In Religion in Global Civil Society, edited by Peter Juergensemyer. Oxford and New York: Oxford University Press, 2005.

An-Na'im, Abdullahi Ahmed. "Introduction: Competing Claims to Religious Freedom and Communal Self-Determination in Africa." In Proselytisation and Communal SelfDetermination in Africa,. Maryknoll and New York: Orbis Books, 1999.

Anyinam, Charles. "Ethnomedicine, Sacred Spaces, Ecosystem Preservation and Conservation in Africa." In Sacred Spaces and Public Quarrels: African Cultural and Economic Landscapes. Trenton and Asmara: Africa World Press, Inc., 1999.

Apter, David E. Ghana in Transition. Princeton \& New Jersey: Princeton University Press, 1972.

Arhin Brempong. "The Role of Nana Yaa Asantewaa in the 1900 Asante War of Resistance." Le Griot VIII (2000): 97-110.

Arnett, J.J. "Psychology of Globalization.” American Psychologist 57, no. 10 (2002): 774-83.

Ashanti. Colonial Annual Report. Great Britain: House of Commons, March 23, 1906.

Atiemo, Abamfo Ofori. "International Human Rights, Religious Pluralism and the Future of Chieftaincy in Ghana." Exchange 35, no. 4 (2006): 360-382. 
Bari, Osman B. A Comparative History of Muslims and Religion in Ghana. Vol. 1. Accra: Dezine Focus, 2009.

Bauman, Whitney. Theology, Creation, and Environmental Ethics: From Creatio Ex Nihilo to Terra Nullius. New York: Routledge, 2009.

Blocher, Joseph. "Building on Custom: Land Tenure Policy and Economic Development in Ghana." Yale Human Rights and Development Law Journal 9 (2006): 166-202.

Boafo-Arthur, K. "Chieftaincy and Politics in Ghana Since 1982." West Africa Review 3, no. 1 (2001).

Boahen, A. Adu. Yaa Asantewaa and the Asante-British War of 1900-1. Edited by Emmanuel Akyeampong. James Currey, 2003.

Brempong, Arhin. Transformations in the Traditional Rule in Ghana (1951-1996). 1st ed. Sedco Pub Ltd, 2001.

Brempong, Owusu. "Chieftaincy and Traditional Taboos: An Empirical Approach." In Chieftaincy in Ghana: Culture, Governance and Development, edited by Irene K. Odotei and Albert K. Awedoba. Accra: Sub-Saharan Publishers, 2006.

Brobbey, S. A. The Law of Chieftaincy in Ghana: Incorporating Customary Arbitration, Contempt of Court, Judicial Review. Accra: Advanced Legal Publications, 2008.

Brydon, Lynne. "Women Chiefs and Power in the Volta Region of Ghana." Journal of Legal Pluralism and Unofficial Law, no. 37-38 (1996): 227-247.

Bujo, Be'ne'zet. Foundations of An African Ethics: Beyond the Universal Claims of Western Understanding. Translated by Brian McNeil. New York: The Crossroad Publishing Company, 2001.

Busia, K. A. "The Ashanti of the Gold Coast." In African Worlds: Studies in the Cosmological Ideas and Social Values of African Peoples, edited by Daryll Forde. Reprint. MunsterHamburg: International African Institute, 1999.

- The Position of the Chief in the Modern Political System of Ashanti: A Study of the Influence of Contemporary Social Changes on Ashanti Political Institutions. London: Frank Cass and Co. Ltd., 1968.

Byers, Dohrman W. "The Morality of Human Rights: A Secular Ground" 26, no. 1. Journal of Law and Religion (2011 2010): 2-41.

Casely, Hayford J. E. The Truth About the West African Land Question. New York: Negro Universities Press, 1969.

Dadosky, John D. The Structure of Religious Knowing: Encountering the Sacred in Eliade and Lonergan. Albany: State Univ of New York Press, 2004. 
Danquah, J. B. The Akim Abuakwa Handbook. London: Foster Groom \& Co.,, 1928.

Danquah, J.B. The Akan Doctrine of God: A Fragment of Gold Coast Ethics and Religion. 2nd ed. London and New York: Routledge, 1968.

Davidson, Basil. A History of West Africa 1000-1800. New Ed. London: Longman Group Ltd, 1977.

- The Black Man's Burden: Africa and the Curse of the Nation-State. New York: Times Books, 1992.

Davis, Stephen. Reggae Bloodlines: In Search of the Music and Culture in Jamaica. New York: De Capo Press, 1992.

Dawson, Christopher. Religion and Culture. First ed. New York: Sheed \& Ward, 1948.

Dennis M. Warren. A Re-appraisal of Mrs. Eva Meyerowitz's Work on the Brong. Research Reports, n.d.

Dennis, Warren M. “Bono Art Shrine.” African Arts 9, no. 2 (1976): 28-34.

—. "Bono Royal Regalia." African Arts 8, no. 2 (1975): 16-21.

Eide, Asbjorn. "Dynamics of Human Rights and the Role of the Educator." In Frontiers of Human Rights Education, edited by Asbjorn Eide and Marek Thee. New York: Columbia University Press, 1983.

Eliade, Merci, and Lawrence E. Sullivan. "Hierophany." In Encyclopedia of Religion. Vol. 6. New York: Macmillan, 1987.

Eliade, Mircea. Patterns in Comparative Religion. Translated by Rosemary Sheed. New York: Meridian Books, 1949.

- The Sacred and The Profane: The Nature of Religion. Translated by William R. Trask. Orlando: Harcourt, Inc., 1957.

Ellis, A. B. The Tshi-Speaking Peoples of Gold Coast of West Africa. Oosterhout N.B: Anthropological Publications, 1970.

Ephraim-Donkor, Anthony. African Spirituality: On Becoming Ancestor. Trenton \& Asmara:: African World Press, 1997.

Ezema, Ifeanyi J. "Globalisation, Information Revolution and Cultural Imperialism in Africa." Information, Society and Justice 3, no. 1. 11-22 (January 2010).

Femia, Joseph V. Gramsci's Political Thought: Hegemony, Consciousness, and the Revolutionary Process. Oxford: Clarendon Press, 1981. 
Field, M. J. Search For Security: An Ethno-Psychiatric Study Of Rural Ghana. New York: W. W. Norton and Company, Inc., 1970.

Fiona Araba Gibson. "The Akan Queen Mothers in Ghana and the Implications of Covert Gynocracy". PhD Thesis, unpublished: University of Wales, 2010.

Foladare, Irving S. "A Clarification of 'Ascribed Status' and 'Achieved Status'." The Sociological Quarterly 10, no. 1 (Winter 1969): 53-61.

Fortes, Meyer. Kinship and the Social Order: The Legacy of Lewis Henry Morgan. Chicago: Aldine Publishing Company, 1963.

Geertz, Clifford. The Interpretation of Cultures. New York: Basic Books, 1973.

Geest, Sjaak van der. "Opanyin: The Ideal of Elder in the Akan Culture of Ghana." Canadian Journal of African Studies 32, no. 3 (1998): 449-493.

“Ghana’s Leap from Stone Age to Eager New Nationhood.” Life 48, no. 2 (18, 1960): 78-91.

Ghanea, Nazila. "Religion, Equality, and Non-Discrimination." In Religion and Human Rights: An Introduction. Oxford: Oxford University Press, 2012.

Giddens, Anthony. A Contemporary Critique of Historical Materialism. Vol. 1. Berkeley and Los Angeles: University of California Press, 1981.

- "From the Consequences of Modernity." In Colonial Discourse and Post-Colonial Theory: A Reader, edited by Patrick Williams and Laura Chrisman. New York: Columbia University Press, 1994.

- Modernity and Self-identity: Self and Society in the Late Modern Age. Cambridge, England: Polity Press, 1991.

Gilbert, Michelle. "The Christian Executioner: Christianity and Chieftaincy as Rivals." Journal of Religion in Africa 25, no. Fasc. 4 (1995): 347-386.

Gramsci, Antonio. Selections from the Prison Notebooks of Antonio Gramsci. Translated by Quintin Hoare and Geoffrey Nowell Smith. London: Lawrence and Wishart, 1971.

Gyekye, Kwame. Tradition and Modernity: Philosophical Reflections on the African Experience. Oxford: Oxford University Press, 1997.

Hayford, J.E. Casely. The Truth About the West African Land Question. London, 1913.

Heusch, Luc de. "Forms of Sacralized Power in Africa." In The Character of Kingship, edited by Declan Quigley. Oxford and New York: Berg Publishers, 2005.

Horton, Robin. "African Conversion." Africa: Journal of the International African Institute, XLI, no. 2 (March 1971): 85-108. 
I.F. Joe Awuah Jnr. "I Will Kidnap Techiman Chief: Otumfour Warns Mills.” Daily Guide,, February 16, 2010.

Inglehart, Ronald, and Christian Welzel. Modernization, Cultural Change, and Democracy: The Human Development Sequence. New York: Cambridge University Press, 2005.

Janine M. Ubink, and Kojo S. Amanor, eds. Contesting Land and Custom in Ghana: State, Chief and the Citizen. Leiden: Leiden University Press, 2008.

Kimble, David. A Political History of Ghana: The Rise of Gold Coast Nationalism 1850-1928. Oxford: The Clarendon Press, 1963.

Kludje, A Kodjo Paaku. Chieftaincy in Ghana. Lanham: Austin \& Winfiled, Publishers, 2000.

Knierzinger, Johannes. "Chieftaincy and Development in Ghana: From Political Intermediaries to Neotraditional Development Brokers". Working Paper, Department of Anthropology and African Studies, n.d.

Kwame Nkrumah. Ghana: The Autobiography of Kwame Nkrumah. New York: International Publishers, 1957.

Laitin, David D. Hegemony and Culture: Politics and Religious Change Among the Yoruba. Chicago and London: The University of Chicago Press, 1986.

Lange, Dierk. Africa-Centred and Canaanite-Israelite Perspectives. Dettelbach: Verlag J.H. Röll, 2004.

Lewin, Thomas J. Asante Before the British: The Prempean Years, 1975-1900. Lawrence: The Regent Press of Kansas, 1978.

Li, Anshan. "Asafo and Destoolment in Colonial Southern Ghana, 1900-1953." The International Journal of African Historical Studies 28, no. 2 (1995): 327-357.

Linton, Ralph. The Study of Man. New York: Appleton-Century-Crofts, Inc., 1936.

Litowitz, Douglas. "Gramsci, Hegemony and the Law." Brimham Young University Law Review $(1,2000): 515-551$.

Livingston, James C. Anatomy of the Sacred: An Introduction to Religion. 6th ed. Upper Saddle River: Prentice Hall, 2009.

Martí, Gil-Manuel Hernàndez i. "The Deterritorialization of Cultural Heritage in a Globalized Modernity." Journal of Contemporary Culture, no. 1 (2006): 93-107.

Mazrui, Ali A. The African: A Triple Heritage. Boston \& Toronto: Little, Brown and Company, 1986.

Mbembe, Achille. "Ways of Seeing: Beyond the New Nativism. Introduction." African Studies Review 44, no. 2 (August 2001): 1-14. 
Mbiti, John S. African Religions and Philosophy. 2nd ed. Oxford: Heinemann, 1969.

Merry, Sally Engle. Human Rights and Gender Violence: Translating International Law into Local Justice. Chicago and London: The University of Chicago Press, 2006.

Meyerowitz, Eva L. R. At the Court of an African King. London: Faber and Faber Limited, 1962.

—. The Akan of Ghana: Their Ancient Beliefs. London: Faber and Faber Limited,, 1958.

- The Divine Kingship in Ghana and Ancient Egypt. London: Faber and Faber Limited, 1960.

—. The Sacred State of the Akan. London: Faber and Faber Limited, 1951.

Nana Abayie Boaten I. "The Changing Role of Queenmothers in the Akan Polity." Research Review 8, no. 1\&2 (1992): 90-100.

Odotei, Irene K., and Albert K. Awedoba. Chieftaincy in Ghana: Culture, Governance and Development. Sub-Saharan Pub \& Traders, 2006.

Odotei, Irene K. "Women in Male Corridors of Power." In Chieftaincy in Ghana: Culture, Governance and Development, edited by Irene K. Odotei and Albert K. Awedoba. Accra: Sub-Saharan Publishers, 2006.

Opoku, Kofi Asare. West African Traditional Religion. Accra: FEP International Privite Limited $1,1978$.

Owusu, Robert Yaw. Kwame Nkrumah's Liberation Thought: A Paradigm for the Religious Advocacy in Contemporary Ghana. Trenton and Asmara: African World Press, 2006.

Pals, Daniel L. Eight Theories of Religion. Second ed. New York and Oxford: Oxford University Press, 2006.

Parrinder, E. G. "Divine Kingship in West Africa.” Numen 3, no. Fasc. 2 (111AD): Apr., 1956.

Patton, Sharon F. "The Stool and Asante Chieftaincy" 13, no. 1 (October 1979): 74-77+98-99.

Pearse, Meic. The Gods of War: Is Religion the Primary Cause of Violent? Nottingham: IVP Books, 2007.

Perry, Michael. The Idea of Human Rights: Four Inquiries. Oxford: Oxford University Press, 1998.

Prah, Mansah, and Alfred Yeboah. "Tuobodom Chieftaincy Conflict in Ghana: A Review and Analysis of Media Reports." The Journal of Pan African Studies 4, no. 3 (February 2011): 20-33.

Rathbone, Richard. Nkrumah \& Chiefs: Politics Of Chieftaincy In Ghana 1951-1960. First. Athens: Ohio University Press, 2000. 
Rattray, R. S. Ashanti. Oxford: Clarendon Press, 1923.

—. Ashanti Law and Constitution. Oxford: The Clarendon Press, 1929.

- Ashanti Proverb: The Primitive Ethics of a Savage People. London: Oxford University Press, 1916.

- Religion and Art in Ashanti. Oxford: Clarendon Press, 1927.

Raymond Bagulo Bening. Ghana: Regional Boundaries and National Integration. Accra: Ghana Universities Press, 1999.

Richards, Audrey I. "Keeping the King Divine." Proceedings of the Royal Anthropological Institute 6, no. 2 (1968): 23-35.

Rodney, Walter. How Europe Underdeveloped Africa. Revised. Howard University Press, 1981.

Rostow, W.W. The Stages of Economic Growth: A Non-Communist Manifesto. Cambridge: Cambridge University Press, 1960.

Rotberg, Robert I. Christian Missionaries and the Creation of Northern Rhodesia 1880-1924. Princeton: Princeton University Press, 1965.

Rubin, Leslie, and Brain Weinstein. Introduction to African Politics. 2nd ed. New York: Praeger Publishers, 1977.

Ryan, Patrick. "Is It Possible to Construct a Unified History of Religion in West Africa?" Universitas 8 (1984): 98-110.

Sarpong, Peter. Ghana in Retrospect: Some Aspects of Ghanaian Culture. Tema: Ghana Publishing Corporation, 1974.

—. Girl's Nubility Rites in Ashanti. Tema: Ghana Publishing Corporation, 1977.

—. The Sacred Stool of the Akan. Accra: Ghana Publishing Corporation, 1971.

Senghaas, Dieter. The Clash Within Civilizations: Coming to Terms with Cultural Conflicts. London and New York: Routledge, 2002.

Shumway, Rebecca. "The Fante Shrine of Nananom Mpow and the Atlantic Slave Trade in Southern Ghana.” Intemational Joumal of African Historical Studie 44, no. 1 (2011): 2744.

Simensen, Jarle. "Christian Church, 'Native State' and African Culture the Presbyterian Mission in Akyem Abuakwa, Ghana". Special Session on Missions, Modernization, Colonisation and Decolonisation. presented at the 19th International Congress of Historical Sciences, Oslo, July 6, 2000. 
Sittie, Rebecca. "Land Title Registration: The Ghanaian Experience." 1-11. Munich, Germany, 2006.

Stoeltje, Beverly J. "Asante Queenmothers: Precolonial Authority in a Postcolonial Society." Research Review 19, no. 2 (2005): 1-19.

Strinati, Dominic. An Introduction to Theories of Popular Culture. 2nd ed. London: Routledge, 2004.

Sutton, Inez. "Law, Chieftaincy and Conflict Colonial Ghana: The Ada Case." African Affairs 83, no. 330 (1984): 41-62.

Tetteh, Dzifa Emma. "Ghana Needs To Modernize Its Chieftaincy System." The Ghanaian Times. Accra, May 24, 2010.

Tordorff, W. Ashanti Under the Prempehs, 1888-1935. London: Oxford University Press, 1965.

Traer, Robert. Faith in Human Rights: Support in Religious Traditions for a Global Struggle. Washington, D.C: Georgetown University Press, 1991.

Tweneboah, Seth. "Religious Human Rights in the Techiman Traditional Area of Modern Ghana". MPhil Thesis, unpublished: University of Ghana, 2010.

Warren, D. M., and Owusu Brempong. Techiman Traditional State. Vol. 1. 3. Accra: Institute of African Studies, 1979.

White, Lynn. "The Historical Roots of Our Ecologic Crisis." Science 155, no. 3767 (February 10, 1967): 1203-1207.

Williams, Raymond. Marxism and Literature. New York: Oxford U.P., 1977.

Williamson, Sidney George. Akan Religion and the Christian Faith: A Comparative Study of the Impact of Two Religions. Accra: Ghana Universities Press, 1959.

Wiredu, Kwasi. Cultural Universals and Particulars: An African Perspective. Bloomington and Indianapolis: Indiana University Press, 1996.

Yankah, Kwesi. Free Speech in Traditional Society: The Cultural Foundations of Communication in Contemporary Ghana. Accra: Ghana Universities Press, 1998.

- Speaking for the Chief: Okyeame and the Politics of Akan Royal Oratory. Bloomington \& Indianapolis: Indiana University Press, 1995. 